\title{
Variability of physiological responses to exercise
}

Citation for published version (APA):

Kuipers, H. (1983). Variability of physiological responses to exercise. [Doctoral Thesis, Maastricht University]. Vrieseborch. https://doi.org/10.26481/dis.19830610hk

Document status and date:

Published: 01/01/1983

DOI:

10.26481/dis.19830610hk

Document Version:

Publisher's PDF, also known as Version of record

\section{Please check the document version of this publication:}

- A submitted manuscript is the version of the article upon submission and before peer-review. There can be important differences between the submitted version and the official published version of record.

People interested in the research are advised to contact the author for the final version of the publication, or visit the DOI to the publisher's website.

- The final author version and the galley proof are versions of the publication after peer review.

- The final published version features the final layout of the paper including the volume, issue and page numbers.

Link to publication

\footnotetext{
General rights rights.

- You may freely distribute the URL identifying the publication in the public portal. please follow below link for the End User Agreement:

www.umlib.nl/taverne-license

Take down policy

If you believe that this document breaches copyright please contact us at:

repository@maastrichtuniversity.nl

providing details and we will investigate your claim.
}

Copyright and moral rights for the publications made accessible in the public portal are retained by the authors and/or other copyright owners and it is a condition of accessing publications that users recognise and abide by the legal requirements associated with these

- Users may download and print one copy of any publication from the public portal for the purpose of private study or research.

- You may not further distribute the material or use it for any profit-making activity or commercial gain

If the publication is distributed under the terms of Article $25 \mathrm{fa}$ of the Dutch Copyright Act, indicated by the "Taverne" license above, 
Sportwetenschappelijke Onderzoekingen 3

Variability of physiological responses to exercise Harm Kuipers 



\title{
Variability of physiological responses to exercise
}

\section{PROEFSCHRIFT}

ter verkrijging van de graad van

Doctor in de Geneeskunde aan de Rijksuniversiteit Limburg te Maastricht, op gezag van de Rector Magnificus

\author{
Prof. Dr. H. C. Hemker
}

volgens het besluit van het College van Dekanen

in het openbaar te verdedigen in de Aula van de Universiteit op

Vrijdag 10 juni 1983

des namiddags om 16.00 uur

door

\section{HARM KUIPERS}

geboren te Vries

Uitgeverij de Vrieseborch - Haarlem 
Promotor : Prof. Dr. R. S. Reneman

Copromotor: Dr. F. T.J. Verstappen

Referenten : Prof. Dr. R. A. Binkhorst, Katholieke Universiteit Nijmegen Prof. Dr. F. ten Hoor, Rijksuniversiteit Limburg, Maastricht

(c) 1983 Harm Kuipers

Niets uit deze uitgave mag worden verveelvoudigd en/of openbaar gemaakt door middel van druk, fotokopie, microfilm of op welke andere wijze ook zonder voorafgaande schriftelijke toestemming van de uitgever.

BV Uitgeverij De Vrieseborch

Jacobijnestraat 5-2011 TG Haarlem

ISBN $906076188 X$ 
Voon

Marrize

Marthijs Harm

Margaretha Femme

Rae tof Klades 


\section{CONTENTS}

1. GERERAL INTRODUCTION

1.1 Energy metabol ism

1.2 Assessment of Vumax $_{2}$

$1.3 \mathrm{~V}_{2}$ max and athletic performance

1.4 Laboratory tests for estimating physical endurance

1.5 Wariability in athletic perfomance

1.6 Fatigue and performance

1.7 The present study

1.8 Choice of the test protocol

2. MATERIALS AND METHODS

2. 1 Subjects

2.1.1 Subjects for the main study

2.1 .2 Subjects for the study on endurance time

2.2 Test protacol

2. 2.1 Assessment of the mean individual maximal workload in the pre-test period

2.2.2 Regular protocol

2.2.3 Test protocol to study endurance time at a constant workload

2.3 Procedure

2.4 Variables

2.4.1 Heart rate

2.4.2 Respiratory variables: expiratory minute volume $\left(\dot{V}_{E}\right)$, respiratory rate, oxygen uptake $\left(\mathrm{WO}_{2}\right)$, respiratory exchange ratio $(R)$, respiratory equivalent $\left(\dot{W}_{E} / \mathrm{VO}_{2}\right)$

2.4.3 Venous blood lactate concentration

2.4.4 Venous blood $\mathrm{pH}, \mathrm{pCO}_{2}$ and $\mathrm{O}_{2}$ saturation 25

2.4.5 Back-skin and tympanic temperature

2.4.6 Maximal workload attained (Wmax) as measure of performance

2.4.7 Mechanical efficiency 
2.4.9 Rating of subjective feelings before and during exercise

2.5 Data analysis $\quad 27$

2.5.1 Criteria for maximal tests 27

2.5 .2 Data analysis 28

2.5.3 Prediction of $\mathrm{V}_{2}$ max 28

2.5.4 Anaerobic threshold 29

3. ACCURACY OF THE DETERMINATIUN OF THE PHYSIOLUGICAL VARIABLES 31

3.1 Intraduction 31

3.2 Heart rate 31

3.3 Lactate concentration 31

3.4 Measurement of $\mathrm{V}_{2} \quad 32$

3.4.1 Measurement of $\dot{V}_{E}$

3.4.2 Assessment of the concentrations of $\mathrm{O}_{2}$ and $\mathrm{CO}_{2}$ in the expired air 34

3.4.3 Influence of $R$ on $\mathrm{VO}_{2}$ measurements 35

3.4.4 Comments to $\mathrm{VO}_{2}$ measurements 36

3.5 Respiratory rate and respiratory ratio $(R) \quad 36$

$3.6 \mathrm{pH}, \mathrm{O}_{2}$ saturation, $\mathrm{pCO}_{2} \quad 37$

3.7 Tympanic temperature and back-skin temperature 37

3.8 Workload of the bicycle ergometer 37

4. VARIABILITY IN PERFORMANCE 39

4.1 Variability of Wmax and $\mathrm{V}_{2}$ max 39

4.2 Seasonal and menstruational influences on whax 43

4.3 Relationship between whax and physiological variables during increasing workloads 43

4.4 Relationship between physiological variables and relative workload $\quad 44$

4.5 Comments $\quad 44$

5. PHYSIOLUGICAL RESPONSES TO A STANDARD EXERCISE TEST 47

5.1 Heart rate 47

$5.2 \dot{V}_{E}$, respiratory rate and tidal volume 49

5.3 Tympanic and back-skin temperature 52 
5.4 Uxygen saturation and $\mathrm{pCO}_{2}$ in peripheral venous blood

$5.5 \mathrm{Blood} \mathrm{pH}$ and lactate concentration

5.6 Respiratory exchange ratio (R)

$5.7 \mathrm{VO}_{2}$ and its relationship with external workload

5.8 Mechanical efficiency

5.9 Comments

6. EVALUATIUN OF PARAMETERS TO ESTIMATE PHYSICAL ENDURANCE IN THE LABORATORY

6.1 Recovery of heart rate

6.2 The indirect method of Astrand-Rhyming to predict $\mathrm{V}_{2}$ max from submaxinal heart rate

6.3 Anaerabic threshold

6.4 Endurance time at a constant workload

6.5 Comnents

7. fatigue in a subjective anu objective perspective

7.I Relationship between perceived signs of fatigue and physical performance

8. GENERAL DISCUSSION

9. SUMMARY ANO CONCLUSIONS

10. SAMENUATTING EN CONCLUSIES

REFERENCES

TABLES AI-A5 
1. GENERAL INTRODUCTION

\section{I Energy metabolism}

Physiological science exists for several centuries and the functioning of the various argan systens has been studied extensively. These studies generally concerned the body in the resting state. Unly occasionally exercise was used as a model to study the regulation of various organ systems. When athletic activities became more popular and physiologists were confronted with questions from coaches and atnletes, investigations to study the responses of the body to exercise were intensified. These investigations accelerated the development of exercise physiology. In the early days of exercise physiology it were especially scandinavian investigators who extended our knowledge of the body responses to exercise.

To standardize the physical work performed during exercise studies, various types of ergometers and test protocols were developed. The development of ergonetry opened new ways of investigations in the laboratory and the insight into the responses of the body to exercise grew ratner quickly. Uf interest to the physiologists was the maintenance of homeustasis during exercise. Generally accepted concepts had to be revised, since serious disturbances in homeostasis, which were associated with life threatening conditions in patients, had to be considered as normal in healthy people during exercise. For example, a decrease in blood $\mathrm{pH}$ below 7,0 is life threatening in patients, while such values are often observed in athletes after an event of 2 to 4 minutes, without being harmful. Another striking finding in athletes as compared with non-trained people, was their high maximal cardiac output (up to $30-401 . m n^{-1}$ ) and their nigh pulmonary ventilation (up to $2001 . \mathrm{min}^{-1}$ ). To enable the human body to work at nigh intensity, the different organ systems all serve the argan that finally delivers the wark: the muscle. As with increasing workloads the muscle needs more oxygen, ventilation is stimulated and cardiac output is increased to tramsport oxygen. The latter is achieved by an increase in both stroke volume and heart rate. As maximal heart rate is not different in srained and untrained people, athletes' hearts are characterized by a high strake volume, resulting 
in high cardiac outputs. Beside the tmansport of oxygen and carbon dioxide, circulation has to transpont heat to maintain body temperature at a tolerable level. The rise in body cemperature during exercise may be considered as an increase in hypothalamic "set point" temperature rather than a failure of temperature regulation (Nielsen, 1969). These functions of the circulation are facllitated by a change in distribution of cardiac output. While at rest imuscle tissue receives 15-20\% of cardiac output, during exercise this may increase to $80-85 \%$ (Ästrand, 1970 ).

By investigating the orgam systems, especially the cardiorespiratory system, physiologists tried to find an explanation for the athlete's ability to sustain heavy exercise for relatively long periods of time and to increase their energy metabolism about 10 to 20 times the resting value during exercise. The energy delivery has drawn special attention, because in all athletic events with a cyclic character, high energy delivery is an absolute prerequisite for athletic endurance.

The energy needed for muscle contraction is delivered by splitting the energy rich phosphate ATP (for ref Mathews and Fox, 1976). In the resting state the muscle fiber contains a small ATP store, which can be maintained since the ATP used, is resynthesized comtinuously. This is accomplished in different ways. If enough oxygen is avallable the pyruvate, originating from breakdown of glycogen or glucose, enters the mitochondria and is metabolized in the citric acid cycle. The $\mathrm{H}^{+}$ions produced in the citric acid cycle are transported by carriers as NAD and FAD to the "respiratory chain", a series af enzymes (the cytochromes) at the inner surface of the mitochondrial imembrane. Here oxygen is reduced, under formation of water whille the liberated energy is used for ATP resynthesis. In this way, each molecule of glucose deliwers 36 molecules of ATP. The maximum ATP resynthesis rate by this aerobic energy metabolism is 2,2 mmol ATP per $\mathrm{kg}$ dry weignt per second. If the ATP breakdown exceeds aerodic resynthesis capacity, as may be the case in heavy exercise, additional ATP can be formed by the faster process of anderobic breakdown of glucose via pyruvate to lactate. Lactate is formed because not all the $\mathrm{NADH}_{2}$ can be processed by the respiratory chain, so the $\mathrm{H}^{+}$ions are accepted by pyruvate, 
resulting in lactate formation. The ATP resynthesis rate by this so called factic anaerobic energy metabolism is approximately twice the anount obtained by aerobic metabolism. In vigorous exercise, the anderobic lactic metabolism starts imnediately and reaches its maximal ATp resynthesis rate after $15-20$ seconds. The lactate, however, decreases intracellular pH, which is supposed to inhioit glycolysis and the contractile process. Especially events of 10 to 60 seconds duration depend on lactic anaerobic metabolism. If the body has to start vigorous exercise from the resting state, energy for muscle contraction is delivered by splitting the ATP of the limited store, while: quick resynthesis is temporarily met by breakdown of creatine phosphate (CP). This alactic-anaerobic metabolism results in an ATP resymthesis rate, which is 5 to 6 times higher than that of aerobic metabolism. However, the fast breakdown of ATP and CP as well as the limited amounts of these substances leads to depletion within 10 seconds. So only in events like a 100 meter dash, energy metabolism almost exclusively depends on alactic anaerobic metabolism.

Concerning energy delivery, one can distinguish different kinds of physical endurance.

a. Activities which last 1 minute or less depend almost entirely on anaerobic energy delivery and require anaerobic physical endurance

b. Activities which last between 1 and approximately 10 minutes depend almost exclusively on maximal capacity of aerobic energy delivery and require aerobic physical endurance and to a lesser extend anderobic physical endurance.

c. Activities whicn last for a longer period of time depend on aerobic energy delivery. In these activities the athletes are not able to work continuously at maximal aerobic capacity, but at a some what lower level (costill et a 1, 1976). These activities require aerobic physical endurance.

In contrast to anaerobic energy delivery, aerobic energy metabolism can be measured relatively easily in a laboratory situation. By loading an athlete on an ergometer and increasing the workload gradua11y, the oxygen uptake can be measured via the lung ventilation. At a certain point, when the athlete is nearly maximally exerted, the highest oxygen uptake is measured. This highest oxygen uptake measured 
is called maximal axygen uptake $\left(\mathrm{wo}_{2} \max \right)$, aerobic capacity or aerobic power (Astrand and Rodahl, 1970). Because each litter of oxygen taken up is equivalent to about $20,934 \mathrm{~kJ}$, the higher the capacity to consume axygen is, the higher the energy output will be. Therefore, $\mathrm{Vu}_{2} \max$ is considered to be a good paraneter to estimate athletic endurance capacity in events which require nigh aerobic netabolism.

\section{2 Assessment of VO $_{2}$ max}

When using $\mathrm{VO}_{2}$ max as parameter to estimate physical endurance, some problems arise. First of all expensive equipment and skilled personel are required to measure $\dot{V}_{2} \max$ accurately while a $\dot{V}_{2}$ max test itself is time consuming. Another problenl is the definition of "the" $\dot{V}_{0_{2} \text { max }}$ because different kinds of ergometers as well as different test protocals produce a different $\mathrm{V}_{2} 2^{\text {max }}$ value in the same subject.

The type of ergometer is most important and many simple as well as sophisticated ergometers have been used. Althougn for instance climbing stairs, stepping up and down a bench or swimming in a flume may be suitable in certain cases, two tools turned out to be most advantageous: the bicycle ergometer and the treadmill. The treadmili loads the subject in a natural way, as walking and running are familiar to all subjects. The speed of the treadmill can be varied as well as the slope. Drawbacks of treadmill exercise are the more difficult collection of blood, the difficulties encountered in calculating the external load, more difficult auscultation of heart and lungs and the risk of injuries. The bicycle ergometer has the advantage that the subject is sitting, so taking blood, measuring different variables and auscultation of the heart and lungs is relatively easy. Besides, the resistance can be adjusted precisely, so the external load can be calculatea easily and rather accurately. A possible drawback of the bicycle ergometer is that especially in some countries, people are unfamiliar with cycling.

Comparison of the $\mathrm{VO}_{2}$ max values obtained on a bicycle ergometer and a treadmill revealed that the $\dot{V}_{2}$ max as measured on the treadmill generally exceeds the $\mathrm{Vu}_{2}$ max as measured on a bicycle ergometer (Keren et al, 1980). However, it was also reported that trained cyclists could attain the same $\dot{V}_{2}$ max an a bicycle ergometer and on a 
treadnill (Hagerg et al, 1978). This is in keeping with the findings of Verstappen and his colleagues (1982), who reported that in cyclists the $10_{2}$ max was the same when measured on a treadmill and on a bicycle ergoneter, whlle in long distance runners $V_{2}$ max measured on the treanill exceeded $u_{2}$ max measured on the bicycle ergoneter. This seems to agree with the findings of strome and co-workers (1977) who measured $\mathrm{Hu}_{2}$ max in elite skiers, rowers and cyclists both on a treadilil and a bicycle ergometer as well as during the specific athletic actiwity. In all subjects $\mathbf{v o}_{2}$ max was highest during the specific athletic activity. Omly the cyclists attained the same $V_{2}$ max on a bicyclle ergometer. In general, it can be concluded that in untrained people exhaustive walking or running uphill elicits the highest $\dot{10}_{2} \max _{3}$ whereas in trained athletes the highest $\dot{V}_{2}$ max may be obtained on an ergoneter, simulating the specific atnletic activity. So the type of ergometer may be of great importance in measuring the athletes" Vuo ${ }_{2}$ max.

Another factor that affects $10_{2}$ max is the test protocol used. Even when using one type of ergometer and a gradual increase of workload, differences in $V_{2}$ linax can be measured by using different exercise protocols. Prinzen and co-workers (1979) measured vo max on a bicycle ergometer in a number of subjects making use of 3 different test protocols. The first protocol started at 30 watt while the load was increased with 30 watt eacn 3 minutes. In the second protocol the load started at 50 watt whereupon the load was increased each 2 minutes by 50 Watt, but from a heart rate of approximately 160 beats per minute the laad was increased by 25 watt each 2 minutes. In the third protocal the total amount of work performed at each workload was the same. This inplies that the working time at higher loads decreased to less than 1 minute. In the first protocol a significantly nigher $\mathrm{Vu}_{2}$ max was found than in the other protocols with a maximum difference in $v_{2}$ max of $5,2 \%$. Al though in the latter study the third protocol did not produce the highest $\mathrm{VO}_{2}$ max it has also been reported that tests, in whicn the subject is loaded at an intensity which requires anaerobic metabolism, do give higher $V_{2}$ max values than tests with a gradually increasing workload (Knowlton et al, 1977). An additional factor that can influence the $\mathrm{WO}_{2}$ max measured on a bicycle ergometer 
is the rate of revolutian of the paddles. Using higher mevolution rates than the recomended 60 ron (Astrand and Rodahl 1970; Hollmann and Hettinger, 1980) resulted in higher values of Vomax (Eckermann and Millahn, 1967; Herriansen and Saltin, 1969). In a recent review on the influence of revolution rate on Vomax, Poulus and Vos (1982) came to the conclusian that in untrained people a revolution rate of 50 to 70 per minute elicits the highest $\mathbf{V 0}_{2}$ max. In trained people, also in those not accustomed to perform on a bicycle, revolution rates between 80 and 100 per minute resulted in the higest Vu$_{2}$ max values. Un a treadmill the use of an inclination leads to somewhat higher $\mathbf{V O}_{2} \max$ values, than when runining norizontally (Taylor et al 1955, Hemansen and Saltin 1969).

In sumary it can be concluded, that in a laboratory with skilled personel the athlete's $\mathbf{V}_{2}$ max can be determined with in accuracy of $\pm 5 \%$, while the type of ergometer and the protocol used, may influence the measurements. It should be kept in mind that $V_{2}$ max is an indirect parameter of maximal aerooic energy output of the body, which in turn has to be converted into propulsive speed.

\section{$1.3 \dot{v u}, 2$ max and athletic performance}

Not onlly the $V_{2}$ max, but finally the amount of power produced by aerobic metabolism which is converted into propulsive speed, determines the atmletic perfarmance. Verstappen and co-workers (1982) reported tnat at all workloads long distance runners used more oxygen than cyclists when working on a bicyle ergoneter, while on the treadmill cyclists showed a higher oxygen uptake than runners at comparable speeds. This indicates that efficiency of movement is important for atnletic performance too. So, when investigating the relationship between oxygen uptake and external workload, the type of ergometer used to measure $\dot{V}_{2} \max$ is 1 ikely to be of great importance and the efficiency (for definition see section 2.4 .7 ) has to be taken into account.

Ewen if the $\dot{V} u_{2}$ max is measured on an ergometer which has great similarity to the actual athletic activity, using vo,max as a parameter for physical endurance has its limitations. It was reported that in middle and long distance rumers Vo $_{2}$ max did not improve anymore 
after a training perlod, whereas atnletic performance in 800 and 3000 m running did (uaniels et al 1978). Houston and co-investigators (1979) tested 8 well trained runners before and after a two week period of inactivity and again after a two week training period. After the inacivity the $\mathrm{U}_{2}$ max decreased by $4 w_{3}$, while the endurance time at high intensity increased by $25 \%$. After two weeks training, nowever, the $10_{2}$ max was restored again, while the endurance time was decreased. This is in agreament with the observation in speed skaters, whose enhanced skating performance was not reflected in an increased $\mathrm{Vu}_{2}$ max as measured in the laboratory (Enschede, 1960).

Because of the difficulties encountered in the assessment of $V_{2}$ max a discrepancy between vinax and athletic perfomance may occur. Since the amount of power that can be sustained during the athletic activity is of decisive importance it seems worhtwile to consider the maxinal workload that an athlete can attain during a progressive test, as an additional parameter for physical endurance. In this test an ergometer with nigh similarity to the actual athletic activity should be used. Although the validation of the maximal workload attained as parameter for atmletic performance is indicated by the findings in speed skaters, (Geysel, 1976, vam Ingen Schenau 1981) no extensive literature on this subject is available.

\subsection{Laboratory tests for estimating physical endurance}

Because trainers and athers involved in attending athletes want to be informed of the effects of training, a variety of tests to estimate physical endurance has been developed. Because the validity of the various tests was different, a limited number of test methods is used to date. It was found that one of the most valid parameters for aerobic physical endurance is $V_{2}$ max. Although we pointed out that the measurement of $\hat{V O}_{2}$ miax and its use as parameter to assess physical endurance has its limitations, in practice mast tests to evaluate the athlete's physical endurance are based upon the assessment of maximal oxygen uptake. Because accurate measurement of $\dot{V} U_{2}$ max is difficult and expensive, several methods have been developed to predict $\mathbf{V}_{2}$ max or to estimate physical endurance (Vos et al, 1981). Astrand and Rhyming (1954) introduced their well known method to predict $\dot{V}_{2}$ max from heart 
rate values at submaximal exercise. Because prediction of $\mathrm{Vo}_{2}$ max by the method of Astrand and Khyming (1954) is easy to perfom it has become very popular and is widely used. The method is based upon the following assumptions:

a. a linear relation between heart rate and oxygen uptake during exercise. However, this is not always the case (Astrand and Rodahl, 1970).

b. The relationship between heart rate and relative workload is similar in all supjects (Ástrand and Rodahl, 1970). This means that a $70 \% \mathrm{VO}_{2}$ max worklaad of a worla class rumer will elicit the same heart rate as the jogger who al so runs at $70 \%$ of his vomax load, despite the fact that the absolute ladd of the top athlete will be nigher than that of the jogger.

In the original Ástrand-knyming test, the subjects are loaded for 6 minutes at an intensity producing a heart rate between 120 and 170 Deats per minute. The neart rate attained at a known load is supposed to correspond with a certain percentage of $\dot{v} \mathrm{O}_{2}$ max, so maximal $\dot{v O}_{2}$ can be estimated by extrapolation. However, various factors can influence the predicted $\mathrm{VU}_{2}$ max, even when the test is performed under standard conditions. Astrand reported differences between estimated and actual $\mathrm{WU}_{2}$ inax up to 10-15\% while the correlation coefficient between predicted $\dot{V} u$, max and actual $\mathbf{V}_{2}$ max was only 0,78 (Astrand and Rodahl, 1970). Similar correlations between predicted and measured $\mathbf{1 0}_{2}$ max were found by a variety of investigators (Rowell et al, 1964; Glassford et a), 1965; De Vries and Klafs, 1965; Davies, 1968; Jessup et al, 1977; Myles and Toft, 1982; Patton et al, 1982). In general, in trained people $\dot{V} \mathrm{O}_{2}$ max is overestimated while in non-tratned subjects $\dot{V} 0_{2}$ max is underestimated with this method (Astrand and Rodahl, 1970). Thoss and Israel (1975), however, described an overestimation of the ${ }^{*} 0_{2}$ max in untraimed subjects by the Astrand test.

Another disadvantage of the Astrand-Rhyming test is that comparison between laboratories is difficult because of the different results obtained. Factors that may lead to a less accurate estimation of Vu, max, are:

- insufficient control of the test-conditions (Astrand and kodahl, 1970). 
- use of different types of ergometers, which can lead to differences of about st in external work in spite of correct calibration (Binkhorst et al, 1973).

- inadequate calibration of the ergoneter.

It: is assumed that whin the same subject the reproducibility of predicted and measured Wo,max is similar (Binkhorst, 1982). However, differences in predicted Wo max are generdlly interpreted as changes in physical endurance.

Although the Astrand-Rhyming test has the advantage that it is easy to perform and takes 1 ittle time, the test result can be influenced by different factors as discussed before. Estimation of 10,2 max from the linear relationship between external workload and oxygen uptake (Astrand and Modahl, 1970; Hollmann and Hettinger, 1980) may be a possible alternative. If this relation holds, one could estinate vo $2_{2}$ ax by determining the maximal workload that a subject can attain in a progressive test and deduce $\mathrm{Vo}_{2}$ max from this relationship. The use of this method is only allowed if the inter-individual differences are limited and the linear relationship holds for all worklaads. The latter, however, may be questionned. Because it is assumed that the efficiency during cycling is not different for low and nigh workloads (Astrand and Kodahl, 1970), theoreticaliy a linear relation might be expected. However, during heavy exercise additional muscles, like those pulling the handlebars, are activated, while the respiratory inuscles increase their oxygen uptake disproportionally to about 10\% of total oxygen uptake during maximal exercise (Wielsen, 1936; utis, 1964). Besides, the oxygen consumption of the heart increases by about $200 \mathrm{ml.min}{ }^{-1}$. Taking this into consideration, an exponentlal increase in oxygen uptake may be expected. On the other hand it has been reported that the oxygen uptake levels off at higher loads which means that it does not increase anymore with increasing loads (Åstrand and Rhyming, 1970; Hollmann and Hettinger, 1980). Today this levelling off phenomenon is still used as criterion for maximal exertion and having reached $\dot{v}_{2}$ max. Levelling off of oxygen uptake, nowever, has not always been observed by other investigators (Kuipers et al, 1980). It might be that the test protocol itself is responsible for this phe- 
nomenon, because Hollmann and hettinger (1980) reported that levelling off is most commonly found during treadmill exercise, while in bicycle ergoneter tests the subjects had to stop the exercise because of local fatigue before the levelling off phenomenon occured.

Many atnletic activities are performed at a level which is $5-10 \%$ below the $\mathrm{VO}_{2}$ max workload (Hollmamn and Hettinger, 1980). Endurance training hardly improves $\mathbf{W}_{2}$ max although submaximal loads can be sustained for a longer period of time (Gleser and Vogel, 1973; Hollmann and Hettinger, 1980). The latter may be explained by metabolic adaptations, shifting the anaerobic energy delivery to a higher percentage of the $\dot{V} U_{2}$ max workload. This implies that the anaerobic glycoTysis is postponed to a nigher relative workload and hence the rise in blood lactate. This delayed rise in blood lactate concentration is supposed to lead to reduced stimulation of respiration during submaxiInal work (Hollinann, 1961). The workload at which blood lactate as well as expiratory volume show a marked increase, is called aerobicanaerobic transition. In 1964 Wassermann introduced the term anaerobic tnreshold which was defined as the workload in a progressive test at which the expiratory volume $\left(\dot{V}_{\mathbb{E}}\right)$ and expired $\mathrm{CU}_{2}\left(\dot{V} \mathrm{CO}_{2}\right)$ change from a linear to an exponential increase with increasing workloads. Wassermann explained this phenomenon as follows. At low work intensities $\vec{V}_{E}$ and $\dot{V} \mathrm{Cu}_{2}$ show a linear increase with increasing workloads, but when anaerabic metabolism comes into play the formed lactate diffuses to the blaod where it is buffered by bicarbonate. This results in extra $\mathrm{Cu}_{2}$ production, which has a stimulatory effect on respiration, leading to a disproportionate increase in $\dot{V}_{E}$ and $\dot{V}_{\mathrm{CO}_{2}}$. Dawis et al (1976) reported a correlation of 0,95 between the estinated "ventilatory" anderobic tinreshold as defined by wasermann and the rilse in venous blood lactate. Because of this relationship, Mader and co-workers (1976) investigated the lactate kinetics in the peripheral blood during exercise. Because Mader and his collegues empirically established that during increasing exercise blood lactate started to rise exponentially from blood lactate concentrations of 4 mol. $1.1^{-1}$, the workload at which the lactate announted to $4 \mathrm{mmol}^{-1}$ was defined as the anaerobic threshold. Mader stated that in the 1aboratory the specific physical endurance of an atnlete can be estimated by deter- 
mining the worklaad at which the blood lactare amounts to 4 mnol. $\mathrm{I}^{-1}$. He observed that training, resulting in an improvement of atnletic performance, also resulted in an upward shift of the anaerobic threshold. During the last few years, however, conflicting results concerning the anaerobic threshold were published (Rupp, 1981; McLellan et al, 1981). Turner (1981) reported that the "ventilatory" anaerobic threshold and the "lactate" anaerobic threshold could be manipulated independentiy which is not surprising, because the ventilatory response during exercise is not merely regulated by $\mathrm{pH}$ or $\mathrm{C \omega}_{2}$ production. At present no substantial data are available on the reproducibility of anaerobic threshold determimation.

The athletic ability to sustain submaxinal workloads for longer periods of time has not only been approached by measuring the anaerobic threshold. Some investigators have loaded their subjects at a fixed workload and measured the endurance time ( $v$. Reekum, 1974; (Geysel, 1979). Although in the latter study the oberved differences at different occasions were statistically significant, a considerable inter-as well as intra-individual variation was observed. Unfortunately, in the study of Geysel (1979) no relationship between physiological variables and exhaustion was reported, so the physiological load can not be estimated. Neither, an analysis of the variation im endurance time was presented.

A parameter for physical endurance in athletes which is often used by trainers, coaches and athletes, is the recovery of heart rate after exercise. Also in the laboratory the recovery of heart rate has been used to estimate the physical endurance. A variety of indicators which can be calculated from the recovery of heart rate at different time intervals after a given workload, has been used. Although no conclusive references are available, heart rate is supposed to recover the quicker, the better the physical endurance is. In the present study recovery of heart rate was also investigated. 
In summary it can be concluded that the validity of laboratory tests in order to evaluate the physical endurance, is still under debate.

\subsection{Variability in athletic performance}

Variations in athletic performance on a day to day or a week to week basis are well known. The cause of these variations is still incompletely understood. Part of the variability may be explained by differences in external conditions as for instance wind and surface. Besides, it has been assumed that these fiuctuations are of psychological origin. To study variability of physical performance in the laboratory, Katch and co-workers (1982) studied 4 females and 1 male in 8 to 20 successive standard tescs on the treadmill during 2-4 weeks. They observed a variability in $\mathrm{V}_{2}$ max with a coefficient of variation (sd.mean ${ }^{-1} \times 100 \%$ ) between $3,7^{2}$ and $7,3 \%$ while it could be calculated that the coefficient of variation in total running time was 4,1 to $7,8 \%$. Unfortunately no correlation between maximal extermal workload and $V_{2}$ max was reported. Because all tests were considered to be maximal as based upon the maximal heart rates reached and the subjective signs as visual distress and fatigue, Katch concluded that the observed variability in Wo, max and in external workload must be of biological rather than psychological origin. Wright and co-workers (1978) followed two athletes during a 17 week period, in which they were tested week $1 \mathrm{y}$. In these subjects the coefficient of variation in vo 2 max was 5,1 and $6,8 \%$, respectively. No other extensive studies concerning the variability of $\hat{V 0}_{2}$ max or physical endurance are known. It may be questionned, however, whetner the mentioned studies can explain variability in atnletic performance.

Anothem controversial problem concerning variability of physical performance is the influence of the menstrual cycle. Conflicting results with respect to this topic have been reported (for references wilnore, 1973). Hollmann and Hettinger (1980) reported that the postmenstrual cycle periad leads to increased performance, while just prior to and during the menstrual period a decrease in performance could be observed. Jurkowski and collaborators (1981) showed that aerobic pinysical endurance and cardiorespiratary functions are not 
influenced by the phase of the menstrual cycle, in contrast to anaerobic prissical endurance. It was reported that during the luteal phase lactate production as well as anaerobic capacity was improved. Un the other hand Stephenson and co-investigators (1982) could not demonstrate any difference in $\dot{V}_{2}$ max and subjective ratimg of exertion between the various phases of the menstrual cycle.

\subsection{Fatigue and performance}

The term fatigue is used very commonly in daily practice. However, different subjective feelings are expressed by the non-specific term fatigue. It is obvious that the words: "I am tired, fatigued", spoken by an investigator who had a busy day in the laboratory, express quite different feelings than the same words spoken by a cyclist, just after a $200 \mathrm{~km}$ bicycle race. The signals which the subject perceives from the body during heavy exercise as in the test procedure, have the character of discomfort or stress. During an exercise test or an athletic contest a subject has to deal with feelings of discomfort and stress on the one hand and motivational drive on the other. At the very moment that stress and discomfort cannot be counterbalanced by motivation, the subject gives up. Encouragement during competition as well as during the test is meant to increase motivation. To get insight into the perceived exertion, Borg (1962) developed a rating scale for perceived exertion (RPE). This scale includes 15 points, 6 through 20 and its construction was based upon the relationship between heart rate and subjective feelings. If the KPE is multiplied by 10, the heart rate can be approxinated. Borg cautions however that this approximation is a simplification and should not be taken too literally (Borg, 1973). A disadvantage of the Borg scale is that overall heaviness of the workload is scored, while a subject perceives different stressful signals from the body while each of them can cause such a stress that it forces the subject to stop. During heavy exercise breathing can be experienced as stressful, while the working muscles can cause feelings that are interpreted as pain. Another subjective experience is that during heavy exercise the muscle strength seems to decrease, resulting in the inability to maintain the 
required revolution rate. Additionally the working body can produce many undefinable feelings that contribute to the feelings of stress. Some inwestigators have tried to develop scales that differentiate between these sensations (Ekblom and Goldberg, 1971; Simonson and Weiser, 1976). Subjective feelings as expressed by athletes, indicate that different kinds of stress can be performance limiting. On some days pain in the working muscles seems to be dominating, while on others respiratory stress limits performance. A laboratory test can be considered as an athletic perfornance too, because in progressive exercise tests subjects are asked to continue until exhaustion. Although the level of exertion can be objectivated by physiological variables as neart rate, respiratory exchange ratio and lactate level, the moment of stopping the test is a decision made by the subject. To judge whether a subject is really exhausted, most investigators use a number of criterid to be fulfilled. This already indicates that there is no absolute physiological criterion to estimate the exact level of exertion. Generally spoken a subject stops exercise because of fatigue. If the fatigue is so intense that the continuation of exercise is impossible despite utmost efforts of the subject, we may speak of exhaustion.

\subsection{The present study}

As pointed out, the maximal amount of power that a person can produce aerobically and which can be converted into speed, is of final importance for athletic performance. This maximal amount of power can be assessed in the laboratory on a bicycle ergometer and may be considered to be the highest workload a subject can sustain in a progressive exercise test for at least two minutes. Therefore, in bicycle trained people this maximal anount of power (Wmax), expressed in watts, can be considered as a physical performance in the laboratory which is mainly depedent on aerobic physical endurance. This allows to measure physical performance repeatediy in the laboratory setting.

The purpose of the present study is:

a. to evaluate the variability of physical performance and of physiological responses to a standardized test with gradually increasing work lodd. 
b. to investigate the influence of the menstrual cycle upon physical performance and on physiological responses to exercise.

c. to study the relationship between oxygen uptake and external workload to investigate the accuracy of estimating ${ }^{\prime} 0_{2}$ max from Wmax.

d. to evaluate the validity of sone laboratory tests, genrally used to estimate aerobic physical endurance.

e. to study the relationship between physiological variables and subjective perception of fatigue.

\subsection{Choice of the test protocol}

The test protocol should be designed so that the aim of the study could be fulfilled. Besides, each test should provide the data required in a relatively short period of time. However, to investigate the rellationship between external workload and $\dot{V}_{2}$, the organ systems must have the opportunity to adapt to each workload, because the larger a load-increment is, the longer the time needed for adaptations will be. A complicating factor is that the maximal load attained, decreases exponentially with increasing duration of each load (Whipp et a1, 1974). Therefore, we had to compromise on load increment, the time available to each load and the total test duration. Comparison between individuals could be achieved by choosing relative workloads from the prewiously determined maximal workload of the subject.

All these requirements led to a bicycle ergometer test in which each subject started at the sane relative workload, while the load increments consisted of $5 \%$ of the individual maximal workload attained. In this way each test consisted of in the average 7 different workloads with a total duration of about 20 minutes. 



\section{MATERIALS AND METHONS}

\subsection{Subjects}

\subsubsection{Subjects for the main study.}

Eight feniale and 11 male volunteers participated in the study. All subjects were highly motivated and in excellent health. The characteristics of the subjects are listed in table 2.1. The female subjects registered their menstrual cycle. Each cycle was then divided into 4 equal periods, of which the menstrual period was the first. All female subjects had a natural cycle and none of tinem used anticonceptive drugs. The subjects were physically active by regular running and cycling for at least 3 to 5 hours per week, but mone of them competed in races or contests during the experimental periad. Neither the amount of exercise nor the intensity changed significantly during the experimental period. All subjects were non-smokers and did not use any drugs. These subjects followed the regular protocol as described in section 2.2.2.

\subsubsection{Subjects for the study on endurance time.}

A seperate study to evaluate the endurance time at a constant workload as parameter for physical endurance was performed with 10 male subjects. The subjects were in excellent health and 20-31 years old. Three subjects were sedentary, 4 physically active and 3 were well-trained. The characteristics are presented in table 2.2. These subjects performed 4 tests in which they had to work as long as possible on a bicycle ergometer at $80 \%$ of the individual maximal workload attained. The protocol is described in section 2.2.3 
TABLE 2.1 Characteristics of the subjects following the regular protocol

\begin{tabular}{|c|c|c|c|c|c|}
\hline $\begin{array}{l}\text { corde } \\
\text { nr. }\end{array}$ & $\begin{array}{l}\text { age } \\
\text { (years) }\end{array}$ & $\begin{array}{l}\text { body } \\
\text { meight } \\
(\mathrm{kg})\end{array}$ & $\begin{array}{l}\text { mean } \\
\text { test- } \\
\text { Whax } \\
\text { (Watt) }\end{array}$ & $\begin{array}{l}\text { mean } \\
\text { Wogmax } \\
(m f / k g / m i n)\end{array}$ & $\begin{array}{l}\text { number } \\
\text { of } \\
\text { successful } \\
\text { experiments }\end{array}$ \\
\hline
\end{tabular}

PALS

$\begin{array}{rlllll}1 & 32 & 83 & 472 & 70 & 53 \\ 2 & 33 & 68 & 315 & 62 & 71 \\ 7 & 24 & 73 & 228 & 43 & 23 \\ 8 & 28 & 68 & 250 & 52 & 24 \\ 9 & 29 & 75 & 280 & 51 & 26 \\ 10 & 38 & 82 & 270 & 46 & 23 \\ 12 & 25 & 80 & 294 & 50 & 22 \\ 13 & 29 & 84 & 238 & 41 & 27 \\ 14 & 30 & 72 & 231 & 46 & 25 \\ 16 & 35 & 82 & 330 & 55 & 24 \\ 17 & 39 & 74 & 340 & 62 & 19\end{array}$

FEMALES

$\begin{array}{rlllll}3 & 32 & 51 & 200 & 53 & 27 \\ 4 & 25 & 55 & 180 & 46 & 22 \\ 5 & 29 & 59 & 200 & 45 & 18 \\ 6 & 34 & 60 & 150 & 40 & 26 \\ 11 & 27 & 73 & 190 & 41 & 23 \\ 15 & 31 & 64 & 180 & 42 & 14 \\ 18 & 34 & 65 & 228 & 46 & 26 \\ 19 & 23 & 64 & 200 & 50 & 22\end{array}$


TABLE 2.2 Characteristics of the subjects who participated in the endurance test

\begin{tabular}{lccc}
\hline subj. & $\begin{array}{l}\text { age } \\
\text { (years) }\end{array}$ & $\begin{array}{l}\text { body- } \\
\text { weight } \\
(\mathrm{kg})\end{array}$ & $\begin{array}{l}\text { Womax } \\
(\mathrm{m} / \mathrm{kg} / \mathrm{min})\end{array}$ \\
\cline { 2 - 4 } & & & \\
\hline $\mathrm{B}$ & 31 & 71 & 49 \\
$\mathrm{C}$ & 27 & 71 & 58 \\
$\mathrm{E}$ & 22 & 73 & 49 \\
$\mathrm{~F}$ & 26 & 64 & 57 \\
$\mathrm{G}$ & 29 & 83 & 75 \\
$\mathrm{H}$ & 20 & 73 & 62 \\
1 & 27 & 66 & 49 \\
$\mathrm{~J}$ & 22 & 70 & 43 \\
\hline
\end{tabular}

\subsection{Test protocol}

2.2.1 Assessment of the mean individual maximal worklaad in the pre-test period.

To obtain comparable test protocols for all subjects, each protocol was based upon the individual maximal workload attained. Therefore, before the actual experiments started in each subject the maximal workload was assessed 2-3 times in successive tests. Each subject was loaded on a hyperbolic bicycle ergometer (Lode), calibrated at $80 \mathrm{rpm}$. At this $80-r p m$ the subjects started at 100 watt during 5 minutes whereupon each 2 minute the load was increased by 50 Watt. From a neart rate of 160 beats.min ${ }^{-1}$ the load was increased by 25 watt in men and 15 watt in women every $2 \frac{1}{2}$ minute, until the subject had to give up. In each test the maximal workload attained (test-wmax) was defined as the highest workload the subject conpleted and if a workload was not completed, the test-wmax was determined with the following formu1a:

$$
\text { test-Wmax }=W \text { com }+(t / 150 \times \Delta W)
$$


in which Wcom is the last load which the subject completed for $2 \frac{1}{2}$ minutes, $t$ the number of seconds the final, not completed load was sustained, and $\Delta \mathrm{w}$ the final load increment.

\subsubsection{Regular protocol.}

The mean individual maximal workload attained in 2-3 tests (mean test Wmax) was the basis for the regular protocol as used in this study. It consisted of 5 minutes warming up at $70 \%$ of the individual mean test Winax, whereupon each 21 minutes the load was increased by a step which anounted to $5 \%$ of the individual mean test-Wmax. The load was increased until the subject gave up, despite encouragement. The subjects were instructed to keep the pedalling rate constant, between 75 and 85 rpm. After stopping the exercise the subjects had to rest on the bicycle ergometer for $5 \mathrm{~min}$. During the experiment no information was given to the subject about workload and values of the physiological variables.

Before, during and after the test different physiological variables were measured.

2.2.3 Test protocol to study endurance time at a constant workload.

In a separate study the endurance time at a constant workload, $80 \%$ of the individual Wmax, was investigated. To study also the influence of preceding heavy exercise on the endurance time and the physiological variables, two endurance tests were preceded by the test to assess wnax. The study on the endurance time at a constant workload consisted of 4 tests, performed on the bicycle ergometer at one week intervals. In the first test, the subjects started at 100 Watt for 3 minutes whereupon each 3 minutes the load was increased by 50 Watt. From a heart rate of 160 beats.min ${ }^{-1}$, the laad was increased by 25 Watt each 3 minutes, till exhaustion. During the last 30 seconds of each workload blood for lactate analysis was collected from a forearm vein, and heart rate was determined. After exhaustion, the subjects recovered for 10 minutes by easily pedalling at a workload of 75 Watt, whereupon they were loaded again at $80 \%$ of the maximal workload just attained. 
This load had to be executed as long as possible. If a subject sustaned tnis $10 a d$ for 60 minutes the test was teminated. The subjects were externally motivated by encouragements of the experimentator. Every loth minute a blood sample for lactate analysis was collected and heart rate was measured. One week later test 2 was performed. The subject was loaded again without any warming up, at $80 \%$ of the Wmax attained the week before. Again heart rate and blood lactate concentration were measured every 10 minutes. The 3 rd and 4 th test consisted of a repetition of test 1 and test 2 , respectively.

\subsection{Procedure}

After arrival in the laboratory the subject was weighed. A cannula (Butterfly 1y-6-11-10) was inserted into a forearin vein and connected to an infusion system, filled with isotonic saline, to which heparin had been added (250 IU per 10 ml saline). A three-way stopcock was intercalated to collect venous blood samples. Because the first fraction was mixed with saline, the first mi was discarded. After blood collection the system was flushed with saline. Although it might be preferable to use arterial blood, in the present study collection of venous blood was chosen because blood in forearm weins is arterialized during exercise (Yoshida, 1982).

The subject was provided with pregelled ECG electrodes (Conmed) after the skin had been defatted with alcohol. The subject took place on the bicycle ergometer while the saddle and handle bars were positioned so that it was most convenient to the subject. After the subject was comnected to the ECG recorder and breathed via a face mask, the experinent started with the measurements under resting conditions, i.e. sitting on the bicycle ergometer. The room temperature was kept at $20 \pm 1^{\circ} \mathrm{C}$, while the relative numidity was $40-50 \%$. A ventilator was placed in front of the subjects, wich was turned on if wanted by the subject.

To assess statistically significant differences, if any, each subject had to perform a sufficient number of successful experiments. Al thougin the first design consisted of 10 experiments in each subject, during the experimental period the number was increased for statis- 
tical reasons. The subjects who followed the regular protocol generally performed the test between 20 and 25 times during consecutive weeks. In some subjects tests had to be discarded for technical reasons. In practice it turned out that for each subject a period of 9 to 12 months was needed to complete the required number of experiments. unly 2 subjects were able to perforn tests over a period of two years, resulting in a large number of experiments. In these subjects especially seasonal infiuences on the measured physiological variables were investiyated.

\subsection{Variables}

Al1 following variables were determined or calculated for the resting state and the last 30 seconds of each workload. Heart rate was also determined at the 1 st and 5 th minute of the recovery phase.

\subsubsection{Heart rate}

Heart rate was used to trace the circulatory response during exercise and in the recovery period. Heart rate at one ininute after exercise was chosen because this interval is commonly used in tests to estimate physical endurance from the recovery of heart rate. The recovery of heart rate 3 minutes after exercise was found to vary considerably in cyclists (unpublished observation). Because in these cyclists it was indicated that the variation in heart rate was less 5 minutes after exercise, this time interval was also chosen in the present study. The ECG was registered on an 8 channel recorder (Schwarzer) and displayed on a Statscope II-Monitor (BD-Electrodyne). Heart rate was calculated either by hand from the recorded ECG or automatically using the Statscope II (BD-Electrodyne). 
2.4.2 Respiratory variables: expiratory minute volume $\left(\dot{V}_{E}\right)$, respirato ry rate, oxygen uptake $\left(\mathrm{V}_{2}\right)$, respiratory exchange ratio $(R)$, respiratory equivalent $\left(\hat{V}_{E} / \mathrm{V}_{2}\right)$.

The respiratory variables were used to get information about the respiratory and metabolic responses to exercise. The subject breathed via a face mask connected to a low resistance valve system to guide the explratory air flow through a pneumotachograph into a Douglas bag which was used to perform the analysis for $\mathrm{O}_{2}$ and $\mathrm{CO}_{2}$. The temperature of the pneumotachoyraph was controlled by a heating system that maintained the temperature at $37,0 \pm 1,0^{\circ} \mathrm{C}$. (The temperature of the expiratory air was chequed by a thermocouple that was placed directly behind the pneumotachograph). The integrated expiratory volume was recorded on an 8-channel recorder (Schwarzer) and both this volume and the respilratory rate were calculated. The pneumotachograph was calibrated with an air flow calibration set (Godart) before each experiment. The measured $V_{E}$ was corrected far discontinuous flow (section 3.4.1). The recorded expiratory volune consisted of air at $37,0 \pm 1,0^{\circ} \mathrm{C}$, at ambient barometric pressure and was saturated with vapour (BTPS or ATPS conditions). Because callculations were made with air under standard conditions, the expiratory volume in BTPS or ATPS was converted to standard conditions, (STPD) using the equation (Diems and Lentner, 1971)

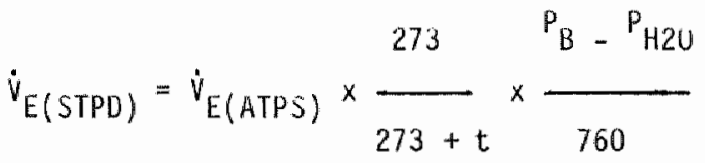

in which $t$ is the temperature $(O C)$ at which $\dot{V}_{E}$ is measured and $P_{H 20}$ the vapour pressure at that temperature, and $P_{B}$ the barometric pressure $(\mathrm{mmitg})$. When $\dot{V}_{E}$ is measured under BTPS conditions, the equation can be written as

$\dot{V}_{E(S T P D)}=\dot{V}_{E(B T P S)} \times 0,8806 \times \frac{P_{B}-47}{760}$ 
A gas sample from the Douglas bag was analyzed for $\mathrm{CO}_{2}$ and $\mathrm{O}_{2}$, using a mass spectrometer (Riber) or using a paramagnetic analyser (Rappox, Godart) for $0_{2}$, and an infrared analyser (Mijnharat) for $\mathrm{Cu}_{2}$. Calibration was done with 2 calibration gases with $\mathrm{O}_{2}$ and $\mathrm{CO}_{2}$ concentrations in the physiological range. The calibration gases were chequed using the scholander method. $\mathrm{VO}_{2}$ was calculated with the following equation (for derivation section 3.4.3).

$\dot{v} u_{2}=\frac{\dot{v}_{E}\left[1-\left(F_{E O 2}+F_{E C O 2}\right)\right]}{0,7903} \times 0,2093-\dot{v}_{E} \times F_{E U 2}$

in which $F_{E U 2}$ and $F_{E C O 2}$ are the fractional concentrations of $O_{2}$ and $\mathrm{CO}_{2}$ in expiratory air, respectively. $\mathrm{VCO}_{2}$ was calculated from

$\dot{V}_{C O}=F_{E C O 2} \cdot \dot{V}_{E}$

The quotient of $\dot{\mathrm{VCO}}_{2}$ and $\mathrm{VO}_{2}$ is usually called respiratory quotient (KO) and reflects the use of substrates metabolized. The latter is based upon the assumption that $\mathbb{R Q}$ reflects $\mathrm{CO}_{2}$ production and $\mathrm{O}_{2}$ consumption at the cellular level. However, many factors can disturb this relationsinip. Therefore, the relationship between expired $\mathrm{CO}_{2}$ and consumed $\mathrm{O}_{2}$ is called respiratory ratio $(R)$, which does not necessarily reflect $\mathrm{O}_{2}$ consumption and $\mathrm{CO}_{2}$ production in relation to substrate metabolism at the cellular level.

R was calcullated by

$$
k=\frac{\dot{v} \mathrm{CO}_{2}}{\dot{\mathrm{v}} \mathrm{O}_{2}}
$$


The respiratory equivalent is the amount of air expired per liter of oxygen taken up and was obtained by dividing $\dot{V}_{E}$ by $\hat{V}_{2}$. It is used as criterion for the level of exertion.

\subsubsection{Venous blood lactace concentration}

Venous blood lactate concentration was considered to reflect the anaerobic contribution to energy metabolism. The blood samples were placed in melting ice and centrifugated afterwards. The serum was analyzed for lactate concentration using an auto-analyzer (Technicon AA2), making use of an enzynatic assay (Bergmeyer, 1974).

\subsubsection{Venous blood $\mathrm{pH}_{3} \mathrm{pCO}_{2}$, and $\mathrm{O}_{2}$ saturation}

Uxygen saturation of the venous blood was assumed to reflect the degree of arterialisation. The $\mathrm{pH}$ and $\mathrm{pCO}_{2}$ were used as indicators of the acid-base balance of the body. During blood sampling one ml was drawn into a heparin coated syringe and analyzed with the aid of a blood-gas analyser (ABL-2, Radiometer, Copenhagen) which was calibrated automatically every 4 hours.

\subsubsection{Back-skin and tympanic temperature}

Back-skin and tympanic temperature were used to study the thermal response to exercise. Although generally mean skin temperature is used, as computated from temperature readings at different sites, for technical reasons we only measured skin temperature at one location. A cemperature probe (EIlab DU-3) based upon the therno-couple principle was fixed with tape to the subject's back-skin between the scapulae. This place was chosen because the back-skin temperature was found to give the most reproducible readings.

Another temperature probe (Ellab DU-3) was fixed in the auditory canal, against the tympanic membrame. In this way back-skin temperature and tympanic temperature could be measured simultaneously during the experiment. The tympanic temperature was used because it is con- 
sidered to represent core temperature and responds more rapidly to changes in core temperature than rectal temperature.

2.4.5 Maximal workload attained (max) as measure of perfonance

The maxinal workload attained (Wmax) was considered to be the hignest work load the subject sustained for at least 2 minutes. Wnax was considered to be a test performance.

\subsubsection{Mechanical efficiency}

Gross mechanical efficiency, as calculated from oxygen uptake, is assumed to reflect the efficiency of cycling. Because working for 1 minute at 1 watt $(60 \mathrm{~W} . \mathrm{s})$ is equivalent to $60 \mathrm{~J}$ and because each liter of oxygen used is equivalent to approximately 20934 Jowles the mechanical efficiency (ME) $(\%)$ can be approximated by:

$$
M E=\frac{60 \times W}{20934 \times \hat{V O}_{2}} \times 100 \%
$$

in which $W$ is the load in watt, and $\dot{v}_{2}$ the actual oxygen uptake (1. $\left.\min ^{-1}\right)$.

2.4.8 Relative workload.

To be able to compare workloads between as well as within individuals, the workloads in each test were normalized by converting the absolute workloads to relative workloads. This was done by expressing the wurklaads of each test as percentage of the wmax value attained in the corresponding test. 
2.4.9 Kating of subjective feelings before and during exercise

To get insight into the feelings that force the subjects to stop the exercise, they were asked to score the different physical feelings at the moment they gave up. The rating scale consisted of points from 0 -10 in which 0 means no special sensation at all and 10 the most heavy sensation.

The subjective feelings to be scored were:

a. general fatigue

b. respiratory stress

c. heat stress

d. sensations of pain in the working unuscles

e. loss of muscle strength

Because of our interest in the predictability of physical work capacity from subjective feelings before the test, the subjects were asked to predict the maximal workload that could be attained. Since we had the impression that the potential test performance could be estimated better during light exercise than in the resting state, the same question was asked after the 5 th minute of the warming-up period at $70 \%$ Wmax. The predictive Wmax was compared with the actual Wmax.

For the prediction of Whax and the rating of the subjective feelings at the moment of exhaustion, the first 5 tests were used to accustom the subjects to the procedure. Therefore, the first 5 tests were discarded for the ultimate analysis.

\subsection{Data analysis}

\subsubsection{Criteria for maximal tests}

Unly tests which were considered to be maximal efforts were used in the study. To decide whether a test could be considered as maximal, the following criteria, of which 4 out of 6 had to be fulfilled, were used: 
1. a lactate concentration in the blood of at least 8 minol. $1^{-1}$ (Hol) mann and Hettinger, 1980; Astrand and Rodam, 1970).

2 . a heart rate value within the $99 \%$ confidence interval of the individual heart rate at maximal workloads.

3. a respiratory equivalent $\left(\vec{V}_{E} / w_{2}\right)$ above 30 (Hollimann and Hettinger. 1980).

4. an $\mathrm{R}$ value $\left(\mathrm{VCO}_{2} / \mathrm{VO}_{2}\right)$ over 1,00 (Binkhorst, 1963).

5. a respiratory rate within the $99 \%$ confidence interval of the maximal individual respiratory rate.

6. the investigator"s judgement of the subject's distress.

2.5.2 Data analysis

All data were stored on tape and analyzed with the aid of a computer (VAX). Data analysis was executed by making use of the Biomedical computer Program (BiMUP-package, Dixon and Brown 1979). The relationship between external workload and oxygen uptake was evaluated with regression analysis. To evaluate differences in variables between groups for statistical significance the data were analyzed with an F-test for equality and a multiple paired t-test.

Graphical reproduction of variables was perforned making use of techniques of exploratory data analysis as described by Tukey (1977). For some purposes the experiments of each subject were yrouped according to the different Whax walues that each subject scored during the experiment. Differences between the variables in these groups of experiments were analysed for statisticali significance, making use of techniques described by Lindly and Snith (1972) and Fearn (1975). Differences were considered to be statistically significant at $\mathrm{p}<0,05$.

\subsubsection{Prediction of $\dot{v}_{2} \max$}

Prediction of maximal oxygen uptake was perforned using the heart rate attained at the end of the first 5 minutes warming up period at a workload which was $70 \%$ of the mean test-wmax. From the heart rate attained at this workioad, the $\dot{V}_{2}$ max was predicted with the Astrand nomogranil for the prediction of $\dot{\mathrm{V}}_{2}$ max (Astrand and Rodah1, 1970). 
Because in the same test the maximal heart rate attained was also determined, the predicted $10_{2}$ max was corrected for maximal heart rate (Ästrand and Rodaht, 1970).

\subsubsection{Anaerobic threshold.}

The amaerobic threshold (the load at which the blood lactate concentration anounted to $4 \mathrm{mmol} .1^{-1}$ ) was determined by plotting the lactate concentration as a function of external workload, making use of a smoothing technique described by Tukey (1977). The line that connected the means and $95 \%$ probability intervals was drawn. The laad, at which the mean lactate level amounted to 4 mmol. $1^{-1}$ could be interpolated and was considered to be the anaerobic thresnold. 

3. ACCURACY OF THE DETERMINATION OF THE PHYSIOLOGICAL VARIABLES

\section{1 introduction}

To be able to decide whether small changes in the variables measured are of physiological significance, one has to be informed of the accuracy of the methods used to measure the vartables.

To express the accuracy or precision of the method used to measure a wariable, generally the correlation coefficient between the measured and true values is used. In general a calibration value is known which is considered to be the true value. By comparing the measured and calibrated values, systematic errors, if any, can be revealed, prowided that the calibration value is the "true" value. In case the true value is unknown, no direct information about the accuracy of the method can be obtained. In this case the accuracy of the method can be estimated by assessing the reproducibility of duplicate measurements. The reproducibility can be expressed by the correlation between the duplicate measurements or the $99 \%$ confidence interval of repeated measurements.

\subsection{Heart rate}

The ECG was recorded during 30 seconds at rest and during the last 30 seconds of each workload. Heart rate was calculated from the ECG recording over 10 beats. By calcullating heart rate at various intervals from the ECG recurding, for duplicate calculcations, correlation coefficients of 0,992 and 0,998 were obtained, for heart rate values in the range of $140-150$ beats.min ${ }^{-1}(n=30)$ and $180-190$ beats.min ${ }^{-1}$ $(n=30)$, espectively.

\subsection{Lactate concentration}

The lactate analyser was calibrated with a number of solutions containing low and high lactate concentrations $\left(0,50-20,0\right.$ mmol. $\left.1^{-1}\right)$. This procedure was repeated each day. The correlation between "true" and 
measured values was 0,996 in the low $(n=30)$ as well as the high range $(n=30)$. This high accuracy of the method is supported by the $99 \%$ confidence interval of the measured values at a true concentration of 2,00 mimol. $11^{-1}$, being 1,88 to 2,12 mol. $1^{-1}$. At a true concentration of 15,00 mmol. $^{-1}$, the $99 \%$ confidence interval was 14,81 to 15,19 mol. $1^{-1}$. The measurements in blood were always done in duplicate resulting in a correlation coefficient of 0,994 . The high accuracy of blood lactate measurements means that even small changes in blood lactate concentration can be determined accurately provided that the sampling procedure is correct.

\subsection{Measurement of $\mathrm{VO}_{2}$}

Determination of $\dot{V} u_{2}$ at a given workload shows an inter-as well as intra-individual variation. (The maximal difference in $\mathrm{VO}_{2}$ at a submaxilnal workload of $70 \%$ Wmax was $0,6551$. min $^{-1}$ between subjects while the intra-individual difference at this workload was maximally 0,349 1.min ${ }^{-1}$ ). One part of this variability may be biological in origin while the other part may be due to errors, made in the assessment of $\mathrm{VO}_{2}$. Because true $\mathrm{VO}_{2}$ is unknown one has to estimate the accuracy of assessing $\mathrm{V}_{2}$ by determining the accuracy of the methods used to measure the variables from which $\dot{V}_{2}$ is computated. $\dot{V O}_{2}$ was calculated from the following equation:

$$
\dot{V}_{2}=\dot{V}_{I} \cdot F_{I O 2}-\dot{V}_{E} \cdot F_{E U 2}
$$

To be able to solve this equation, the following variables have to be measured or calcullated:

a. the volume of air as exhaled per minute $\left(\dot{V}_{E}\right)$

b. the fractional concentration of oxygen in the inspired $\left(F_{102}\right)$ and expired air $\left(F_{\text {EUZ }}\right)$

c. the inspiratory volume of air as inhaled per min. $\left(\dot{V}_{1}\right)$, which can be calculated (section 3.4.3) 


\subsubsection{Measurement of $\dot{V}_{\mathrm{E}}$}

The expiratory volume $\left(\dot{V}_{E}\right)$ was measured by a pneumotachograpin (Godart), making use of a Fleischhead-3 (Fleisch, 1956). Calibration was performed by a spironeter with constant flow. The volume displacement coulld be varied from 10 to $6001 . \mathrm{min}^{-1}$. The spirometer was attached to the Fleisch head of the pneumotachograph and the signal was registered on a recorder (schwarzer). It turned out that the response of the Fleisch nead was linear up to flows of $4501 . \mathrm{min}^{-1}$ after which a deviation occurred. To simulate physiological breathing, which is characterized by discontinuous flow patterns, a calibration pump with known vollume displacement was constructed. This calibration pump was attached to the fleisch head and discontinuous volume displacements, varying from 10 to $2001 . \mathrm{min}^{-1}$ were applied. The expiratory volumes as calculated from the recordings, were compared with the true expiratory volume of the pump. Above volumes of approximately $1201 . \mathrm{min}^{-1}$ the calculated $\dot{V}_{E}$ was less than the true volume. It turned out that this discrepancy varied with changing tidal volume and frequency, so the use of a single correction factor was not permitted. Graphs at various frequencies and tidal volumes were constructed to correct for discontinuous flow. The discrepancy could also be demonstrated by comparing the expiratory volume as calculated from the recording and from the volume in the Douglas bag as measured by a calibrated gas volumemeter.

The $99 \%$ confidence interval was 58,2 to 61,8 for a true $\dot{V}_{E}$ of 60 $1 . \mathrm{min}^{-1}$ and 143,1 to 156,9 for a true $\dot{V}_{E}$ of $1501 . \mathrm{min}^{-1}$.

A source of error in assessing $\dot{V}_{E}$ can be caused by leakage of face mask and tubes. Hence, before each test possible leakage was tested by closing the expiratory circult at the inlet to the Douglas bag, while the subject was asked to expire forcefully. So leakage, if any, as a source of error can be assumed to be negligible. 
3.4.2 Assessment of the concentrations of $\mathrm{O}_{2}$ and $\mathrm{CO}_{2}$ in the expired air

Because a number of subjects was tested on one day and each subject filled 7 to 10 Douglas bags, quick analysis was necessary. So the Haldane and Scholander method were, though accurate, not adequate. Therefore, the gas analysis was performed either with a mass-spectrometer (Kiber) or with a paramagnetic $0_{2}$ analyser (Rapox, Godart) and an infrared $\mathrm{CO}_{2}$ analyser (Mijnhardt). The mass spectrometer as well as the paramagnetic $\mathrm{O}_{2}$ analyser and infrared $\mathrm{CU}_{2}$ analyser were cal ibrated with fresh air and calibration gases with $\mathrm{CO}_{2}$ and $\mathrm{O}_{2}$ concentrations in the physiological range. The calibration gases and room air were analyzed at regular intervals with the micro Scholander technique. The correlation coefficient for $\mathrm{O}_{2}$ between measured and true value on the paramagnetic analyser varied from 0,992 to 0,994 for true concentrations of $20,93 \%(n=30)$ and $15,83 \%(n=30)$, respectively. The correlation coefficient for $\mathrm{CO}_{2}$ on the infrared $\mathrm{CO}_{2}$ analyser varied from 0,991 to 0,995 for true concentrations of $0,03 \%,(n=30)$ and $4,65 \%$ $(n=30)$, respectively. For the mass spectrometer a correlation coefficient of 0,992 between measured and true values for $\mathrm{O}_{2}$ concentrations of $20,93 \%(n=30)$ as well as $15,83 \%(n=30)$ was obtained. For $\mathrm{CO}_{2}$ a correlation of 0,993 was obtained for a $\mathrm{CO}_{2}$ concentration of $0,03 \%$ $(n=30)$ and $4,65 \%(n=30)$. Duplicate measurements from the same Douglas bag, but with 30 minutes in between, resulted in a slight increase in $\mathrm{O}_{2}(1-2 \%)$ and a small decrease in $\mathrm{CO}_{2}$ concentration $(1-2 \%)$.

In some experiments in which the mass spectroneter was used for $\mathrm{O}_{2}$ and $\mathrm{CO}_{2}$ analysis exceptional values for $\mathrm{VO}_{2}$ and $\mathrm{R}$ were obtained. It turned out that choking of the imlet system and instability of the vacuum system could cause erroneous $\mathrm{CO}_{2}$ and $\mathrm{O}_{2}$ values. Therefore, vallues that were beyond the $99 \%$ confidence interval of the corresponding relative workl aad were excluded for further analysis. 
3.4.3 Influence of $\mathrm{K}$ on $\mathrm{VO}_{2}$ measurements

If the respiratory exchange ratio is unequal to 1,00 the inspiratory and expiratory valumes are not equal. In case of $\mathrm{R} \ll 1$ a volume of $\mathrm{CO}_{2}$ is added to the expired air which is smaller than the volume of $\mathrm{O}_{2}$ taken up from the inspired air. So in this situation $\dot{V}_{E}\left\langle\dot{V}_{I}\right.$. If on the other hand $R>1$ as during heavy exercise, more $\mathrm{CO}_{2}$ is added to the expired airr, than $0_{2}$ is taken up from the inspired air, so $\dot{V}_{E}>\dot{V}_{I}$. Because nitrogen is inert and it is assumed that no nitrogen is taken up or added to the air, $F_{I N 2}=F_{E N 2 *}$ Then

$$
\begin{aligned}
& \dot{v}_{I}\left(F_{I N 2}\right)=\dot{v}_{E}\left(F_{E N 2}\right) \\
& \dot{v}_{I}=\dot{v}_{E} \frac{F_{E N 2}}{F_{I N 2}}
\end{aligned}
$$

In the expiratory air

$$
F_{E N 2}=1-\left(F_{E 02}+F_{E C U 2}\right)
$$

If fresh air is inspired $F_{\text {IN2 }}=0,7903$

and $F_{102}=0,2093$. Then equation 3.1 can be written as

$$
\dot{v}_{2}=\frac{\dot{v}_{E}\left[1-\left(F_{E 02}+F_{E C U 2}\right)\right]}{0,7903} \times 0,2093-\dot{v}_{E} \cdot F_{E 02}
$$

In case $R$ equals 1,00 equation (3.5) can be reduced to

$$
\dot{v}_{2}=\dot{V}_{\mathrm{E}}\left(F_{102}-F_{E U 2}\right)
$$

By neglecting differences in $\dot{V}_{E}$ and $\dot{V}_{I}$ due to $R$ values below or above 1,00 , an error is made in the assessment of $\dot{v}_{2}$. By neglecting this so called Haldane correction during light exercise with a $R$ value below 
1,00, a too low $\dot{V}_{2}$ value is obtained, while at the final stage of loading, with a $R$ value above 1,00 , a too high vio, value is calculated. Croonen and Binkhorst (1974) measured $\mathrm{VO}_{2}$ at different $R$ values and calculated the difference between the $\mathrm{VO}_{2}$ as deternined with and without correction for $\dot{V}_{E}$ in relation to $R$. At lower loads and in the resting state the error made by neglecting the effect of $k$ upon $\dot{V}_{2}$ approximates $3 \%$. At the highest workloads the error is $0-2 \%$. In the present study corrections for $\dot{V}_{E}$ were made by applying the Haldane factor. However, occasional problems with the mass spectrometer resulted in possible errors in assessing R. Hence the possible error, resulting from the effect of $R$ on $\dot{V}_{E}$ measurements will be less than $2 \%$.

3.4.4 Comments to $\dot{V}_{2}$ measurements

The accuracy of assessing $\dot{V} u_{2}$ in the present study as estimated from the accuracy of the methods used to measure the variables from which $\mathrm{Vu}_{2}$ is calculated, is $\pm 4 \%$. Astrand and kodahl (1970), nowever estimated the accuracy of assessing $\mathrm{VO}_{2}$ to be less than $3 \%$, while they reported a total variability in $\dot{v}_{2}$ max of $3 \%$, including biolological variations. In the present study total variability in ${ }^{*} 0_{2}$ max was found to be more than $3 \%$. The coefficient of variation of $\mathrm{V}_{2}$ max varied between $4,20 \%$ to $11,35 \%$ from individual to individual (mean $7,58 \%)$. These results are comparable to those reported by Moncrieff (1968), who compared $\dot{V}_{2} \max$ measurements in the same subject as presented by a variety of investigators.

\subsection{Respiratory rate and respiratory ratio (R)}

Respiratory rate was determined from the ventilation patterns as recorded with the pneumotachograph and the values during the last minute of each workload were counted. A correlation coefficient of 0,998 was found for duplicate countings in the range from 20-30 respirations.min ${ }^{-1}(n=20)$.

Duplicate measurements of $R$ from the same Douglas bag resulted in a 
correlation coefficient of 0,991 .

\section{$3.6 \mathrm{pH}_{2} \mathrm{O}_{2}$-saturation, $\mathrm{pCO}_{2}$}

The blood gas analyser (ABL3, Radiometer, Copenhagen) was calibrated automatically 4 times a day while errors in calibration were reported. In the manual, provided by the manufacturer, the accuracy is reported to be very high for all measurements. For $\mathrm{pH}$, at true values between 6,99 and 7,64 , the $99 \%$ confidence interval is $\pm 0,002$. The $99 \%$ confidence interval for $\mathrm{pCO}_{2}$ is $\pm 0,06 \mathrm{kP}$. The $99 \%$ confidence interval for oxygen saturation is $\pm 3 \%$.

\subsection{Tympanic temperature and back-skin temperature}

The electrodes for the measurement of tympanic and skin temperature were compared with a calibrated mercury thermometer in water of different temperatures between 25 and $40^{\circ} \mathrm{C}$. The correlation coefficient between the temperature readings of the electrodes and that of the mercury thermometer was 0,991 for both electrodes. Tympanic temperature was also compared with rectal temperature. Tympanic temperature showed a systelllatic lower value as compared with rectal temperature with a mean difference of $0,19^{\circ} \mathrm{C}$ (range $0,02-0,41^{\circ} \mathrm{C}$ ). A correlation coefficient of 0,92 between rectal and tympanic temperature was calculated under resting conditions. At a true rectal temperature of $37,0^{\circ} \mathrm{C}$, the $99 \%$ confidence interval of tympanic temperature was 36,0 to $37,2{ }^{\circ} \mathrm{C}$.

\subsection{Work load of the bicycle ergometer}

The bicycle ergoneter was electrically braked while the resistance was independent of revolution rate within certain limits. Because our subjects had to maintain a constant revolution rate between 75 and 85 rpm, the ergoneter was calibrated once per year at revolution rates of 70,80 and $90 \mathrm{rpm}$. For revolution rates between 70 and $90 \mathrm{rpm}$ the difference between indicated and real loads was \pm 5 Watt. It was found that the calibration did not change over a one year period. By com- 
paring during calibration the indicated load with the real load, a correlation coefficient of 0,99 was obtained for rewolution rates between 70 and $90 \mathrm{rpm}$. 


\section{VAKLABILITY IM PERFORMANCE}

4.1 Variability of Wmax and 10,2 max

All subjects attdined different maximal workloads. (Wmax) on different occasions. Some subjects scored 3 distinct wnax values, while others attained 4 or even more different wax values (table 4.11 ).

TABLE 4.1 Maximal workloads attained (Watts) and number of times this load was reached (in parentheses)

subject

$n r$.

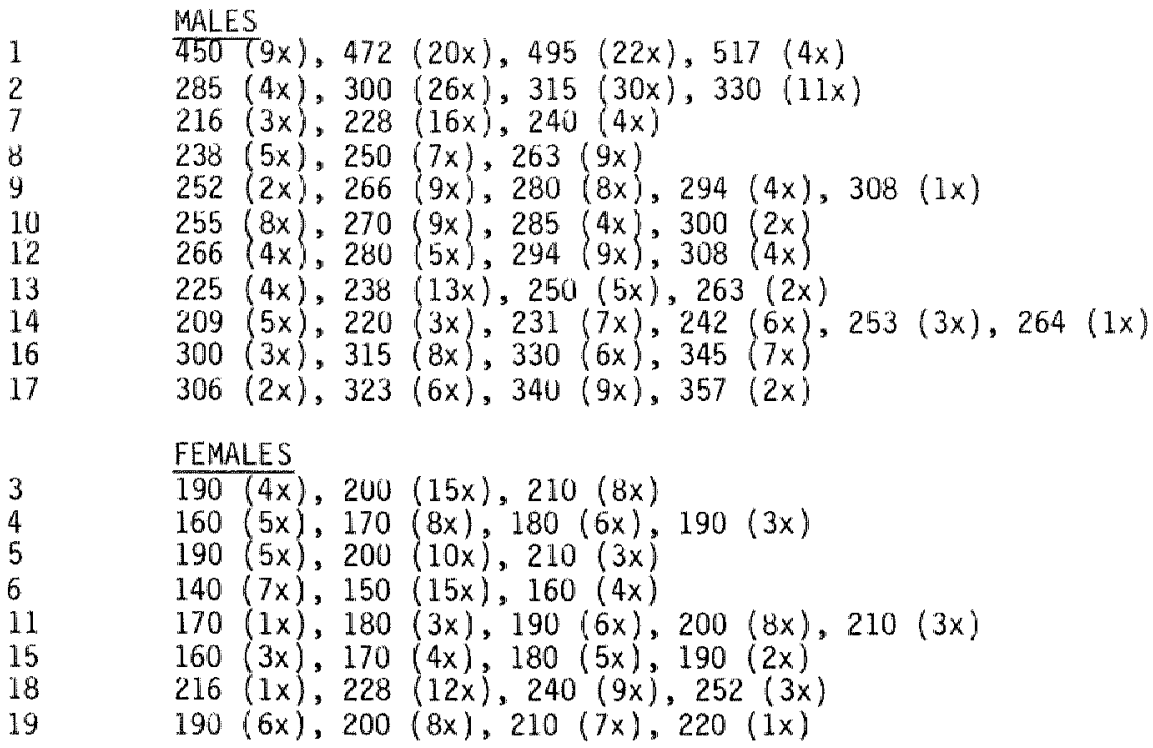

The coefficient of variation in whax attained, as listed in table Al, varied inter-individually between 2,95 and $6,83 \%$ (mean 4,79\%). No difference in variability could be observed between male and female subjects. Neither a relationship between variability and absolute whax or Whax per $\mathrm{kg}$ body weight was found. (In the test population the correlation coefficient between the individual coefficient of variation in whax and the individual mean whax was 0,23$)$. In all subjects the variability in $\mathrm{Vu}_{2}$ max exceeded that of wax (table $\mathrm{Al}_{1}$ ). The coef- 
ficient of variation in $\mathbf{V}_{2}$ max varied inter-individually between 4,20 and $11,35 \%$ (mean $7,58 \%$ ). The correlation between the mean individual $\mathrm{VO}_{2}$ max and the indiwidual coefficient of variation in $\mathrm{VO}_{2}$ max was $-0,50$. The variation in $\mathrm{WO}_{2} \max$ was not related to the variation in wmax. As shown in figure 4.1 a discrepancy between whax and $v_{2}$ max may occur although a gross relationship between these two variables existed. The correlation coefficient between $\dot{V}_{2}$ max and wax varied inter-individually from 0,12 to 0,51 .

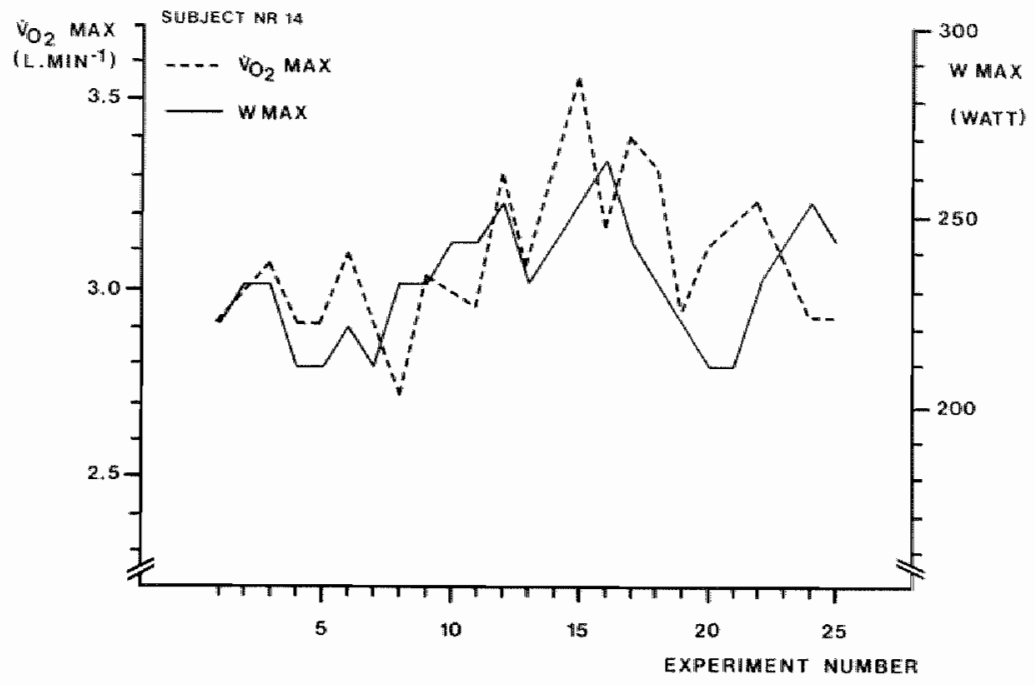

figure 4.1

Wmax and 0, max as determined in different teste rexpemment number) in o ${ }^{2}$ aubject. Between test 10 to 20 (jume-august) a tendency to an increased $\mathrm{WO}_{2}$ max and $\mathrm{w}$ max can be seen. 


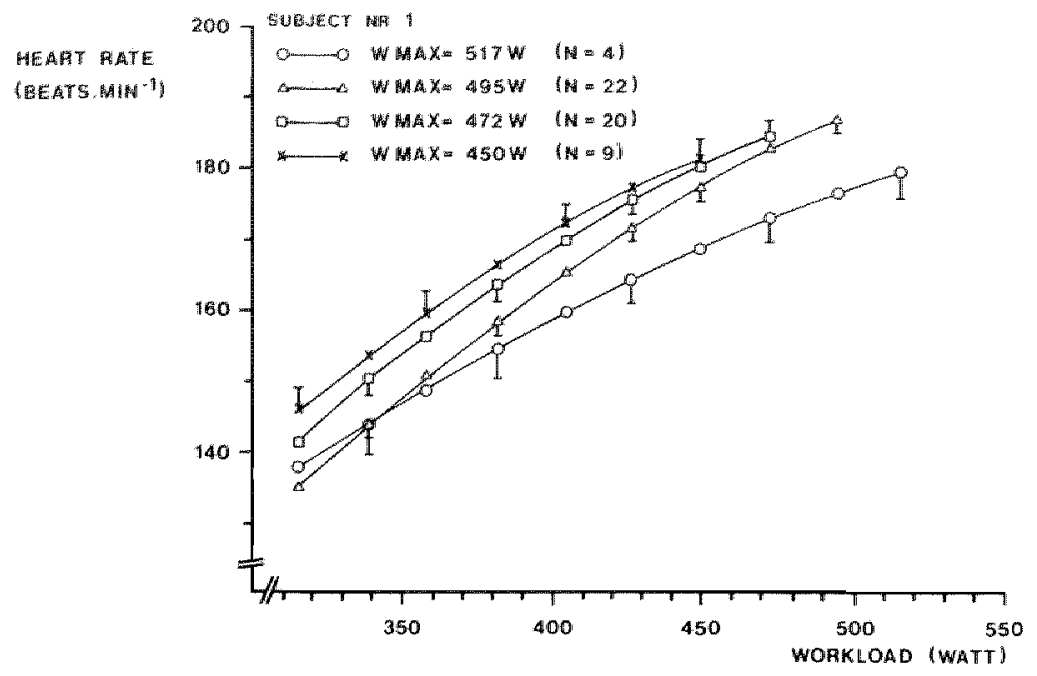

figume 4.2

Retationship between heart mate and extemal workload. The experiments are grouped according to the Wmax attained. The melationship between mean heart nate and extemal workload is shown per group. The bars represent the standard deviation.

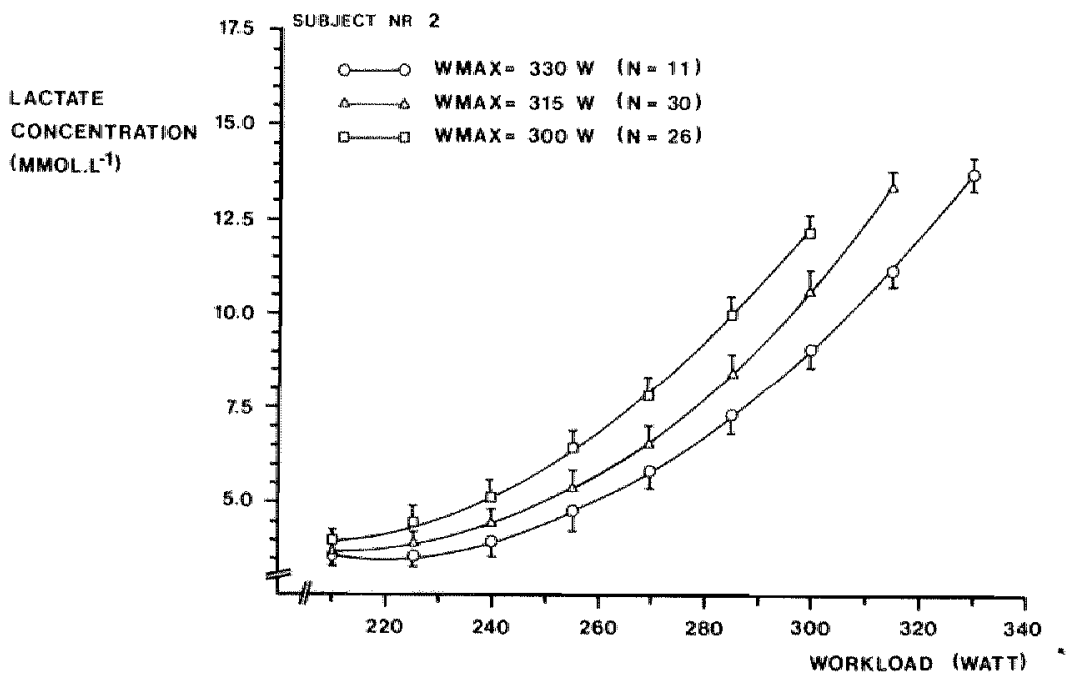

figure 4.3

Relationship between blood lactate concentration and workload. The experimente ane grouped according to the Whax attained. The bars represent the standard deviation. 


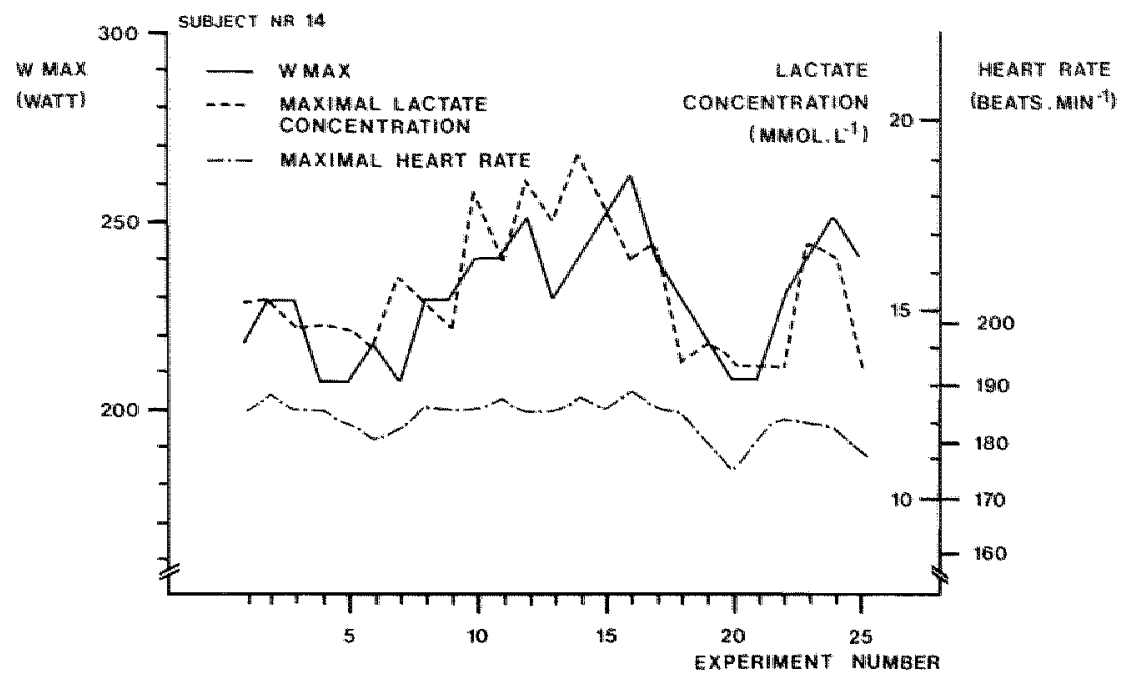

figume 4.4

Whax, maximal heart rate and maximal blood lactate concentration attained, as detemined in different tests (experment number) in one subject.

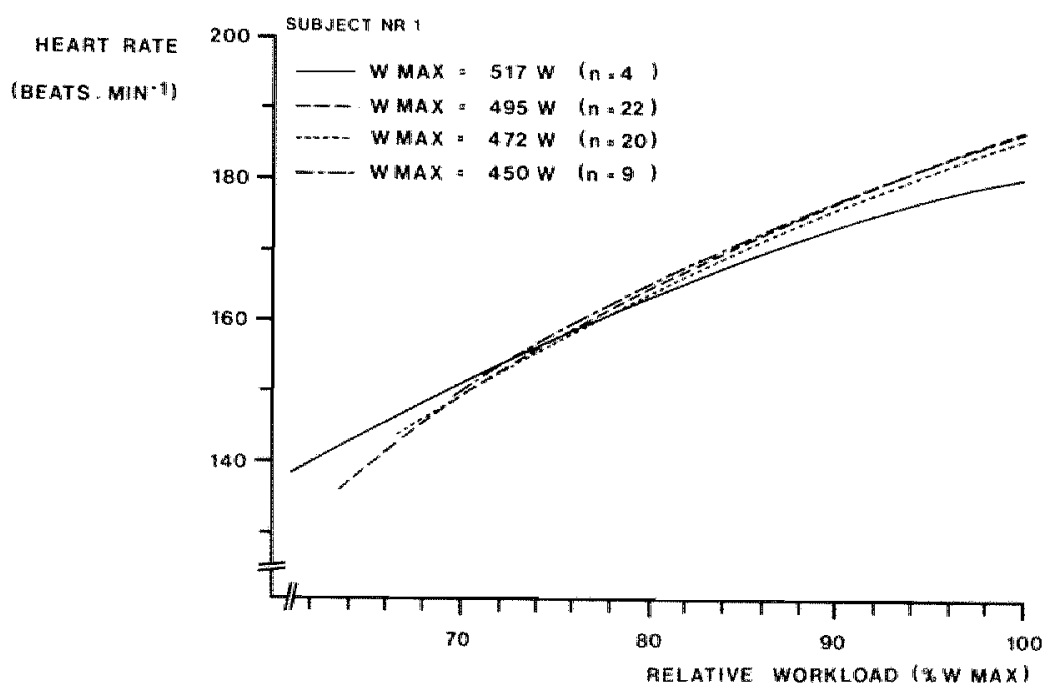

figure 4.5

Relationahip between heart rate and relative workiad. The experiments are grouped according to hmax attained. Per group mean heart rate is plotted as a function of relative warkload. The data in this figure refer to those represented in figure 4.2 . 


\subsection{Seasonal and menstruational influences on winax}

Evaluation of the whax values as function of time, did not reveal a seasonal pattern. Only in 2 male subjects a certain pattern in whax seemed to occur (figure 4.1). In all other subjects wax waried randonly.

In the 8 female volunteers no significant differences were found between the Wrax values attained in the 4 periods of the menstrual cycle in any of the subjects. The same holds for the physiolagical responses as a function of relative worklaads.

4.3 Relationship between Wimax and physiological variables during increasing workloads

By plotting the mean curve and $95 \%$ confidence band of the various physiological variables as a function of external workload, after grouping the experiments in each subject according to the wmax attained, the following results were obtained. At higher Wmax attained, heart rate, expiratory volume, respiratory rate, blood lactate concentration and oxygen uptake were lower at all workloads, resulting in a shift of these curves to the right. The opposite, a shift of the curves to the left, was found when lower whax values were reached (figures 4.2 and 4.3 for heart rate and blood lactate concentration, respectively). The observed shift of the mean curves to the left or the right, were significant $(p<0,05)$ for heart rate in all subjects, while for $\dot{V}_{E}$ and respiratory rate the shift was statistically significant in 13 subjects and non-significant $(0,05<p<0,10)$ in 6 subjects. The shift of the mean curve of blood lactate concentration was statistically significant in 10 subjects, while a non-significant difference was observed in 9 subjects $(0,05<p<0,10$ in 6 and $p>0,10$ in 3 subjects). The differences in $\dot{V}_{2}$ at submaximal workloads between groups with different hmax levels were statistically significant in 3 subjects, while a non-significant difference was observed in 16 subjects $(0,05<p<0,10$ in 8 and $p>0,10$ in the other 8 subjects).

Mechanical efficiency as calculated from oxygen uptake at $70 \%$ Wmax tended to be increased when higher Wmax values were attained, while 
the opposite was found at lower Mnax values. The differences were statistically significant in 3 and non-significant in the other subjects $(0,05<p<0,10$ in 8 subjects and $p>0,10$ in 8 other volunteers $)$. No significant shift of the mean curve with changes in whax could be found in the other physiological variables, when plotted as a function of external workload.

A pure shift of the variables to the left or the right in relation to whax attained, would implicate that the maximal values of the variables concerned are the same, but reached at a different workload. However, in some of the subjects the maximal values of some variables turned out to be different at different wax values (table $A_{2}$ ). Heart rate, expiratory volume, respiratory rate, ${ }^{0} 0_{2}$ max and lactate concentration tended to be increased at higher whax levels in some subjects while blood pH showed a tendency to decrease at higher hnax values. The observed differences were statistically significant in only a few cases (tabie A2). Within one subject, a difference in the maximal value of a variable was not necessarilly assaciated with a difference in another one (figure 4.4 and table A2).

4. 4 Relationship between physiolagical variables and relative workload

In each subject the test protocol consisted of the same external workloads while only the highest worklaads could be different, depending an Wmax attained. Because of differences in wmax values between tests, the absolute workloads can be different in a relative sense (section 2.4.8). By platting the various physiological variables as a function of relative workload and by grouping the experiments in eacn subject according to the wax attained, the differences as described in section 4.3 and shown in figure 4.2 disappeared (figure 4.5$)$. So the magnitude of the physiological responses to exercise are related to the relative workload.

\subsection{Comments}

The results of the present study show that wax and $\mathrm{vo}_{2}$ max attained, vary in all subjects. The variability in whax and $\mathbb{V}_{2}$ max is unrelated 
to sex or the absolute level of whax and $\dot{\mathrm{V}}_{2}$ max. The variation in $\mathrm{VO}_{2}$ max exceeds that in whax, while differences in whax are not always associated with proportional changes in $W_{2}$ max.

The varlability in $\mathrm{VO}_{2}$ max as found in the present study is comparable with the variability in $\dot{V} u_{2} \max$ as reported by other investigators (Wright et al, 1978; Katch et al, 1982). The latter investigators concluded that the variability in $\dot{V}_{2}$ max was biological in origin. Unfortunately in the study of Katch and co-investigators the relation between changes in maximal external workload attained and changes in W0, max were not explicitly evaluated. Fron the present study it cannot be cancluded whether the variation in $\mathrm{VO}_{2} \max$ and the discrepancy between changes in whax and $\mathfrak{V O}_{2}$ rnax reflect a biological phenomenon or that they result from errors made in the assessment of $\dot{\mathrm{V}}_{2}$ max.

The shift of the physiological variables in relation to whax attained (figures 4.2 and 4.5 ), indicates that the variation in wmax on a week to week basis is mainly caused by biological factors. This is supported by the finding that the shift disappears when the physiological variables are plotted as a function of relative workload. This indicates that the inagnitude of the physiological responses to exercise depend on the relative workload. This implicates that within one subject a certain relative workload is always associated with values of a physiological variable within narrow limits.

In some subjects there was a tendency that an increase in whax attained was associated with an increase in the maximal values of heart rate, $\dot{V}_{E}$, respiratory rate, blood lactate concentration and $\dot{V} u_{2}$ max. A difference in a certain variable was not necessarily associated with a difference in other variables within the same subject. It should be realized, however, that the duration of the experiments increased when wnax reached higher values.

No seasonal influences on wimax could be observed in any af the subjects. In 2 subjects, however, a certain rhythmical change in whax was observed. These subjects had been suffering from injuries for a couple of weeks. Which decreased their amount of exercise drastically. This was reflected in a decrease in Wax, which gradually restored to the pre-injury level as the amount of exercise was increased again.

In the present study no influence of the menstrual cycle on per- 
formance could be snown. This is in agreement with the results reported by Jurkowski and co-workers (1981). However, the results are not in keeping with the findings reported by Hollmann and Hettinger (1980). These authors reported a decrease in performance just prior to and during the menstrual phase. 
5. PHYSIOLOGICAL RESPONSES TO A STANDARO EXERCISE TEST

\subsection{Heart rate}

Heart rate generally increased with increasing workload in a nearly linear way. In some subjects the heart rate tended to level off at nigher worklodds. This tendency to level off was not consistent and sometimes was only observed in some of the experiments witnin one subject. By expressing heart rate at a given workload as percentage of the maximal heart rate attained, relative heart rate values were obtained. By comparing mean relative heart rate at a relative workload of $70 \%$ wnax, it was found that some of the female subjects reached relative heart rates which were silightly higher $(86-89 \%)$ than those observed in most of the subjects ( $80 \%$ in the average) (tablle 5.1 ).

Heart rate at a given submaximal warkload showed a standard deviation varying between individuals from 4 to 6 beats.min ${ }^{-1}$. Figure 5.1 illustrates the relationship between submaximal heart rate at a given workload and the Wmax attained. Although in general higher Wmax values were associated with lower heart rate values at the end of the first workload, discrepancies were found frequently. By plotting heart rate as a function of relative workload, the variation in heart rate at all loads was diminished, with a standard deviation varying between individuals from 3 to 4 beats.min ${ }^{-1}$. Mean maximal heart rate varied interindividually from 179 to 190 beats.min ${ }^{-1}$. Within each subject maximal neart rate showed a variability with a standard deviation varying between individuals fram 3 to 5 beats.min ${ }^{-1}$. No significant correlation was found between individual mean maximal heart rate and age. 


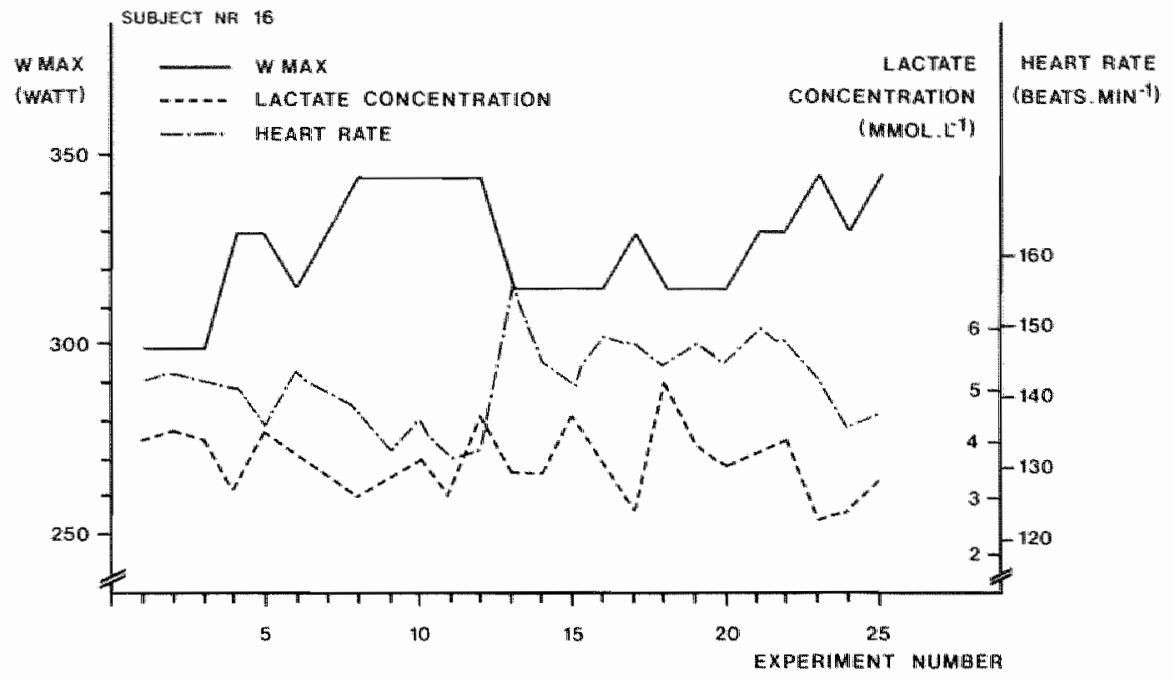

figure 5.1

Wmax, heart mate and blood lactate concentration after 5 minutes of exercise at the lowest workload $(210 \mathrm{~h})$ as detemined in different tests (experiment number) in one subject.

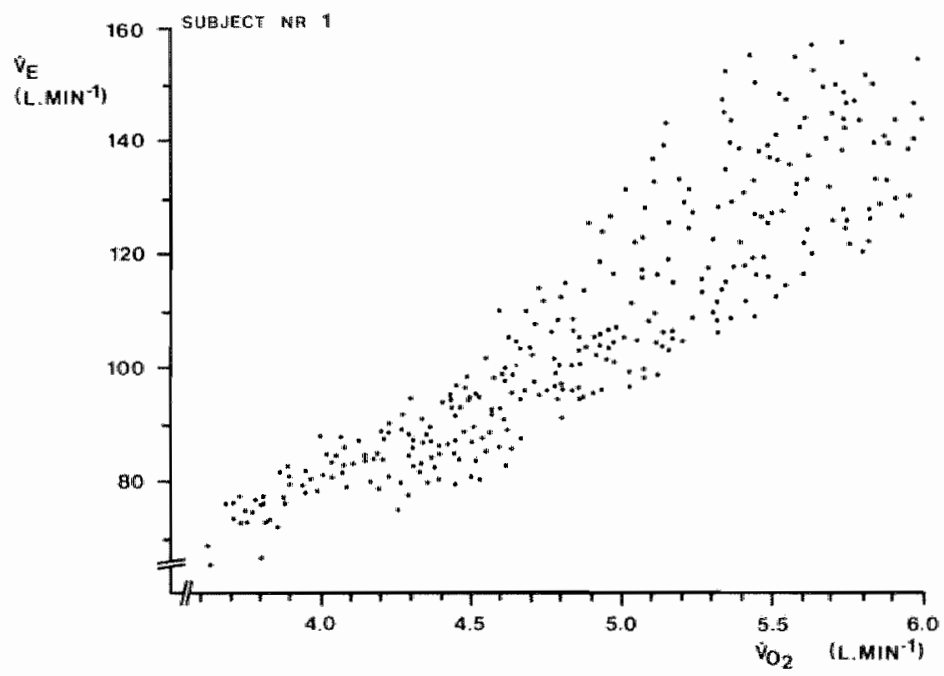

figume 5.2

The relationship between $V_{E}$ (STPD) and $\forall O_{2}$ in one subject. 
Table 5.1

Age, mean relative heart rate at $70 \%$ of maximal workload and mean maximal heart rate of the male and female subjects. Means \pm sd are presented.

$\begin{array}{llll}\text { subject } & \text { age } & \text { mean rela- } & \text { mean maximal } \\ n r . & \text { (yrs) } & \text { tive heart } & \text { heart rate } \\ & \text { rate at } & \text { (beats.min } & \text { ) } \\ & 70 \% \text { wax } & \end{array}$

MALES

$\begin{array}{llll}1 & 32 & 83 \% \pm 5 & 179 \pm 5 \\ 2 & 33 & 78 \% \pm 4 & 180 \pm 3 \\ 7 & 24 & 81 \% \pm 4 & 190 \pm 3 \\ 8 & 28 & 82 \% \pm 4 & 183 \pm 5 \\ 9 & 29 & 80 \% \pm 4 & 184 \pm 5 \\ 10 & 38 & 81 \% \pm 5 & 184 \pm 5 \\ 12 & 25 & 82 \% \pm 3 & 188 \pm 3 \\ 13 & 29 & 78 \% \pm 4 & 180 \pm 5 \\ 14 & 30 & 85 \% \pm 3 & 184 \pm 3 \\ 16 & 35 & 83 \% \pm 5 & 180 \pm 5 \\ 17 & 39 & 79 \% \pm 3 & 181 \pm 3\end{array}$

FEMALES

$\begin{array}{llll}3 & 32 & 88 \% \pm 3 & 185 \pm 3 \\ 4 & 25 & 82 \% \pm 3 & 185 \pm 4 \\ 5 & 29 & 86 \% \pm 4 & 186 \pm 5 \\ 6 & 34 & 84 \% \pm 3 & 183 \pm 3 \\ 11 & 27 & 89 \% \pm 3 & 185 \pm 3 \\ 15 & 31 & 82 \% \pm 4 & 183 \pm 3 \\ 18 & 34 & 88 \% \pm 3 & 184 \pm 3 \\ 19 & 23 & 80 \% \pm 5 & 180 \pm 5\end{array}$

\section{$5.2 \dot{v}_{E}$, respiratory rate and tidal valume}

Figure 5.2 shows an example of the relationship between $\dot{V}_{E}$ and oxygen uptake. The relationship between these variables is somewhat curvilinear, 111 ustrating that in general at higher $\dot{v}_{2}$ values ventillation may increase disproportionally. The increase in $V_{E}$ is the result of increased respiratory rate and tidal volume. Tidal volume increased with increasing workloads, but from a load of about 60 to $70 \%$ of the 


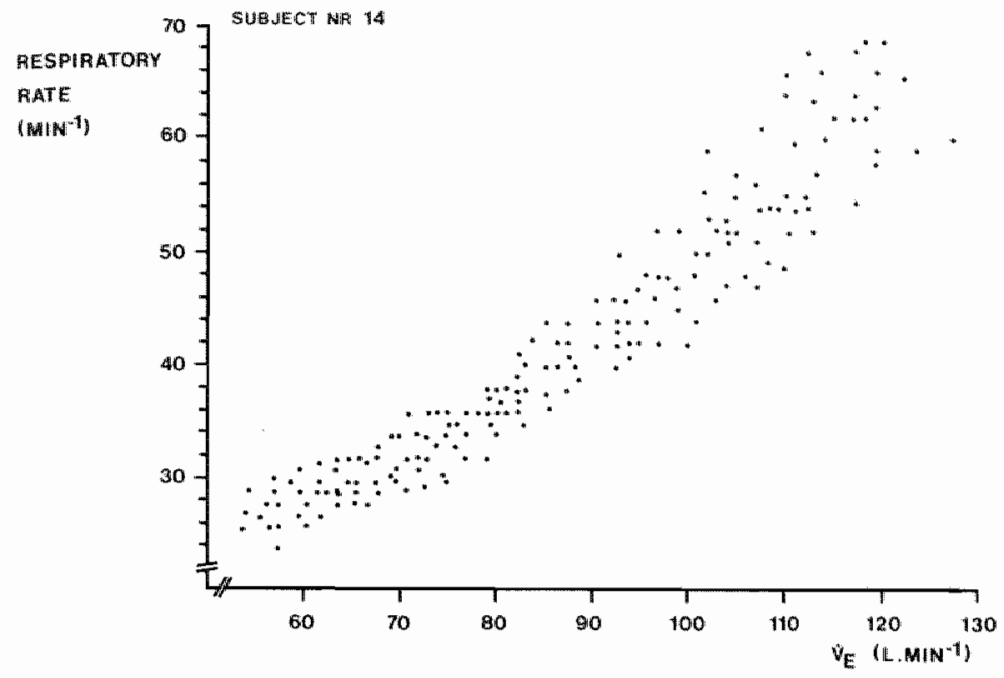

figure 5.3 The relationship between respiratory rate and $V_{E}$ (STPD) in one
subject.

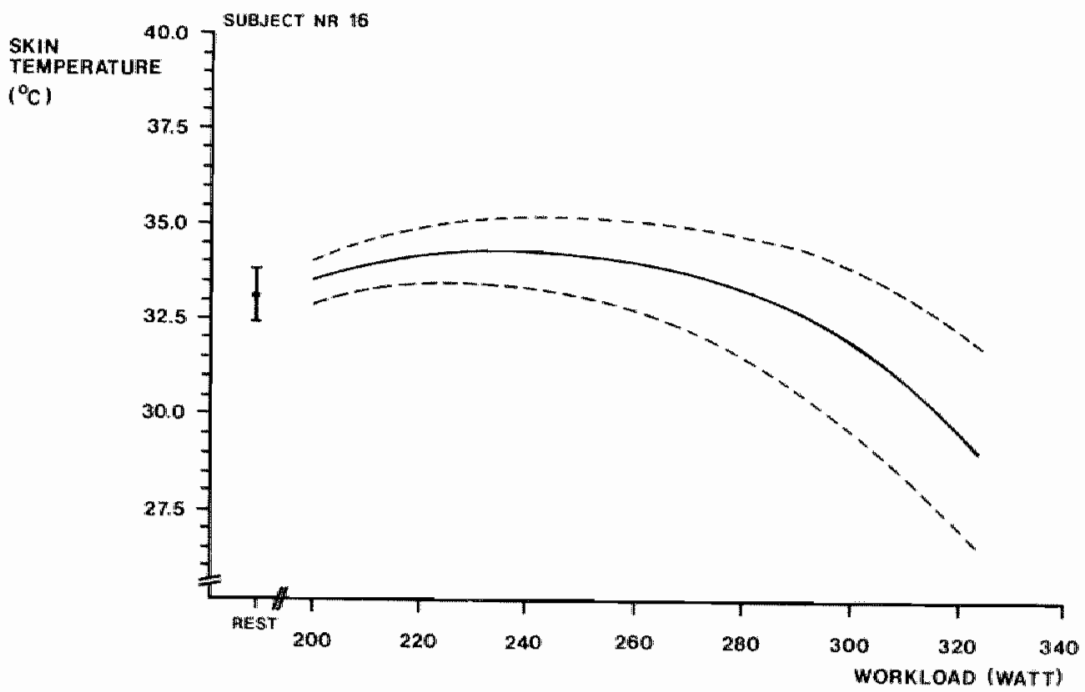

figure 5.4

Mean back skin temperature with $95 \%$ confidence limits as function of external workload of all measurements in one subject. $(n=16)$ 


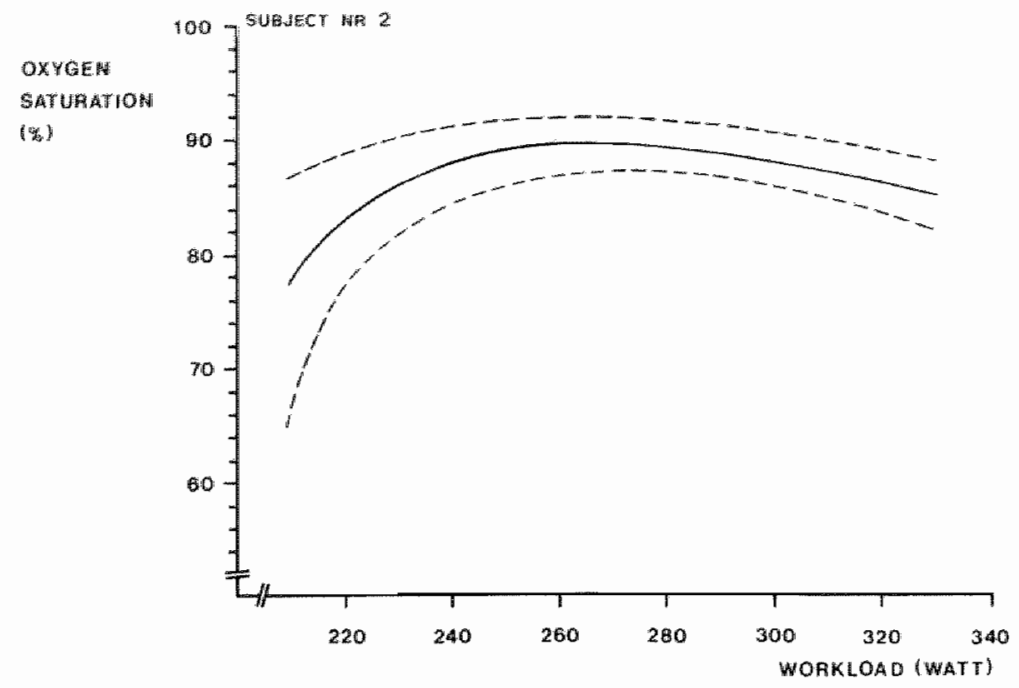

figure 5.5

Mean venous axygen saturation with $95 \%$ confidence limits as function of external workload in one subject. ( $n=52)$

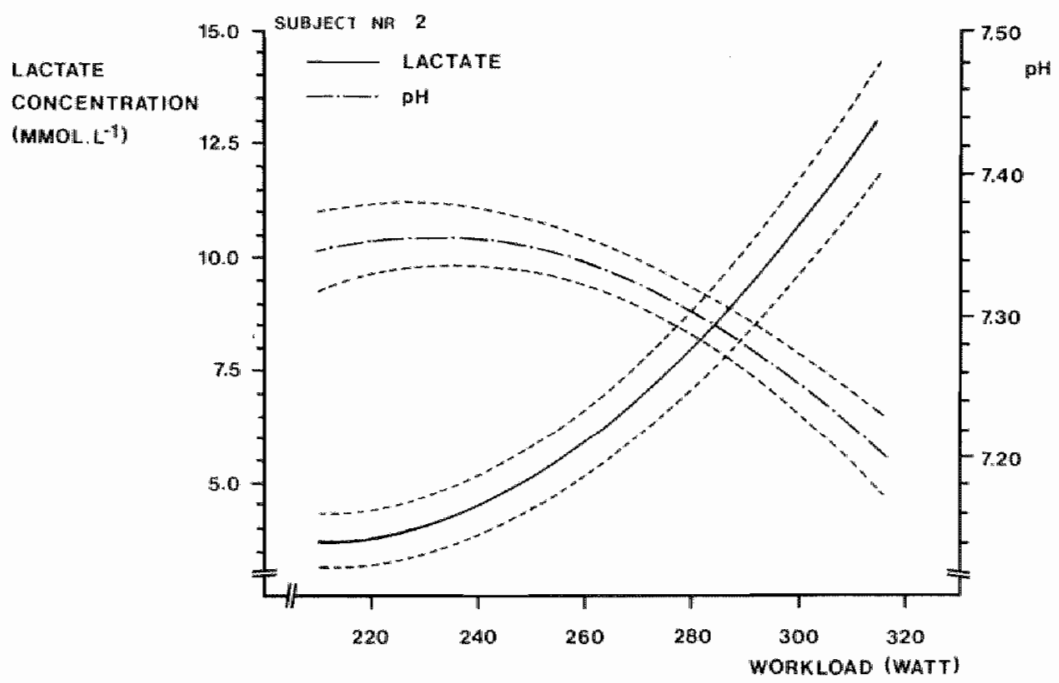

figure 5.6

Mean vertous blood lactate concentration and $\mathrm{pH}$ with $95 \%$ confidence limits as function of extermal workload ower alt mectsuremente in one subject. ( $n=52)$ 
Whax, the increase in $\dot{V}_{E}$ was mainiy caused by an increase in respiratory rate as shown in figure 5.3. In some cases tidal vol ume decreased slightly during very heavy exercise, while respiratory rate increased disproportionally. Maximal $\dot{V}_{E}$ showed a variability with a standard deviation varying between individuals from 3 to 10 iiters.min ${ }^{-1}$. The variation in $\dot{V}_{E}$ was less at lower workloads. At $70 \%$ wnax the standard deviation in $\dot{V}_{E}$ varied intra-individually from 2,5 to 7,01 .min ${ }^{-1}$. In all subjects respiratory rate varied at given workloads. The standard deviation varied between individuals from 2 to 4 respirations.min ${ }^{-1}$ at all workloads. The mean maximal respiratory rate varied inter-individually from 34 to 59 respirations.$m^{-1}$ (mean 46 ).

\subsection{Tympanic and back-skin temperature}

Wean tympanic temperature of the test population rose from $36,0 \pm 0,3^{\circ} \mathrm{C}$ at rest to $37,4 \pm 0,3^{\circ} \mathrm{C}$ (mean $\pm s d$ ) during maximal exercise, despite the fact that the absolute workloads were different. By plotting the tympanic temperature as a function of relative workload, all subjects showed a similar rise in tympanic temperature. This indicates that the rise in core temperature is related to relative workload. In the female subjects no difference in tympanic temperature response was found between the periods of the menstrual cycle. The variation in tympanic temperature was about the same at rest and during exercise. The standard deviation varied from 0,3 to $0,4^{\circ} \mathrm{C}$ between individuals.

At rest the mean back-skin temperature of the test population was $33,2 \pm 0,8^{\circ} \mathrm{C}$ (mean $\pm s d$ ). During exercise in all subjects a slight inital increase in back-skin temperature was followed by a pronounced fall in this variable to in the average $29,2 \pm 0,8^{\circ} \mathrm{C}$ (figure 5.4 ). In about $20 \%$ of the experiments, temperature registration was incomplete or had to be discarded due to loosening or dislacation of the electrodes.

The variation in back-skin temperature was smaller at low than at nigh workloads. The standard deviation varied inter-individually from 0,6 to $0,9^{\circ} \mathrm{C}$ at the lower workloads and from 1,1 to $2,2^{\circ} \mathrm{C}$ at high workloads. The response of the mean back-skin temperature was similar for a11 subjects, which indicates that the temperature response of the back-skin is related to relative workload. 
5.4 Uxygen saturation and $\mathrm{pco}_{2}$ in peripheral venous blood

Figure 5.5 snows a typical example of the relationship between extemal workload and oxygen saturation in venous blood. After 5 minutes at the lowest workload, the venous oxygen saturation showed a marked variation, while at increasing workloads in all subjects saturation rose to near arterial values. In some subjects the venous saturation occasionally decreased at near maximal workloads. In some subjects this decrease in venous axygen saturation was observed rather often, whlle in others this phenomenon was seen only occasionally. No relationship between the occurrence of this drop in oxygen saturation and the level of Hmax attained was found.

Venous $\mathrm{pCO}_{2}$ generally showed a gradual decline at increasing workloads. At maximal workloads, values varying from 4,5 to $5,3 \mathrm{kPa}$ were found. The variation in $\mathrm{pCO}_{2}$ showed a standard deviation varying between individuals from 0,3 to $0,5 \mathrm{kPa}$ at all workloads.

\subsection{Blood $\mathrm{pH}$ and lactate concentration}

A typical example of the venous blood $\mathrm{pH}$ and lactate concentration, both as a function of external worklaad, is shown in figure 5.6. While the lactate concentration increased exponentially at increasing workloads, $\mathrm{pH}$ showed an exponential decrease. Considerable differences in naximal blaod lactate concentration were found between the subjects. The mean maximall lactate concentration varied inter-individually from 7,44 to 15,76 mol. $1^{-1}$. No relationship between maximal lactate concentration and the level of whax was found. When the blood lactate concentration at 70\% Wmax was expressed as percentage of the maximal lactate concentration attained, marked differences were faund. The mean relative blood lactate concentration at a relative workload of 70\% Wmax varied between individuals from 23 to $45 \%$ (mean $33 \pm 6 \%$ ). A non-significant correlation $(r=0,26)$ was found between the relative lactate concentration at $70 \%$ wmax and the relative heart rate at $70 \%$ Whax and between the relative lactate concentration at $70 \%$ Wmax and absalute thax $(r=0,58)$.

The intra-individual variation in blood lactate concentration at 
Inaximal workloads exceeded that at low workloads. At low workloads the standard deviation waried between indiwiduals from 0,5 to 1,2 monol. $1^{-1}$, while at maximal workloads the standard deviation varied between 1,0 and 2,5 monol. $1^{-1}$. By plotting the blood lactate concentrations in each individual as a function of relative workload, the standard deviation decreased to values varying inter-individually from 0,2 to 0,6 mmol. $1^{-1}$ only at low workloads. At high workloads the variation did not change.

\subsection{Respiratory exchange ratio $(R)$}

During the increasing exercise test k gradually increased from about 0,80 to 0,90 during light exercise to values near or over 1,00 during maximal exercise. At $70 \%$ of wnax mean $R$ showed a maximal difference of 0,12 between individuals. At maximal workloads the maximal interindividual difference in mean $R$ decreased to 0,07 . The intra-individual variation in $R$ at low workloads as well as high workloads had a standard deviation varying from 0,01 to 0,05 between individuals.

\section{$5.7 \dot{\mathrm{VO}}_{2}$ and its relationship with external workload}

Figure 0.7 shows the relationship between oxygen uptake and external workload. The relationship between these variables was approximately linear in all subjects and could be characterized by the following general regression equation:

$$
\mathrm{VO}_{2}=0,395+0,0113 \mathrm{~W}
$$

in which $\mathrm{VO}_{2}$ is the oxygen uptake $\left(1 . \mathrm{min}^{-1}\right)$ and whe external workload (Watt).

Comparing the individual regression equations with the general regression equation, inter-individual differences were found (figure 5.7). The first constant varied from 0,291 to 0,787 between subjects. No significant correlation was found between the first constant and body weight, neither between the first constant and absolute wmax. The 
slope differed slightly, between individuals varying from 0,0111 to $0,0116$.

Comparing mean measured $\mathrm{VO}_{2}$ max with estimated $\mathrm{V}_{2}$ max by means of the general regression equation, revealed a general tendency of underestimation of $\dot{V} U_{2} \max$ (table $A 1$ ). In some subjects the difference between mean measured and mean estimated $v_{2} \max$ amounted to approximately $10 \%$. No levelling off of oxygen uptake occurred in any of the subjects during the test with gradually increasing workloads although in some subjects the oxygen uptake flattened somewhat at nigh workloads. Only if a subject did not finish a certain workload and consequently the oxygen uptake had to be measured within $1 \frac{1}{2}$ minute, a smaller than expected increase in oxygen uptake was abserved. It was observed occasionally that oxygen uptake increased disproportionally at near maximal workloads.

The variation in $\dot{V}_{2}$ expressed as the standard deviation was smaller at submaximal than at maximal workloads, and varied inter-individually between 0,174 at summaximal and $0,3691$. min $^{-1}$ at maximal work loads.

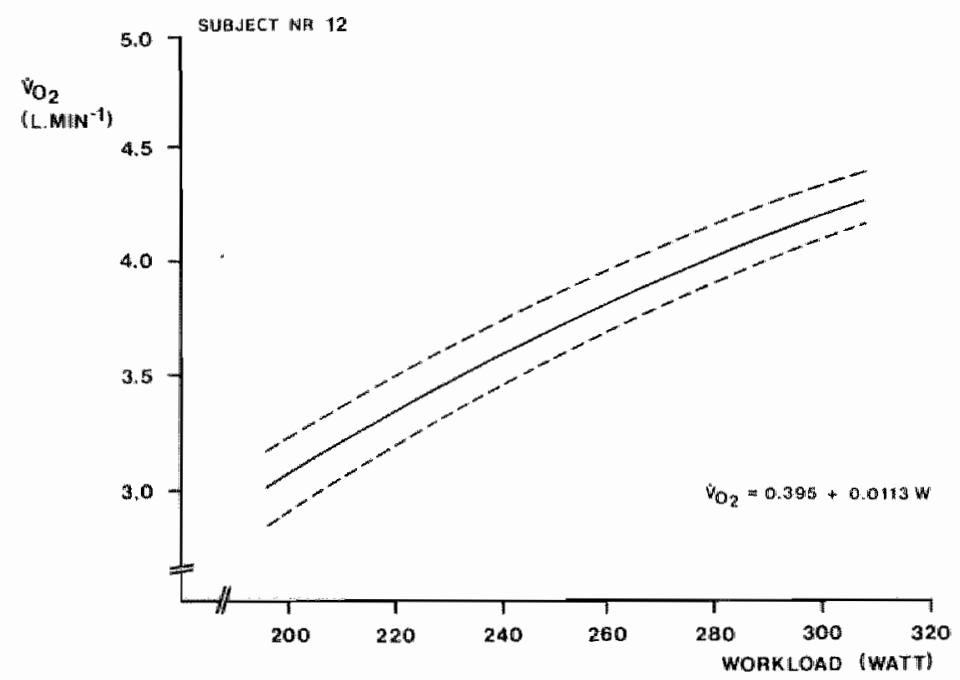

figure 5.?

Mean oxygen uptake and $95 \%$ confidenee limits plotted as function of external workload over all measurements in one subject. $(n=19)$ 
Mean mechanical efficiency as calculated from the oxygen uptake at $70 \%$ Whax varied inter-individually between 19 and $23 \%$ (mean 20,8\%)(table A1). No significant relation $(p>0,10)$ was found between calculated mechanical efficiency and absolute max, or wmax relative to body weight (Watt. $\mathrm{kg}^{-1}$ ). However, in the subject with the highest whax also the nighest mechanical efficiency was found. The intra-individual variation in mechanical efficiency, expressed as standard deviation varied from 0,3 to $1,5 \%$.

\subsection{Comments}

Heart rate showed a nearly linear increase with worklaad, but in some subjects a tendency to levelling off was observed. In some of the female subjects heart rate at $70 \%$ of Wmax was found to be relatively high. Consequently in these subjects heart rate showed a relatively little increase during increasing exercise. A relatively sinall increase in heart rate during increasing workloads does not necessarily mean that cardiac output increases proportionally as an increase in stroke volume may compensate for the small increase in heart rate (Ástrand and Rodahl, 1970). This, in spite of the fact that in general from a heart rate of about 110-120 beats. min $^{-1}$, stroke volume does not increase significantly. Enhancement of cardiac output can then only be obtained by an increase in heart rate (Åstrand and Rodah $7,19 \% 0$ ). The latter investigators, however, reported that some subjects maintained increasing stroke volume until maximal workloads. Also without an increase in cardiac output, oxygen uptake can theoretically be increased by increasing extraction and/or bloodflow to the muscle. From the present study no conciusions can be drawn about the compensatory mechanism, responsible for the increase in oxygen uptake in the absence of a concomitant increase in heart rate.

Generally, maximal neart rate decreases with age (Åstrand and Rodahi, 1970). However no significant correlation between maxinal heart rate and age was found in the present study. It may be argued that the subjects in this study were young and differed in age onlly to 
a limited extend. However, we observed a non-signnificant correlation $(\rho>0,10)$ between age and maximal heart rate in a population varying in age between 20 and 60 years $(r=0,69 ; n=60)$.

Maximal heart rate attained showed a variation in all subjects. This is in agreement with the findings as reported by other investigators (Ästrand and Saltin, 1961). It may be argued that this variability in maximal heart rate is caused by differences in the level of exertion. This, however remains unknown.

Generally $\dot{V}_{E}$ increased somewhat curvilinearly with increasing workloads. This was caused by an increase in both tidal volume and respiratory rate; the latter generally being the most important at high workloads. In some subjects, however, relatively low maxinal respiratory rates were observed. These subjects compensated the relatively small increase in respiratory rate by a relatively pronounced increase in tidal wolume. The physiological significance of this phenomenon remains obscure.

In all subjects the increase in tympanic temperature was related to relative workload, which is in agreement with data presented by other investigators (Ástrand, 1960; Salt in and Hermansen, 1966). The values of the tympanic temperature were relatively low. This may partly be explained by the difficulties encountered in positioning the temperature electrodes, because painful sensations in the ear often interfered with correct placement. Beside this, dislocation of the electrodes might occur during exercise, resulting in a drop in tympanic temperature readings. The duration of the test may also have influenced the recorded tympanic temperatures, because other investigators (Saitin et al, 1968; Davies et a1, 1971) reported that during steady state exercise core temperature only reached stable levels after about 20 minutes. However, the latter authors used rectal temperature, which is considered to have a slower response to changes in core temperature than tympanic tenperature (Nadel, 1977).

No difference in tympanic temperature response to exercise was found between the different periods of the menstrual cycle which contrasts with recent findings of Stephenson and co-workers (1982). These investigators, however, measured rectal temperature during steady state exercise, which may explain the different results. 
In all subjects after an initial rise, back-skin temperature dropped during exercise to values that were lower than the resting values. The initial rise in back-skin temperature at the beginning of the exercise test is assumed to result from increased blood flow to the skin (Saltin and Hermansen, 1966). The successive fall in backskin temperature is considered to be caused by vasoconstriction and evaporation of sweat (Nakayama et al, 1977), which seems to be related to relative workload as indicated from the present study.

Uxygen saturation in venous blood rose to near arterial values during exercise, while in some cases at near maximal loads a drop in oxygen saturation was observed. Although at rest blood drawn from a forearm vein does not represent arterial blood, during exercise the blood flow through the cutaneous veins increases to such an extent that the oxygen saturation rises to near arterial values. The arterialisation of venous blaod during exercise indicates the presence of arterio-venous shunting (Yoshida et al, 1982). The drop in oxygen saturation at maximal workloads may be explained by venoconstriction or diminished arterio-venous shunting.

The decline in $\mathrm{pCO}_{2}$ with increasing exercise intensity probably results from hyperventilation.

Blood lactate concentration showed an exponential increase with increasing workloads. Large differences in maximal lactate concentrations were found between individuals. Also the submaximal blood lactate concentrations varied considerably from subject to subject. These differences may accur because the blood lactate cancentration results from a combination of factors such as the amount of lactate produced, the exchange of lactate between muscle fibers and blood, and the use of lactate as a substrate by muscle fibers and other tissues like heart and liver (Hernansen et al, 1975; Essen et al, 1975; Bonen et a1, 1979; Tesch et a1, 1980).

The relationship between oxygen uptake and external workload was nearly linear up to maximal workloads and could be approximated by a linear regression equation. This means that $\mathrm{V}_{2}$ max can be estimated by determining the maximal workload attained. Although in general the difference between estimated and measured vo $_{2}$ max is less than $6 \%$, in some subjects a difference of about $10 \%$ was found. In some subjects at 
high workloads the increase in oxygen uptake flattened somewhat without showing a real levelling off in any of our subjects. This is in contrast with the findings of other investigators (Niemela et a1, 1980; Holimann and Hettinger, 1980). These investigators, however, loaded the subject on the bicycle ergometer at a revolution rate of 50 rpin, while the optimal revolution rate to elicit $v_{2}$ max on a bicycle ergometer was found to be 70 to $90 \mathrm{rpm}$ (Hagberg et al, 1975). That differences in revalution rate may explain the discrepancy observed, is supported by the observation in our laboratory that cycling at 50 rpm resulted in a 25\% decrease in max and levelling off of oxygen uptake. Whax and $\mathrm{V}_{2}$ max were not significantly different, when the revolution rate varied becween 70 and 90 rpm (unpublished results). It is likely that low revalution rates require more force per revolution, while muscle contraction has to be maintained for a longer period of time during each movement. This may interfere with local blood flow, resulting in increased anaerobic metabolism. These observations might be indications that the phenomenon of levelling off of oxygen uptake may be caused oy limitation at the muscular rather than the cardiorespiratory level. The latter is in agreement with the data of Gleser and co-workers (1974) who found that $\dot{\mathrm{V}}_{2}$ max is higher, the larger the mass of muscle tissue actively involved in the exercise will be.

Mechanical efficiency during submaximal exercise varied between subjects from 19 to $23 \%$ which is in keeping with the values as reported by other investigators (Ástrand and Rodah1, 1970; Hollmann and Hettinger, 1980). Differences may be caused by differences in specific bicycle training, although in all the subjects cycling was a daily activity. However, the subjects, except one, did not cycle at a competitive level. This may explain the high mechanical efficiency in this particular subject. 
6. EVALUATIUN OF PARAMETERS TO ESTIMATE PHYSTCAL EMDURANCE IN THE LABORATORY

\section{1 Hecuvery of heart rate}

After grouping the experiments per subject according to the Wmax attained, the heart rate values at one and five minutes after stopping the exercise were compared. Mean heart rate at one minute after stopping exercise varied between individuals from 166 to 138 beats.min $^{-1}$ (mean 157). Five minutes after stopping the exercise mean heart rate varied between indiwiduals from 141 to 92 beats.min ${ }^{-1}$ (mean 129). The intra-individual variation in heart rate during the recovery period was reflected in the relatively llarge standard deviation, varying from. y to 14 beats min $^{-1}$ between the individuals. In none of the subjects a relationship was found between the recovery of heart rate at different whax values attained and maximal heart rate. Neither a relationship was found between the recovery of heart rate and the absolute level of Wnax or Wnax related to body weight. Only in 1 subject a faster recovery of heart rate as compared to all other subjects was found. This difference was statistically significant. The latter subject nappened to be the one with the highest wax, relative to body weight.

6.2 The indirect method of Astrand-Khyming to predict $\dot{V}_{0}$ max from submaximal neart rate

Per subject the experiments were grouped according to whax attained, while the mean predicted $W_{2}$ max and the mean measured $v 0_{2}$ max were compared. Two subjects had to be excluded for estimating $\mathbf{w}_{2}$ max, because their heart rates after 5 minutes at the first workload did not meet the required range of $120-170$ beats.min $^{-1}$.

The results are listed in table $A 3$. In general the individual difference between mean estimated and mean measured $\dot{V}_{2}$ max was a systematic one, which varied inter-individually between 0 and $19 \%$. The systematic difference resulted in a general overestimation of $\mathrm{VO}_{2} \max$ in some subjects and an underestimation in others. In general $\mathbf{v o}_{2} \max$ was overestimated in the male subjects and sightly underestimated im 
the female subjects.

In most subjects the intra-jndividual variation in predicted and measured $\mathrm{VO}_{2}$ max was similar although variations in measured $\mathrm{V}_{2}$, max and wmax were not always paralleled by changes in predicted $\mathrm{V}_{2}$ max.

We also compared the measured with predicted $v_{2} 2_{\text {max }}$ values as corrected for age and maximal heart rate attained (Åstrand and Rodah], 1970). When using the correction factor based upon maximal heart rate attained, the differences between measured and predicted $\mathrm{VO}_{2}$ inax reduced. Therefore, the data presented in this study were corrected for maximal heart rate attained.

\subsection{Anaerobic threshold}

For each subject the workloads at which the mean wenous blaod lactate concentration amaunted to 4 mol. $1^{-1}$ are presented in table A4. Eight subjects had to be excluded for this part of the study, because lactate values were lacking or the lactate levels exceeded 4 mmol. $1^{-1}$ at the lowest morkload. In general the mean anaerobic threshold was snifted according to the Whax attained. This means that the mean anaerobic threshold was reached at a higher workload when higher wmax values were reached. However, this shift was not observed when the mean anaerobic threshold was plotted as function of rellative Wmax. If Wmax increased, mean anaerobic threshold generally tended to be reached at a lower relative workload (figure 6.1). Im general, the anaerobic threshold was attained at a load of on the average $74 \%$ Wmax, varying from 64 to $90 \%$ between subjects. No relationship was found between the percentage of Whax at which the mean anaerobic threshold was attained and absolute workload. No differences were observed between males and females. Although the mean anaerobic threshold varied with wax, the anderabic threshold determination from single experiments showed considerable variation. Considering the $95 \%$ probability interval of blood lactate concentrations at a given workload, differences in anaerobic threshold varying from \pm 3 to $\pm 7 \%$ could be found, although the same Wmax values were attained. 


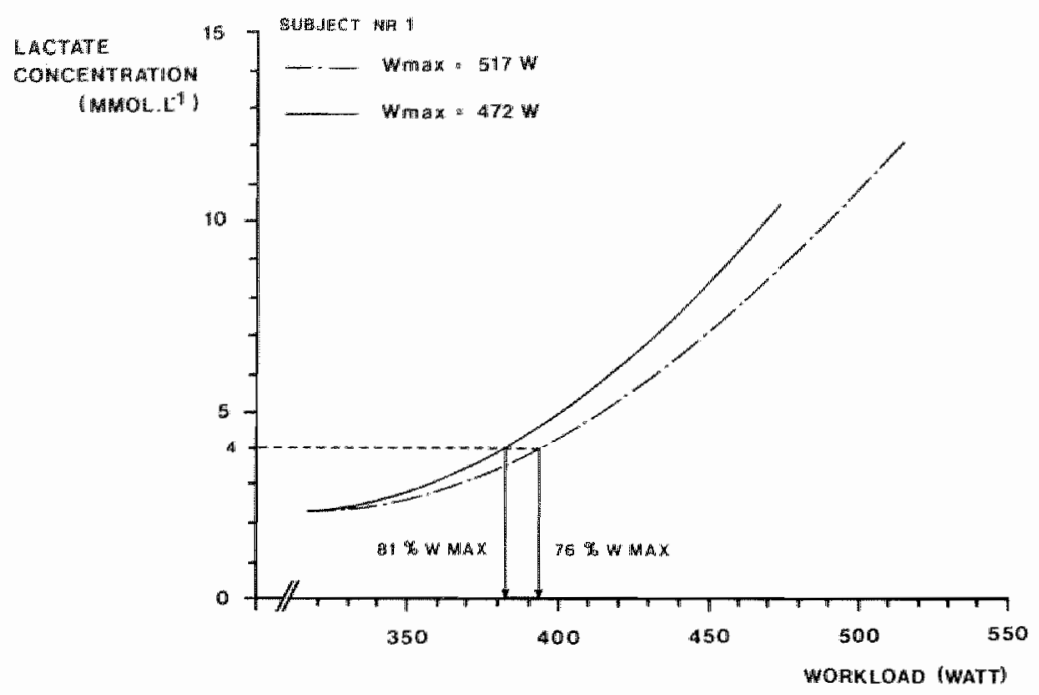

figure 6.1

Mean bload lactate concentration as a function of extemal workload in expemiments with diffement wax. The relative workload at which the lactate concentmation amounted to 4 mol. $2^{-1}$ is indicated.

Table 6.1

The means and standard deviations of endurance time, heart rate and lactate concentration per test are presented

testor.

mean endurance

time

$(\mathrm{min})$

$20 \pm 10$
$51 \pm 17$
$29 \pm 12$
$45 \pm 16$

mean heart rate mean lactate conat the moment of centration at the exhaustion (beats. $\mathrm{min}^{-1}$ ) moment of exhaustion (mmol. $\left.1^{-1}\right)$

\begin{tabular}{ll}
\hline $172 \pm 12$ & $5,64 \pm 3,31$ \\
$168 \pm 12$ & $5,65 \pm 2,04$ \\
$169 \pm 12$ & $5,12 \pm 2,31$ \\
$173 \pm 11$ & $6,51 \pm 3,15$
\end{tabular}




\subsection{Endurance time at a constant workload}

Ten subjects were loaded at $80 \%$ of the individua maximal womkload While endurance time was measured. Per test the mean values of heart rate and biood lactate concentration at the moment of exhastion were calculated. They are listed in table 6.1 .

The mean endurance time in test 1 and 3 was less than that in test 2 and 4. This was not reflected in the mean heart rate and mean lactate level at the moment of exhaustion. In test 1 and 3 the subjects complained more about local fatigue and pain in the thign muscles than in test 2 and 4 . The endurance time of the 3 trained subjects did not differ from that of the untrained subjects in trial 1 and 3 , while in test 2 and 4 the endurance trained subjects tended to sustain the workload for a longer period of time.

The moment of exhaustion was not reflected in the heart rate and lactate levels, neither in the untrained nor in the 3 trained subjects. Considerable differences in endurance tipe were observed intraindividually. Occasionally the endurance times differed more than 100\% between comparable tests in one subject. Intra-individual differences in endurance time especially occurred in test 1 and 3 . No effect of test sequence could be detected (two way variance analysis).

\subsection{Comments}

Among athletes the recovery of heart rate is supposed to be an indicator of physical endurance. This idea was not confirmed by the results in the present study. Only in one subject, who had the highest Hax and competed in endurance activities for years, a fast recovery of heart rate which differed significantly from the other subjects, was seen. However, also in this subject no relation between recovery of heart rate and Wnaw attained was observed. The latter is caused by the considerable intra-individual test to test variability in recovery of neart rate.

Comparison between measured $\dot{V} O_{2}$ max and $\dot{V} O_{2}$ max as estimated from heart rate at submaximal workloads (the Astrand-Rhyining test) showed an inter- as well as intra-individual variation. The systematic over- 
or underestimation of $v_{2}$ max in individuals results from inter-individual differences in response of heart rate. It has been assumed that the changes in heart rate as function of relative workload are similar for all subjects (Astrand and Rhyming, 1970). The results of the present study indicate that this assumption is valid to a limited extend, because inter-individual differences can accur (section 5.1), resulting in systematic errors in the estimation of $10_{2}$ max. In most subjects the heart rate walues used to predict vomax as accurately as possible, net the requirements as set by wyndham (1967), resulting in an intra-individual variation in estimated $\mathrm{V}_{2} \max$ which is comparable to that in measured $\mathrm{V}_{2}$ max. This confirms the assumption that within an individual the variability in estimated and measured $\mathrm{VO}_{2}$ max is similar (Binkhorst, 1982). However, occasionally within an individual differences up to $10 \%$ were found between estimated and measured $\forall u_{2} \max$, on a day to day basis. This is in keeping with the findings reported by Wright and co-workers (1978). This variation is caused by the intra-individual variation of heart rate at a given submaximal workload. These variations are unrelated to changes in maximal heart rate or measured $\dot{v} a_{2} \max$ which is in agreement with the findings reported by Rowell and co-investigators (1964). The origin of these intraindividual differences in heart rate at a given submaximal workload is unknown and occurs in spite of the fact that the tests were performed under standard conditions as far as day of the week, exercise on preceding days, time of the day, room temperature, pedal frequency and procedure are concerned.

Although in the present study the revolution rate was higher than the 50 ar 60 rpm generally used, it is unlikely that this has influenced the accuracy of the prediction of $\mathrm{VO}_{2}$ max. Jessup and co-workers (1977) reported that the accuracy of the Astrand-Rhyming test was mot markedly changed when using a revolution rate of 50 or $80 \mathrm{rpm}$.

By comparing measured and predicted $\hat{V}_{2}$ max, corrected for age or maximal heart rate, it turned out that correction for maximal heart rate is preferable to that for age. This is caused by the inter-individual variation in maximal heart rate, which is independent of age over a wide range (section 5.1).

Changes in whax were generally parallelled by changes in anaerobic 
threshold because with higher haxax levels the blood lactate concentration of 4 mmol. $1^{-1}$ is reached at higher worklloads (section 4.3 ). However, with an increase in Whax value, the relative workload at which the blood lactate concentration amounts to 4 mol. $1^{-1}$ shows a decrease. The latter is caused by a steeper increase in blood lactate concentration when Wmax values are lower; at higher Wmax values a more gradual increase in blood lactate concentration is found. It remains unknown whether these differences in increase in blood lactate concentration are caused by differences in lactate production, wash-out or both.

The findings in the present study show that occasionally intraindividuai variations in anaerobic thresmold up to $10 \%$ may occur between experinents with the same max. However, generally in experiments with the same Wmax value, variations in anaerobic threshold from \pm 3 to $\pm 7 \%$ are found. This variation results from variations in blood lactate concentration at a given workload.

The endurance time, as measured by loading subjects at a constant workload, showed a considerable variability, even in comparable tests and in spite of the fact that each subject was loaded at the same relative workload. The subjects mainly complained of local fatigue and pain in the thigh muscles. The moment of giving up was generally deternimed by this local fatigue as well as by a general feeling of exhaustion. The monent of exhaustion was not reflected in physiological variables as heart rate and venous blood lactate concentration. Because the total exercise time was less than 60 minutes, glycogen depletion was probably not the dominant factor in the perception of local fatigue. Motivational factors may have rather great influence on endurance time, because in this particular study the subjects complained about the soul-killing character of this activity and needed much encouragement to continue the exercise. Therefore, the moment of giving up seems to be influenced by local fatigue and lack of motivation. The decreased endurance time in test 1 and 3 can be explained by the preceding test performed, causing incomplete recovery. Great differences in test to test endurance times were observed intra-individually. Especially in test 1 and 3 the intra-individual differences were marked. The differences in endurance time between subjects as 
found in the present study are in agreement with those described by Geysel (1979). 
7. FATIGUE IN A SUBJECTIVE AND OBJECTIVE PERSPECTIVE

7. Kelationship between perceived signs of fatigue and physical performance

The experiments in each subject were grouped according to the wax attained. The means and standard deviations of the various subjective feelings at the moment of exhaustion are summarized in table $A 5$.

The means of the various stress-factors ranged from 1 to 10 . Comparing experinents with the same wax in one subject revealed that the mean walues of the various stress factors relatively seldom reached the mark 9 or 10 . These mean walues, however, obscure the fact that in single experiments always at least one 9 or 10 was scored. In table A5 heat stress is not listed, because it turned out that heat stress never was severe enough to score higher than 6 . The main stressful factors that caused the subjects to give up were general fatigue, respiratory stress, painful feelings in the working muscles and loss of strength in the muscles which was perceived as if the legs got paralyzed. It appeared that in 10 subjects 9 was the nighest mark scored, while in the other subjects 10 was scored frequently. No ciear relationship could be observed between respiratory stress and any respiratory variable. Neither a clear relationsinip between any of the physiological variables and muscle pain or loss of muscle strength could be observed.

Comparing per subject the means of the various stress factors and the whax attained, it was found that the mean scores of respiratary stress and general fatigue increased at higher wmax values. This tendency was observed in all subjects. The sensation of pain in the working muscles showed the opposite, i.e. the higher the whax attained is, the lower the mean score of muscullar pain will be. No such clear tendency was found between whax attained and loss of muscle strength.

Although the mean values of some stress factors tended to be related to wax attained, the factor that caused a subject to stop a single exercise test could be different of arigin. In some tests the matin reason for stopping was general fatigue, while on other days respiratory stress or muscular pain was the main reason for stopping, 
despite the fact that the same wmax values were attained.

Prediction of whax from subjective feelings of fitness before the test, differed considerably from the whax attained. Actual Wmax was underscored or overscored by 5 to $10 \%$. The frequencies of $5 \%$ underscore, exact scare and $5 \%$ overscore were equal. A $10 \%$ underscore or a $10 \%$ overscore occurred less frequently. No clear inter-individual differences in the accuracy of predicting wax were found.

The estimation of whax after the first 5 minutes of exercise was more accurate in all subjects. In about $80 \%$ of the experiments winax was predicted accurately, while in $10 \%$ Wmax was underscored or overscored. The underscore and averscore were maximally $5 \%$.

\subsection{Comments}

Heat stress never scored higher than 6 , indicating that the heat dissipation was not really stressful. This may be explained by the ventilator that was placed in front of the subject and could be used on demand.

It was found that in 9 subjects a 10 was scored frequently. It appeared that the subjects who never scored a 10, had been active in competitive endurance sports and ever experienced more severe stress than during the laboratory tests. This indicates that during competition the level of motivation, that counterbalances the physical stress, is higher, thus producing a more severe level of exhaustion. It might be expected that respiratory stress is reflected in changes in the respiratory variables, but this was not the case in the present study. Although mean respiratory rate and mean respiratory stress tended to be increased at higher Wmax, comparison of the respiratory variables and respiratory stress revealed that in single experiments no significant correlation could be found. Similar observations were made on general fatigue and pain in the working muscles. This is in agreement with the findings of Pandolf and co-workers (1972) who reported that general fatigue is not related to heart rate or ventilatory variables. So it seems that changes in respiratory rate or minute volume, do not necessarily cause the feeling of respiratory stress. 
While working at low intensity, the subjects could estimate their maximal performance rather accurately. It may be argued that the subjects could manipulate Wmax, because thearetically they were able to know the workloads given. Although during the test no information was given to the subjects about workloads or the values of variables, they could deduce the workloads since the protocol was similar each test and measurements were done at regular intervals. However, before the start of the test, the prediction of wax was inaccurate which may be an argument against manipulation of wax by the subject. The difference in accuracy of estinating whax from subjective feelings indicates that in the resting state perception of physical sensations is no reliable indicator for actual working capacity. During exercise, however, the actual working capacity can be estimated rather accurately from the perception of physical sensations. However, during the first experinents that were used as a try out and were discarded for final analysis a much less accurate estimation was found. The subjects probably need a reference which can be obtained by experience. This is in accordance with observations in atmletes that during exercise the maximal performance level can be estimated rather well from physical signs. 


\section{GENERAL DISCUSSION}

In summary the findings in the present study demonstrate that maximal workload attained ( $m a x$ ) and $\dot{V}_{2} \max$ vary substantially when assessed on a week to meek basis. These variations were random and no seasonal influences or influences of the menstrual cycle could be detected. The variation in wax is likely to be biological in origin because an increase and a decrease in whax is associated with a shift of a number of physiological variables to the right and the left, respectively when they are plotted as a function of external workload. This shift disappeared if the same variables were plotted as a function of relative workload, which implicates that within a subject a given relative workload is associated with values of the warious physiological variables within narrow llimits. However, even in experiments in which the same tmax was attained, inter- and intra-individual differences in physiological responses to exercise were found. The latter finding may explain the limited validity of tests in which physical endurance or $\dot{V}_{2}$ max is predicted from blood lactate concentrations or heart rate values, attained at submaximal workloads. Because of the linear relationship between external workload and oxygen uptake, $\forall 0_{2}$ max can be estimated by determining Wmax since no levelling off of oxygen uptake at maximal workloads was observed.

The variability in wax is considered to be biological in origin since differences in Whax were associated with a shift of the physiological variables, when plotted as a function of external workload (figures 4.2 and 4.3). However, psychological factors will certainly influence the results obtained. The finding that each subject reached a number of distinct wax values, was probably also affected by psychological factors because the subjects were assumed to be intrinsically or extrinsically motivated to finish a certain workload, once started. On the other hand if a subject felt to be able to sustain a higher workload only for a few seconds, he will probably not start the next higher workload in the scheme. It is assumed that the influence of psychological factors on Winax is rather limited. The motivational influence on the duration to sustain a heavy workload is also present 
in athletic activities, since it can be abserved frequently that the motivational drive to maintain a certain speed can be kept by the athlete until the finish is reached, after which he may collapse completely. The variability in whax as found in the present study was different from subject to subject. It is supposed that the variability in physical performance is an individual feature. The variability as found in the present study is slightly higher than that of physical perfomance in athletes. By calculating in individual athletes the coefficient of variation in mean speed or the time needed to cover distances in athletic events, which last between 2 and 15 minutes, values between 1 and $5 \%$ can be obtained (umpublished results). Therefore, it is postulated that the variability in physical performance in athletes is also mainly determined by biological factors, while psychological factors may influence performance only to a limited extent.

No influence of the menstrual cycle on wmax was abserved. This is in contrast with the findings as reported by other investigators (Pahlke and Smitka, 1977; Hollmann and Hettinger, 1980), who reported diminished physical endurance just prior to and during the menstrual phase. Because Pahlke and Smitka (1977) showed that the menstrual phase may influence physical performance, especially in women with dysinenorrhea, part of the discrepancy may be explained by the fact that in the present study none of the female subjects suffered from dysmenorrhea. Another factor that may have masked the influence of the menstrual cycle on physical performance is the way in which the menstrual cycle was classified. Differences may occur between the classification of the menstrual cycle into 4 phases of equal duration as used in the present study and the classification, based upon hormone levels (Jurkowski et al, 1978). Moreover, it should be realised that the quoted authors investigated female top athletes, while the subjects in our study were active at the recreational level.

Changes in whax were reflected in a shift of the physiological variables, when they were plotted as a function of external workload. This shift, however, disappeared if the physiological variables were plotted as a function of relative workload. The latter indicates that the magnitude of the physiological responses to exercise is related to relative workload. This means that within a subject a given rela- 
tive workload is always associated with values of the various physiological variables within narow limits.

Although the shift in physiological variables, assaciated with changes in wax (figures 4.2 and 4.3 ), suggests that the energy cost of exercise may differ on a week to week basis, significant changes in axygen uptake at a given workload could only be found in 3 sulbjects. However, though not statistically significant, also in the other subjects changes in oxygen uptake, related to whax, were obserwed. Differences in energy cost at a given worklaad may result from a variety of factors. It may be hypothesized that changes in coordination of movements or changes in metabolic efficiency in skeletal muscle may occur. In both cases the energy required for a given workload will change, depending on the degree of coordination andior the metabolic efficiency. To meet the power, required at a given workload, reduced coordination and/or a decrease in metabolic efficiency will lead to increased stimulation of motor units. This results in increased oxygen uptake, stimulation of the cardiorespiratory system and increased lactate production. The recruitment of extra motor-neurons might explain the subjective feeling that on "bad" days the subjects had to concentrate on cycling in order to keep the pedals going which costed much effort. On "good" days, however, cycling seemed to go automatically without any effort. From the results in the present study no conclusion can be drawn about the validity of the hypothesis concerning coordination and/or metabolic efficiency. A finding that is difficult to explain with this hypothesis is that the maximal value of some of the physiological variables tended to be increased when higher wax values were reached. The following possibilities might be thought of for the various variables. Since the duration of the test increases when Whax attained increases, higher core temperatures will be reached, because more time is available to transport heat through the body (Davies et all, 1971). Ewen a small rise in core temperature may lead to extra stimulation of the cardiorespiratory system (Schmidt and Thews, 1980). The increased maximal blood lactate concentration at nigher max values might be explained by the longer period of time that is available for the wash out of lactate from the working muscles and/or an increased production of lactate. 
The physiological responses to exercise varied intra- as well as inter-individually. Within a subject the same wax value could be associated with pronounced differences in maximal values of the physiological variables. This indicates that the ciranges in regulation of the cardiorespiratory system are not necessarily completely reflected in the changes in physical perfomance. This may be explained by compensatory mechanisms of the body as shown by Epstein and coworkers (1965). These reported that changes in oxygen transport to the muscle as caused by decreased cardiac output after beta-adrenergic blockade, can be compensated for by increased axygen extraction. This is supported by recent investigations, which showed that after application of beta-receptor blocking agents a decrease in maximal heart rate of about 20-30\% may be associated with a decrease in $\mathrm{Vu}_{2}$ max and wax of only 5-10\% (see for references van Baak, 1983).

Comparison between subjects revealed that each subject has his awn characteristics concerning physiological responses to exercise. In some subjects, for example, ventilation increased mainly by a rise in respiratory rate and in others mainily by a rise in tidal volume. Barrying this in mind it can be understood that not all subjects could fulfill all the criteria used to estimate whether a subject was maximally exerted. Therefore, the use of one criterion to decide whether a subject is really exerted, is insufficient.

In the present study no levelling off of oxygen uptake was found at maximal workloads. This finding is not in keeping with the observations of other investigators (Astrand and Rodah1, 1970; Hollimann and Hettinger, 1980). As discussed in section 5.9 the occurrence of levelling off of oxygen uptake may be caused by the protocol as well as by the revolution rate used. In the present study it was occastionally observed that oxygen uptake increased disproportionally at near maximal and maximal workloads. This finding confirms the observations of Niemela and co-workers (1980). The results of the present study indicate that this phenomenon is associated with a disproportional increase in $\dot{V}_{E}$ at near maximal workloads. Therefore, it may be speculated that the disproportional increase in oxygen uptake is caused by increased activity of the muscle tissue, involved in respiration. To further evaluate the levelling off phenomenon we performed a pilot 
study in which the subjects were loaded at supramaximal workloads. It was found that wa $2^{m a x}$ was increased proportional to the rise in workload above whax only if the workload could be sustained for at least 2 siniriute.

Because the relationship between external workload and oxygen uptake can be approximated by a linear regression equation, $\mathbf{V}_{2}$ max can be estinated by determining whax. However, a systematic under- or overestimations up to about 10 may occur in some individuals. In bicycle trained people $\mathrm{V}_{2}$ max may be overestimated and in people who are not bicycle trained 10 , max may be underestimated because of differences in efficiency. Estimation of $V_{2}$ max from wax values may be of practical importance, because no expensive equipment is necessary. Besides, this estimation seems somewhat more accurate than estinating $\mathrm{V}_{2}$ max from heart rate at a given submaximal workload, at least when using the protocol of the present study. However, estimating $\dot{v}_{2}$ max from wnax with the protocol used in the present study takes about 20 minutes and maximal exertion, whereas estimating $10_{2}$ max from heart rate at a given submaximal workload takes only 6 minutes.

The accuracy of other indirect methods to estimate Vu$_{2}$ max or physical endurance from submaximal heart rate or blood lactate cancentration are linited too because of the inter-and intra-individual variation in these variables. From the results of the present study it can be concluded that inter-individual comparison of $\dot{v} \mathrm{O}_{2}$ max as predicted from heart rate attained at a given submaximal workload, can easily lead to erroneous conclusions. Even within one subject, changes in predicted $\dot{V}_{2}$ max do not necessarily reflect changes in physical endurance. However, since the variations in predicted and measured $\mathrm{V}_{2}$ max are similar, the same can be concluded for changes in measured $\operatorname{vo}_{2}^{2} \max$.

Although in general an increase in wnax was associated with an increase in the workload at which the blood lactate concentration amounted to 4 mol. $1^{-1}$, test to test variations varying from \pm 3 to $\pm 7 \%$ were found. The latter implicates that a difference in anaerobic threshold between 2 tests may not necessarily be interpreted as a change in physical endurance. Since the bload lactate concentration, and consequently the anaerobic threshold, cam be influenced by a 
variety of factors, it may be questioned whether this concentration is a reliable indicator for the transition from aerobic to anaerobic metabolism. Turner and his collegues (1981) showed that changes in prestart glycogen may influence the lactate formation and consequentily the anaerobic threshold. Another factor that may influence blood lactate concentration is the exchange of lactate between muscle and plood. Tesch (1982) demonstrated that the gradient for lactate concentration between muscle and blood can differ inter-as well as intraindividualiy by more than 20\%, while the correlation coefficient between inuscle and blood lactate concentration was found to be 0,89 . Although the half life-time of lactate exchange between muscle and blood has been considered to be about 30 seconds for years (Margaria et al, 1964; Whipp and Wassermann, 1972), recent research showed that the exchange is greatly dependent on the blood flow during exercise (Graham et al, 1976). Sahl in and co-workers (1976) studied the muscle and bload lactate concentration after exercise and observed a half life-time of lactate exchange between muscle and blood of 9,5 minutes. In the latter study, however, the subjects rested completely after exercise, so the exchange of lactate from muscle to blood may have been influenced by the absence of dynamic inuscle function. The quoted studies suggest that wash-out of lactate may be influenced by the revolution rate used. The latter is supported by the findings of Turner (1981) who observed a shift in the anaerobic threshold with different revolution rates at the same external load, using a bicycle ergometer. In this study at higher revolution rates the load at which the blood lactate amounted to 4 molo $1.1^{-1}$ was shifted to a lower workload. This may be explained by an enhanced lactate wasn-out at higher revolution rates. However, differences in recruitment of motor units at different revolution rates also have to be taken into account. Although in the present study the revalution rates were kept constant, the relative workload at which blood lactate concentration amounted to $4 \mathrm{~mol} \cdot \mathrm{l}^{-1}$, tended to be shifted to relatively lower workloads when the subjects attained a higher Whax (figure 6.1). This was caused by variations in the increase of lactate concentration. In the experiments in which a low whax was reached, the rise in blood lactate concentration was steeper as compared to the experiments in which a 
higher whax was attained. It may be speculated that these differences are caused by differences in recruitment of motor units. On "good" days type I fibers could be recruited preferably, while type II fibers might be recruited additionally only at higher workloads. On "bad" days, however, type If fibers might have been recruited at lower workloads, resulting in an increased lactate production. The latter might explain the increased blood lactate levels at all workloads as well as the steeper rise in blood lactate concentration at lower whax values.

Considering the estimation of physical endurance or changes in physical endurance in athletes, it is likely to be important that the test method used should have great similarity to the actual athletic activity. In sports which especially appeal to aerobic endurance of the thigh muscles, the maximal workload attained on a bicycle ergometer may be a more sensitive parameter for changes in physical endurance than measured or estimated $\hat{V}_{2}$ max and anaerobic threshold. This assumption is supported by observations in cyclists, made by Snoeckx and co-warkers (1983). These investigators tested cyclists 4 times a year during the resting season, the preparation season, the competitive season and the slowing down season. It turned out that absolute $\dot{v} o_{2} \max$ and $\dot{v}_{2} \max$ relative to body weight were not significantly different in any of the seasons, while whax was lower in the resting than in the preparation and competitive season. Because no differences in maximal values of heart rate, blood lactate concentration and $\dot{V}_{E}$ were found, it may be assumed that the level of exertion has been similar during all tests. Therefore, it is indicated that wimax relative to body weight may be a mare sensitive parameter for estimating physical endurance in athletes than measured and estimated $\dot{v}_{2}$ max or anaerobic threshold. The latter is supported by similar findings in British cyclists (white et al, 1982). However, one should realize that atnletic performance depends on such factors as technical ability, aerobic and anaerobic physical endurance and mental stability. Each laboratory test includes only some aspects of athletic performance, while factors as anaerobic power, tecnnique and motivation are difficult to measure in the laboratory setting. Even if a cyclist is tested on a bicycle ergometer, we can only judge about one important pre- 
requisite for a good cyclist, i.e. Vu 2 max or wax. We have no information about his tactical insight, sprinting capacity, anaerobic capacity and his ability to sustain high workloads during several hours. These factors are just as important as $\mathrm{vO}_{2}$ max and whax. Coaches and other people invalved in attending athletes should realize that the most specific and most sensitive test is the competition itself. 


\section{SUMARYY AMD CONCLUSIONS}

The aim of the present study was to evaluate the variability of physical performance and of phystological responses to a standardized exercise test with gradually increasing workloads. The influence of the menstrual cycle on physical performance was included in the study. Besides, the relationship between oxygen uptake and external warkload was investigated. The validity of some laboratory tests, generally used to estimate physical endurance and the relationship between physiological variables and subjective perception of fatigue were studied as well.

Mineteen subjects, 11 males and 8 females, who were physically active at the recreational level, participated in the study. Weekly, they performed a standard exercise test with increasing workloads. Each subject performed the test at least 14 times. Each volunteer had an individual protocol based upon the mean of the maximal workloads attained in 2-3 preliminary tests (mean test-wmax). Each test started at $70 \%$ of the mean test-Wmax. Inis load was maintained for 5 minutes, whereupon each 2 minute the workload was increased by a load which was $5 \%$ of the mean test-wmax. In each test the load was increased until exhaustion. At rest, during the last 30 seconds of each workload and 1 and 5 minutes after exercise the following variables were determined: heart rate, expiratory volume $\left(\ddot{W}_{E}\right)$, respiratory rate, axygen uptake $\left(\forall U_{2}\right)$, respiratory exchange ratio $(R)$, respiratory equivalent $\left(\hat{V}_{E} / \mathrm{VO}_{2}\right)$, lactate concentration, $\mathrm{pH}, \mathrm{pCO}_{2}$ and $\mathrm{O}_{2}$ saturation in venous blood, and back-skin and tympanic temperature. Besides, maximal workload attained (Whax) and mechanical efficiency were assessed. Before the test started, the subjects were asked to estimate the Wnax walue which they thought to achieve. This question was repeated after the first 5 minutes of exercise. At the end of the test the subjects had to score on a 10-point scale the subjective feelings at the moment of exhaustion, such as general fatigue, respiratory stress, heat stress, pain or loss of strength in the muscles (chapter 2).

The accuracy of the methods to measure the physiological variables was estimated by comparing calibration values with the registrated values, and/or by comparing the resuits of duplicate or repeated 
measurements (chapter 3).

wnax and $\mathrm{VU}_{2} \max$ waried in all subjects in a random way (chapter 4). The coefficient of variation in whax varied inter-individually from 2,95 to $6,83 \%$ (mean $4,79 \%$ ), and that of $\dot{V}_{2} \max$ from 4,20 to $11,35 \%$ (mean $7,58 \%$ ). Discrepancies between whax and $\mathbf{v 0}_{2}$ max were observed frequentiy. No seasonal influences or influences of the menstrual cycle on $\dot{V}_{2}$ max and whax could be established. By grouping the experiments in each subject according to the Whax attained and by plotting the physiological variables as a function of external workload, a shift in these variables, related to the Wmax attained, was found. This means a shift to the left at lower whax values an to the right at higher whax values. If per subject the variables were plotted as a function of relative workload, the snift disappeared, indicating that the inagnitude of physiological responses to exercise is related to relative rather than absolute workload. This finding implicates that within a subject a given relative workload is associated with values of the various physiological variables within narrow limits.

Considerable inter-individual differences in physiological responses to exercise were found (chapter 5). Within one subject the physiological responses may vary up to $10 \%$, even in experiments in which the same wmax is attained. The relationship between oxygen uptake and external workload could be characterized by a linear regression equation. Because no levelling off of oxygen uptake was found at higher workloads, $\mathrm{VO}_{2} \max$ can be estimated from this equation by determining Wmax. In same subjects, systematic over- or underestimation of $\dot{V}_{2}$ max may amount to approximately $10 \%$.

In chapter 6 some parameters, which are used to estimate physical endurance, were evaluated. Recovery of heart rate is no reliable parameter for physical endurance. In some subjects systematic differences up to $19 \%$ were found between $\dot{v}_{0} 2^{\max }$ as estimated from heart rate at a given submaximal workload and the measured $\dot{V}_{2}$ max. Within one subject, in experiments in which the same Hmax was attained, the variation of heart rate at a given workload leads to an intra-individual variation in predicted $\mathrm{V}_{2} \max$ of some percents. Therefore within a subject $\mathrm{V}_{2}$ max may be over- or underestimated systematically, while the reproducibility of estimated and measured $\dot{V}_{2} \max$ are similar. Changes in 
anaerobic threshold, being the workload at which the blood lactate concentration amounts to $4 \mathrm{mmol}^{-1} \mathrm{l}^{-1}$, were generally associated with changes in wax. However, from a change in the workload at which the blood lactate concentration amounts to 4 mmol. $7^{-1}$, max cannot be predicted accurately because of the intra-individual variation in blood lactate concentration at a given workload which varied between subjects from \pm 3 to $\pm 7 \%$. In a separate study the endurance time at a constant workload, $80 \%$ of the individual wax as measured in a previous test, was investigated. In comparable tests a difference in endurance time up to $100 \%$ was found between as well as within individuals. The moment of exhaustion was not reflected in the values of the physiological variables such as heart rate or blood lactate concentration.

The relationship between perceived physical signs of fatigue and physiological variables were investigated in chapter 7. Before exercise started the subjects could not predict Whax accurately. However, after the first 5 minutes of exercise, Wnax could be estimated rather accurately from physical signs. Respiratory stress and general fatigue tended to be increased at nigher max values, while pain in the muscles was more often reported at lower whax values. A relatively large variation in stress factors at the moment of exhaustion was observed, inter- as well as intra-individually. No clear relationship could be found between stress factors and physiological variables. This supports the view that the phenomenon of fatigue is rather complex and remains incompletely understood.

In conclusion:

- Wmax and 10 , max vary on a week to week basis, which is independent of the season, the phase of the menstrual cycle or the level of physical performance.

- the variation in $\mathrm{VO}_{2}$ max is more pronounced than that in wax, while discrepancies may occur between changes in $\mathrm{VO}_{2} \max$ and thax.

- Wmax is probably a more sensitive parameter for changes in physical 
endurance than $\dot{V}_{2}$ max.

- within a subject the magnitude of the physiological responses to exercise is related to relative rather than absolute workload.

- physiological responses to a standardized test may vary up to $10 \%$ inter- as well as intra-individually.

- $\dot{V} U_{2}$ max can be estimated from heart rate at a submaxinal workioad or from wax, because oxygen uptake and external workload are linearly related without levelling off of oxygen uptake at higher workloads. Generally, estimating $\mathbb{v}_{2}$ max from Wmax is more accurate than from submaximal heart rate.

- changes in wmax are generally associated with changes in anaerobic threshold. In experiments with the same Wmax value, the variation in anaerobic threshold varies between individuals from \pm 3 to $\pm 7 \%$.

- no significant relationship was found between perceived signs of fatigue at the moment of exhaustion and physiological variables. 


\section{SAMENVATTING EN CONCLUSIES}

Spierarbeid vraagt energie. Hoe meer energie de spier ter beschikking krijgt, hoe meer arbeid geleverd kan worden. De energie, nodig voor net samentrekken van spleren worat geleverd door splitsing van een in de spler aanwezige energierijke fosfatverbinding, net ATP. Het ATP is te beschouwen als een universele energleleverancier voor alle cellulaire processen die energie kosten. Naast voortdurende splitsing van ATP, ook in rust, vindt continue nieuwvorming (resynthese) plaats. Dit kan op verschillende manieren gebeuren. Als de cel genoeg zuurstaf ter beschikking heeft, wordt pyrodruivenzuur, dat via chemische afsplitsing uit glucose ontstaat, in de mitochondrien (de "energiecentrales" van de cell volledig verbrand tot kooldioxide en water. Omdat dit proces zuurstof vraagt wordt dit wel aerobe stofwisseling genoemd. Dit aerobe proces gaat relatief langzaam en levert maximaal 2,2 mmol ATP per kilogram droog spiergewicht per seconde. Als de ATP afbraak de aerobe resynthese capaciteit overtreft, zoals bij zware arbeid, kan extra ATP gemaakt worden door anaerobe afbraak (zonder zuurstof) van glucose. De ontstane hoeveelheid pyrodruivezuur die niet meer volledig in de mitochondrien kan worden verbrand, wordt in melkzuur (lactaat) omgezet (anaerobe glycolyse). Dit proces is sneller dan de aerobe verbranding en levert per seconde ongeveer 2 keer zoveel ATP. Het lactaat verzuurt echter het cellulaire milieu waardoor o.a. de anaerobe glycalyse zelf geremd wordt. Vooral bij maximale inspanningen tot \pm 60 seconden speelt anaerabe glycolyse een zeer beliangrijke rol voor het snel leveren van ATP. Als het lichaam vanuit rust zich maximaal moet gaan inspannen wordt het ATP zeer snel verbruikt. Undat de glycolyse enige tijd nodig heeft on op gang te komen, vindt gedurende de eerste seconden snelle resynthese van ATP plaats door splitsing van een ander in de cel aanwezig energierijk fosfaat, het creatinefosfaat (CP). Door deze snelle reactie wordt ongeveer $12 \mathrm{mmol}$ ATP per $\mathrm{kg}$ droog gewicht per seconde gewonnen. Helaas is de CP woorraad slechts voldoende om enkele seconden maximale inspanning mogelijk te naken.

Sportprestaties kunnen op grond van de energieleverantie als volgt worden onderverdeeld:

a. Inspanningen die tot 1 minuut duren, zijn vooral afhankelijk wan 
anaerobe energiewinning. We spreken wel van anaeroob withoudingsvermogen.

b. Inspanningen tussen 1 en 10 minuten zijn vooral afhankelijk van energiewinning die aeroob maximaal geleverd kan worden. hier is het aerobe uithoudingsvermogen een zeer belangrijke faktor voor de sportprestatie.

c. Bij inspanningen die langer duren zoals marathon e.d. is het van belang dat de atleet kan werken op een hoog percentage van zijn maxinale aerobe energieleverantie. Hier is ook het aerobe uithoudingsvermogen erg belangrijk.

Ondat begeleiders van sporters graag geinformeerd willen worden over de effecten van training heeft men getracht inethodes te vinden om het uithoudingsvermogen te schatten. Een belangrijke voorwaarde voor een goed uithoudingsvermogen is de energieleverantie. Terwijl het meten van anaerobe energiewinning moeilijk is, kan aerobe energiewinning relatief gemakkelijk gemeten worden. Het is bekend hoeveel energie het lichaam met behulp van een liter zuurstof kan vrijmaken. Hoe hoger het vermogen om zuurstof op te nemen is, hoe meer energie geleverd kan worden, en hoe hoger het aerobe uithoudingsvermogen zal zijn. Daaron wordt de maximale zuurstofopname $\left(\dot{v}_{2} \max \right)$ als belangrijke parameter (maat) voor het uithoudingsvermogen van duursporters gebruikt. Het meten van de $\dot{\mathrm{V}}_{2}$ nax vraagt echter een goed geoutilleerd laboratorium, zodat gezocht is naar methodes on de $\dot{V}_{2}$ max te schatten bijvoorbeeld uit de hartfrequentie die bij een submaximale belasting bereikt wordt (de Åstrand-Rhyming test). Een andere methode on het uithoudingsvermogen te schatten is het bepalen van de belasting waarbij het lactaat in het bloed $4 \mathrm{mmol} . \mathrm{l}^{-1}$ is, omdat verondersteld wordt dat deze concentratie de grens aangeeft warbij de stofwisseling van aeroob naar anaeroob overgaat. In de praktijk worden verschillen in test resultaat vaak vertaald in veranderingen van het uithoudingsvermogen. Het is echter niet bekend of variaties in deze geschatte waarden ook betekenen dat het uithoudingsvermogen inderdaad veranderd is ondat niet precies bekend is hoe reproduceerbaar $20^{\prime} n$ laboratoriumtest is. Naast deze vraag zijn er in de sportpraktijk nog andere niet opgeloste problemen die van belang zijn voor het begeleiden van sporters. Zo is 
het bekend dat het prestatievermogen van sporters zonder danwijsbare oorzadk kan varieren. Verder bestaan er tegenstrijdige opvattingen over de invloed van de menstruele cyclus op het prestatievermogen bij de vrouw. Deze onduidelijkheden hebben geleid tat de huidige studie warbij getracht werd een antwoord te geven op de valgende vragen:

- wat is de variabliteit yan het fysieke prestatievermogen en de fysiologische reakties, tijdens het uitvoeren van een gestandaardiseerde fietsergometerproef.

- welke invloed heeft de menstruele cyclus op het prestatievermogen.

- wat is de relatie tussen witwendige belasting en zuurstofopmame.

- wat is de validiteit (warde) van de laboratorium testen die algemeen gebrukt worden on het prestatievermogen te schatten.

- welke relatie is er tussen subjectieve gevoelens van vernoeidheid en fysiologische variabelen.

om deze vragen te kumnen beantwoorden, werden 11 mannelijke en 8 vrouwelijke proefpersonen wekelijks aan een fietsergometertest onderworpen. De proefpersonen waren lichamelijik aktief op recreatief niveau. In hoofdstuk 2 worden de in deze studie gebruikte methodes beschreven. Iedere proefpersoon had zijn eigen belastingsprotocol. un dit protocol vast te kumnen stellen, werd elke proefpersoon 2-3x getest, waarbij steeds het maximaal gehaalde vermogen werd bepaald (test-Wmax). Het gemiddelde van deze 2-3 waardes, het gemiddelde maximale vermogen, werd als uitgangspunt woor het protocol genomen. vit protocol bestond wit het gedurende 5 minuten fietsen op $70 \%$ var het gemidclelde maxhale vermogen, warma elke 2 z minut de belasting werd opgevoerd met een stapgrootte die $5 \%$ van het gemiddelde maximale vermogen bedroeg. De belasting werd opgevoerd tot uitputting. In rust, gedurende de laatste 30 seconden van elke belastingsstap en 1 en 5 minuten na afloop van de test werden de walgende fysiologische variabelen gemeten: hartfrequentie, ademinuutwolume $\left(\dot{V}_{E}\right)$, adenfrequentie, zuurstofopmame $\left(\dot{V} O_{2}\right)$, respiratoir quotient $(R)$, adenequivalent $\left(V_{E} / \mathrm{VO}_{2}\right)$, lactaatconcentratie, $\mathrm{pH}, \mathrm{pCO}_{2}$, en $0_{2}$ saturatie (=verzadiging) in het veneuze bloed en de huid-en trammelvi iestemperatuuur. De hoogste belastingsstap die werd bereikt (Wmax) en de mechanische 
efficientie werden eveneens bepaald. Verder moesten de proefpersonen voor aanvang van de test en na de eerste 5 minuten belasting voorspellen wat ze die dag voor maximale belasting zouden halen. Na afloop werd gevraagd hoe ze zich voelden op het moment van uitputting voor wat betreft ademstress, pijn in de spieren of krachtsverlies en algemene vernoeidheid.

In hoofdstuk 3 wordt beschreven hoe nauwkeurig de methodes zijn on de verschillende fysiologische variabelen te meten. Dit werd nagegaan door vergelijking van meetresultaten met ijkwaarden en/of aan de hand van duplo of meerdere metingen.

In hoofdstuk 4 wordt beschreven dat de whax en $\dot{v}_{2}$ inax wardes varieren zonder dat hierin een speciaal patroon kan worden waargemonen. Tussen individuen varieerde de variatie-coefficient voor whax van 2,95 tot $6,83 \%$ (gemiddeld $4,79 \%$ ) en voor $\mathbf{v 0}_{2} \max$ van 4,20 tot $11,35 \%$ (gemiddeld 7,58\%). Er werden frequent discrepanties tussen whax en $\mathrm{V}_{2}$ max gevonden. Geen invloed van jaargetijde en menstruele cyclus op Whax en $v_{2} 2^{\text {max }}$ kon worden aangetwond. Door experimenten binnen elke proefpersoon te groeperen naar de bereikte whax waarde, bleek er, afhankelijk van de hoogte van de max, een verschuiving op te treden in de fysiologische variabelen als deze werden uitgezet als functie van de belasting. Dit wil zeggen een verschuiving naar links bij lage Whax waardes en een verschuiving naar rechts bij hoge whax waardes. De verschuiving verdween als de fysiologische variabelen werden uitgezet als functie van de relatieve belasting. Dit betekent dat voor elke proefpersoon bij een bepalde relatieve belasting min of meer vaste waardes van de verschillende fysiologische variabelen horen.

In hoofdstuk 5 wordt beschreven dat er inter- en intra-individuele verschillen in fysiologische reactie tijdens inspanning kunnen bestaan tot $20^{\prime} n$ 10\%. Zelfs als eenzelfde Whax waarde bereikt wordt, kan er binnen een persoan een variatie in de fysiologische variabelen bij een zelfde belasting te zien zijn, van soms $10 \%$. De relatie tussen zuurstofopname en belasting kan worden benaderd door een lineaire regressie-vergelijking ondat er geen afvlakking van de zuurstofopname (levelling off) bij hoge belastingen werd gezien. De $\dot{V}_{2}$ max kan uit deze vergelijking geschat worden door de Whax te bepalen. Voor sommige proefpersonen kan een systematische over- of onderschatting van de 
Vu. $2^{\text {niax }}$ tot ongeveer $10 \%$ worden gevonden.

In hoofdstuk 6 worden enkele methodes geevalueerd, die in de praktijk gebruikt worden, am of het uithoudingsvermogen, of veranderingen daarin, te schatten. Het herstel van de nartfrequentie bleek geen relatie te hebben met de Wmax en lijkt derhalve geen goede maat te zijn voor schatting van het uithoudingsvermogen. De $\mathbf{v O}_{2}$ max waardes, geschat uit de hartfrequentie bij een bepaalde submaximale belasting (de Astrand test), bleken bij proefpersonen systematisch te kunnen verschillen van de gemeten $\dot{V}_{2}$ max waardes. Het verschil tussen voorspelde en gemeten $\mathbf{W O}_{2}$ max wardes was bij enkele proefpersonen $19 \%$. binnen een proefpersoon bleken bij experimenten met eenzelfde whax variaties in hartfrequentie te leiden tot een spreiding in de geschatte $\mathbf{v}_{2}$ max van enkele procenten. Deze spreiding is vergelijkbaar met die van de direkte $v_{2} u_{2}$ ax metingen. Daarom kan gesteld worden dat de $\dot{\mathrm{V}}_{2}$ max systematisch over - of onderschat kan worden, terwijl de reproduceerbaarheid van voorspelde en gemeten $\dot{V}_{2} \max$ vergelijkbaar is. De belasting waarbij de bloedlactaat concentratie 4 mol per liter bedroeg (anaerobe drempe1), verschoof in het algemeen naar een hogere waarde als de imax een hogere walarde bereikte. Er werden incidenteel variaties in de melkzuurconcentratie bij een gegeven belasting gevonden van meer dan 10\%, ondanks een zelfde wmax. In het algemeen echter schomelde de variatie in anaerobe drempel tussen de proefpersonen bij eenzelfde Wmax waarde tussen \pm 3 tot $\pm 7 \%$. Een daling of steiging van de belasting waarbij de lactaatconcentratie 4 mal per liter bedraagt, hoeft derhalve niet te betekenen dat het uithoudingsvermogen daadwerkelijk is veranderd. De volhoudtijd bij een belasting van $80 \%$ van de van te voren bepaalde wmax, bleek sterk te kunnen varieren, onafhankelijk wan veranderingen in wax. Uitputting kwam niet tot uitdrukking in de fysiologische variabelen als hartfrekwentie en lactaatconcentratie in het bloed.

De relatie tussen subjectieve gevoelens van vermoeidheid en fysiologische variabelen wordt beschreven in hoofdstuk 7 . Het bleek dat proefpersonen in rust moeilijk hun prestatie konden voorspellen, terwijl dit wel goed mogelijk was na de eerste 5 minuten belasting. Ademstress en algemene vermoeidheid neigden hoger te scoren bij toename wan de whax. Pijn in de spieren daarentegen kwamen vaker voor bij 
lagere whax waardes. Tussen de verschillende personen bestond een relatief grote variatie in scores van de verschillende stressfactoren, zoals die ervaren werden op het moment wan uitputting. ook binnen individuen bestond een aanzienlijke variatie in subjectieve gevoelens op het moment van uitputting. Er was geen duidelijk verband aantoonbaar tussen verschillende subjectleve gevoelens van stress en fysiologische variabelen. Dit steunt de opvatting dat het verschijsel vermoeidheid zeer complex is en mar zeer ten dele wordt begrepen.

Samenvattend kan gesteld worden dat:

- Wmax en $\dot{V}_{2}$ max van week tot week varieren, terwijl er geen verband bestaat met de menstruele cyclus, het jaargetijde en het prestatievermogen.

- de variatie in $\mathbf{V}_{2}$ max groter is dan die in whax, terwijl er discrepanties tussen veranderingen in $\mathrm{V}_{2}$ max en wmax kunnen voorkomen.

- Wmax waarschijnlijk een gevoeliger mat voor veranderingen in uithoudingsvermogen is dan $\mathrm{V}_{2}$ max.

- bij elke proefpersoon de grootte van de fysiologische reacties op inspanning gerelateerd is aan de relatieve en niet aan de absolute belasting. Dit betekent dat binnen een persoon bij een gegeven relatieve belasting wardes voor de verschillende fysiologische variabelen gevonden worden, die binnen nauwe grenzen liggen.

- de fysiologische reacties op inspanning niet alleen tot zo'n $10 \%$ kunnen varieren tussen personen, doch ook binnen een individu.

- $\mathrm{V}_{2}$ max geschat kan worden uit de hartfrequentie biji een submaximale belasting en uit de wmax omdat er een lineair verband bestaat tussen zuurstofopname en uitwendige belasting, terwijl er geen afvlakking van de zuurstofopname bij hoge belasting optreedt. Het schatten van de $\dot{v} 0_{2} \max$ uit de whax is in het algemeen wat nauwkeuriger dan het schatten van de $\dot{V}_{2}$ max uit de hartfrekwentie bij 
een submaximale belasting.

- veranderingen in Whax in het algemeen samen gingen met veranderingen in de anarobe drempel. In experimenten warbij dezelfde wax warde gehada werd, schomelde de variatie in de anaerobe drempel tussen de proefpersonen wan $\pm 3- \pm 7 \%$.

- er tijdens uitputting geen duidelijk verband gevonden wordt tussen subjectieve gevoelens van vermoeidheid en fysiologische variabelen. 


\section{REFERENCES}

Astrand, P.u.

Experimental studies of physical working capacity in relation to sex and age.

Munksgaard, Copenhagen, 1952

Ástrand, P.0., 1. Rhyming

A nomogram for calculation of aerobic capacity from pulse rate during submaximal wiork.

J.Appl.Physiol. 7, 218-222, 1954

Astrand, P.O.

Aerobic workcapacity of men and women, with special reference to age. Acta Physiol. Scand. 49 suppl. 169, 1960

Astrand, P.o., B. Saltin

Oxygen uptake during the first minutes of heavy muscular exercise

J. App 1. Physiol. 16: $971-975,1961$

Astrand, P.U., K. Rodahl

Textbook of work physiology

Whirew, Hill book Co, New York St.Louis, San Francisco, London, 1970.

Baak, M. van, W. Jennen, F. Verstappen

Heart rate reduction and maximal work capacity during acute and chronic beta receptor blockade

Abstract for ACSM meeting 1983 accepted. To be published in Med. Sci Sports Exercise 1983

Bergmeyer, H.U.

Methods of enzymatic analysis vol. 3

Academic press Inc., New York 1974, pp. 1465-1491

Binkhorst, K.A.

De Astrand fietstest

Gen. en Sport 6: 198-199, 1982

Binkhorst, R.A., R. v. Leeuwen

A rapid method for the determination of aerobic capacity.

Int. Z. angew. Physiol. einschl. Arbeitsphysiol. 19: 459-467, 1963

Binkhorst, R.A., A.C.A. Vissers, W. Geerts

Submaximale inspanningsproeven met verschillende fietsergometers

Gen.sport $\mathrm{nr} .3,50-52,1973$

Bonen, A., C.J. Campbell, R.L. Kirkley, A.N. Belcastro

A multiple regression model for blood lactate removal in man

Pflügers Arcn. 380: 205-210, 1979

Borg, G.

Physical performance and perceived exertion

(i) eerups, Lund, 1962 
Borg, $G$.

Percelved exertion; a note on history and methods

Med. Sci. Sparts 5: 90-93, 1973

Costill, D.L., W. J. Fink, M. U. Palliack

Muscle fiber composition and enzyme activities of elite distance rumners.

Med.Sci Sports 2, 96-100, 1976

Croonen, F., R.A. Binkhorst

Oxygen uptake calculated from expiratory volume and oxygen analysis only

Ergonomics $17,113-117,1974$

Daniels, J.T., R.A. Varbrough, C. Forster

Changes in 10 max and running performance with training

Eur. J. Appl. Physiol. 39: 249-254, 1978

Davis, J.A., P. Vodak, J.H. Wilmore, J. Vadak, P. Kurtz

Anaerobic threshold and maximal aerobic power for three modes or exercise

d.Appl. Physiol 41: $544-550,1976$

Uavies, C.T.M.

Limitations to the prediction of maximal oxygen intake from cardiac frequency measurements.

J. Appl. Physiol. 24: 700-706, 1968

Davies, C.T.M., L. Barmes, A.J. Sargeant

Body temperature in exercise

Int. Z. angew. physiol. 30: 10-19, 1971

Diem, K., C. Lentner

Wissenschaftliche Tabellen

Ciba Geigy AG, Basel 1971

Dixon, W.d., M.B. Brown, editors, BMDP-79

University of California Press, Berkeley, Los Angelos, London 1979

Ekblom, B., A.M. Goldberg

The influence of physical training and other factors on the subjective rating of perceiwed exertion

Acta Physial. Scand. 83, 399-406, 1971

Enschede, $F *$ A.J.

Over de training van schatsenrijoders

Thesis, University of Utrecht, 1960

Epstein, S.E., B.F. Robinson, R.L. Kahler, E. Braunwald

Effects of beta-adrenergic biockade on the cardiac response to maximal and submaximal exercise in man

d. of Clin. Inv. 44: 1745-1753, 1965 
Essen, B., B. Pernow, P.D. Gollnick, B. Saltin

Muscle glycogen content and lactate uptake in exercising muscles in: metabolic adaptations to prollonged physical exercise. Eds.: H. Howald, J.R. Poortmans Birkhauser Verlag, Basel, 1975 pp. 130-134

Fearn, T.

A Bayesian approach to growth curves

Bionetrika 62: 89-100, 1975

Fleisch, A.

Weue Methoden zur untersuchung des lasaustauches und der Lungenfunktion

Thierne, Leipzig. 1956

Geyse 1, 4.S.M.

Onderzoek naar de relatie tussen trainingsarbeid en veranderingen in de trainingstoestand van marathon schaatsers in het seizoen $1973 / 1974$ Gen.Sport 2: 6-17, 1976

Geyse1, J.S.M.

Training and testing in marathon speed skating

J. Sports Med. 19: 277-284, 1979

Glassford, R.t., G.H.Y. Baycraft, A.W. Sedgwick, R.B.J. MacNab

Comparison of maximal oxygen uptake values determined by predicted and actual methods

J. App1. Physiol. 20: 509-514 1965

Gleser, M.A., J.A. Vogel

Endurance capacity for prolonged exercises on the bicycle ergometer U. Appl. Physiol. 34(4): 438-442, 1973

Gieser, M.A., D.H. Horstman, R.P. Mell lo

The effect of $10_{2}$ max of adding arm work to maximal leg work

Med. Sci. Sports ${ }^{2} 6:$ 104-107, 1974

Graham, T., G. Sjögaard, H. Löllgren, B. Saltin

iv. A.D. in muscle of man at rest and during exercise

Pflügers Arch. 376: 35-39, 1978

Hagberg, J.M., M.D. Glese, J.P. Mull in

Effect of different gear ratio on the metabolic responses of competitive cyclists to constant load during steady state work

Med. and Science in Sports 7: 74-78, 1975

Hagberg, J.M.K, M.D. Giese, R.B. Schneider

Comparison of three procedures for measuring $\dot{V} 0_{2}$ max in competitive cyclists

Eur.J.Appl.Physio1. 39, 47-52, 1978

Hermansen, L., B. Saltin

Oxygen uptake during maximal treadmi11 and bicycle exercise

J. Appl. Physial. 26: 31-36, 1969 
Hemansen, L., S. Maehlun, E.D.R. Pruett, 0. Vaage, H. Waldum, T. Wessel-Aas

Lactate renoval at rest and during exercise. In: Metabolic adaptations to prolanged physical exercise. Eds. H. Howald, J.R. Poortmans, Birkhauser Verlag Basel, 1975 pp 101-105

Hollmann, W.

Zur Frage der Dauerleistungsfähigkeit

Forsch. Med. 79: 439-443, 1961

Hollmann, W., Th. Hettinger

Sportmedizin - Arbeits und Trainingsgrundlagen

F.K. Schattauer Verlag, Stuttgart-New York 1980

Houston, M.E., H. Bentzen, H. Larsen

Interrelationships between skeletal inuscle adaptations and performance as studied by detraining and retraining

Acta physiol. Scand. 105: 163-170, 1979

Ingen Schenau, G.J. van,

A power balance applied to speed skating; thesis

Free University Amsterdam 1981

Jessup, G.T., C.E. Riggs, J. Lambert, W.D. Milier

The effect of pedalling speed in the validity of the Astrand-Ryhming aerobic workcapacity test

J. Sports Med. 17: 367-371, 1977

Jurkowski, J.E., N.L. Jones, W.C. Walker, E.V. Younglai, J.R. Sutton Ovarian hormonal responses to exercise

J. Appl. Physiot. REEP $44(1): 109-114,1978$

Jurkowski, J.E., N.L. Jones, C.J. Toews, J.R. Sutton

Effects of menstrual cycle on blood lactate, $0_{2}$ delivery and performance during exercise.

Can. J. Appl. Phystol. REEP 51: 1493-1499, 1981

Katch, V.L., S.S. Sady, P. Freedson

Biological variabitity in maximum aerobic power

Med. Sci. in sports and exercise 14: 21-25, 1982

Keren, G., A. Mayazanik, Y. Epstein

A comparison of various methods for the deternination of $\mathrm{VO}_{2} \max$

Eur.J.App1.Physiol. 45, 117-124, 1980

knowlton, R.G., M.N. Sawka, D.T. Deutsch

Varied intensity treadmill protocols for measurement of maximal oxygen uptake

J.Sportsmed. 17, 263-268, 1977

Kuipers, H., F.T.J. Verstappen, R.S. Reneman

Influence of therapeutic doses of amoxicillin on aerobic work capacity and some strength characteristics

Am.J.Sportsmed. 8, 274-279, 1980 
Lindley, D.V., Srittin, A.F.M.

Bayes estimates for the linear model

J.R. Statist. Soc. B, 34: 1-41, 1972

Mader, A., H. Liesen, H. Heck, H. Philippi, R. Rost, P. Schürch, W. Holl linann

Zur Beurteilung der sportartspezifischen Ausdauerleistungsfähigkeit im Labor

Sportartzt und Sportmed. 4: 80-88, 1976 and 5: 109-112, 1976

Mathews, D.K., E.L. Fox

The physiological basis of physical education and athletics

Saunders co., Philadel phia, London, Toronto, 1976

Mc.Lellan, T., T. Feroan, J.S. Skinner

The effect of work load duration on the determination of the aerobic and anaerobic thresholds

Med.Sci Sports exercise 13: 69, 1981

Margaria, R., P. Cerretelli, F. Mangili

Balance and kinetics of anaerobic energy release during strenuous exercise in man

J.App 1. Phys 101. 19: 623-628, 1964

Moncrieff, $J$.

Individual differences, reliabilities and inter-correlations of oxygen intake measurements

J. Spartsmed. $8,153-157,1968$

Myles, W.S., K.J. Toft

A cycle ergometer test of maximal aerobic power

Eur. J. App T. Physiol. 49: 121-129, 1982

Nade1, E.R.

Problems with temperature regulation during exercise

Academic press inc. London, 1977

Nakayama, T., Y. Onnuki, K. Niwa

Fall in skin temperature during exercise

Jap. J. Physiol. 27: 423-437, 1977

Nielsen, B.

Thermoregulation in rest and exercise

Acta Physiol. Scand. Supp1. 323, 1969

Nielsen, M.

Die Respirationsarbeit bei Körperruhe und bei Muskelarbeit

Skand. Arch. Physiol. 74: 299, 1936

Niemela, K., I. Palatsi, M. Linnaluoto, J. Takkunïn

Criteria for maximum oxygen uptake in progressive bicycle test

Eur. J. Appl. Physiol. 44: 51-55, 1980

Otis, A.B. 
The work of breathing

In: W.O. Fenn and H. Rahn (eds): "Handbook of physiology" "Respiration vol. 1, p. 463. American physiological society, Washington DC, 1964

Pahlke, U., H.P. Smitka

Menstruationszyklus und sportliche Leistungsfähigkeit trainierter Sportlerinnen.

Med. und Sport 17: 123-126, 1977

Pandolf, K.B., E. Cafarelli, B.J. Noble, K.F. Metz

Perceptual responses during prolonged work

Percept. Mot. Skills 35: 975-985, 1972

Patton, J.F., J.A. Vogel, R.P. Mello

Evaluation of a maximal predictive cycle ergometer test of aerobic power

Eur. J. Appl. Physiol. 49: 131-140, 1982

Poulus, A.J., F.W.J. Vos

Trapfrequentie en fysiologische belasting

Gen. en sport 1: 12-16; 1982

Prinzen, F.H., M.J.M. Koppelmans, M.J.E. Bernink, W.R. de Vries

Een vergelijking van maximale prestatie en cardiorespiratoire adaptatie gedurende vier verschillende fietsergometertesten

Gen. sport $\mathrm{nr}$. 5, 118-125, 1979

Reekum, J.R., van

Conditie, training en belasting: een onderzoek bij Delftse roeiers

Express Printing, Arnsterdam 1974

Rowel1, L.B., H.L. Taylor, Y. Wang

Limitations to prediction of maximal axygen intake

J. App1. Physiol. 19(5): 919-927, 1964

Rupp, J.C.

Anaerobic threshold measures: variance between method and sex

Med. Sci. Sports and exercise 13: 69, 1981

Sahl in, K., R.C. Harris, B. Nylind, E. Hultman

Lactate content and $\mathrm{pH}$ in muscle samples obtained after dynamic exercise

Pfluegers Arch. 367: 143-149, 1976

Saltin, B., L. Hermansen

Esophagal, rectal and muscle temperature during exercise

J. appl. physiol. 21: 1757, 1966

Saltin, B., A.P. Gagge, J.A.J. Stolwijk

Muscle temperature during submaximal exercise in man

J. Appl. Physial. 25: 679-688, 1968 
Schmidt, R.F., G. Thews

Pnysiologie des Menschen, p. 533

Springer Verlag, Berlin, Heidelberg, Mew York, 1980

Simonson, E., P.C. Weiser

Psychological aspects and physiological correlates of work and fatigue

Charles C. Thomas publisher Springfield, Illinois, USA 1976

snoeckx, L.H.E.H., H.F.M. Abeling, J.A.C. Lambregts, J.J.F. Schmitz, F.T.J. Verstappen, R.S. Reneman

cardiac dimensions in athletes in relation to variation in their training program

Eur. J. Appl. Physiol. to be published in 1983

Scephenson, L.A., M.A. Kolka, J.E. Wilkerson

Percelved exertion and anaerobic threshold during the menstrual cycle. Med. Sci. Sports and exercise 14: 218-222, 1982

Stephenson, L.A., M.A. Kolka, J.E. Wilkerson

Metabolic and thermoregulatory response to exercise during the human menstrual cycle.

Med. Sci. Sports and Exercise 14:270-277, 1982

Strume, S.B., F. Imgjer, H.D. Meen

Assessment of maximal aerobic power in specifically trained athletes J.App 1.Phys101. REEP 42(6), 833-837, 1977

Taylor, H.L., E. Buskirk, A. Herischel

Maximal oxygen intake as an abjective measure of cardiorespiratory performance

J. App 1. Physiol. 8: 73-76, 1955

Tesch, P.A.

Muscle fatigue in man with special reference to lactate accumulation during short tem intense exercise

Acta Physiol. Scand. Suppl. 480,1980

Tesch, P.A., W.L. Daniels, D.S. Sharp

Lactate accumulation in muscle and blood during submaximal exercise Acta Physiol. Scand. 114: $441-446,1982$

Thoss, P., S. Israel

Der Vergleich von gemessener un nomografisch ermittelter maximaler Sauerstoffaufnamme bef Sportlern unterschiedlichen Leistungsvermögens

Med. und Sport 9: 261-266, 1975

Tukey, J.h.

Exploratory data analysis

Addison, Wesley publishing co. Massachussetts, 1977

Tumner, S.C, E.H. Hughes, G.A. Brooks

Effects of glycogen depletion and pedalling speed on the socalled

"Anaerobic threshold".

Med. Scl. Sports and exercise, 13: 69, 1981 
Verstappen, F.T.J., R.M. Huppertz, L.H.E.H. Snoecks

Effect of training specificity on maximal treadmill and bicycle ergometer exercise.

Int. J. Sportsmed. 3: 43-46, 1982

Vos, J.A., R.A. Binkhorst, W. Geurts

Principes van de fietsergometer en de praktische toepassing bij controle van de trainingstoestand

ve Tijastroom, Lochem, 1981

Vries, H.A. de, C.E. Klafs

Prediction of maxinal oxygen uptake from subinaximal tests

J. Sports Med. 5: 207-214, 1965

Wassermann, K.

Detecting the threshold of anaerabic metabolism

An. J. Cardiol. 14: 844-853, 1964

Whipp, B.J., K. Wassermann

Oxygen uptake kimetics for various intensities of constant load work J. App1. Physiol. 33: 351-356, 1972

Whipp, B.J., S.N. Koyal, K. Wassermann

Anaerobic threshold and $\mathrm{O}_{2}$ uptake kinetics for work increment of various durations

Med. Sci. Sports 6: 67-68, 1974

White, J.A., G. Quinn, M. Al-Dawalibi, J. Mullha1l

Seasonal changes in cyclists' performance

Brit. J. Sports, Med. 16: 4-12, 1982

Wilmore, J.H

Physiological responses of women to exercise

In: Exercise and sport sciences reviews, pp 126-150

Academic press inc. London, 1973

Wright, G.R., K. Sidney, R.d. Shephard

Variance of direct and indirect measurements of aerobic power

J. Sports Med. 18: 33-42, 1978

Wyndham, C.H.

Submaximal tests for estimating maximum oxygen intake

Can. Med. Assoc. J. 96: 736-742 1967

Yoshida, T., N. Takeuchi, Y. Suda

Arterial versus venous blood lactate increase in the forearm during incremental bicycle exercise.

Eur. J. appl. physiol. 50: 87-93, 1982 
. 
TABLE AI

Mean whax, mean measured and estimated 10 max and mean mechanical efficiency at 70\% Wimax with coefficients of variation

\begin{tabular}{|c|c|c|c|c|c|c|}
\hline $\begin{array}{l}\text { subj. } \\
\mathrm{nr} \text {. }\end{array}$ & $\begin{array}{l}\text { mean } \\
\text { Wlmax } \\
\text { (Watt) }\end{array}$ & $\begin{array}{l}\text { coefficient } \\
\text { of variation } \\
\text { of Wmax } \\
(x)\end{array}$ & $\begin{array}{l}\text { mean } \mathrm{VO}_{2} \\
\text { max } \\
\left(1 . \text { mi n }^{-1}\right)\end{array}$ & $\begin{array}{l}\text { coeffi- } \\
\text { cient of } \\
\text { variation } \\
\text { of } \mathrm{yo}_{2} \text { max } \\
\qquad \mathrm{y}^{2}\end{array}$ & $\begin{array}{l}\text { mean es- } \\
\text { timated } \\
\text { vo.max } \\
\text { from wnax } \\
\left(1 . \text { min }^{-1}\right)\end{array}$ & $\begin{array}{l}\text { mean me- } \\
\text { chanical } \\
\text { efficiency } \\
(g)\end{array}$ \\
\hline \multicolumn{7}{|l|}{ MALES } \\
\hline $\begin{array}{l}1 \\
2 \\
7 \\
8 \\
9 \\
10 \\
12 \\
13 \\
14 \\
16 \\
17\end{array}$ & $\begin{array}{l}480,5 \\
309,5 \\
228,5 \\
249,2 \\
273,0 \\
270,0 \\
288,2 \\
237,3 \\
231,8 \\
325,6 \\
332,8\end{array}$ & $\begin{array}{l}4,03 \\
4,02 \\
2,95 \\
5,35 \\
6,19 \\
5,29 \\
4,89 \\
5,54 \\
6,83 \\
4,79 \\
4,27\end{array}$ & $\begin{array}{l}5,69 \\
4,03 \\
2,99 \\
3,18 \\
3,66 \\
3,83 \\
4,13 \\
2,84 \\
3,07 \\
4,29 \\
4,12\end{array}$ & $\begin{array}{r}4,20 \\
6,95 \\
10,26 \\
11,35 \\
7,59 \\
6,87 \\
6,19 \\
11,30 \\
6,03 \\
8,20 \\
5,80\end{array}$ & $\begin{array}{l}5,82 \\
3,89 \\
2,97 \\
3,21 \\
3,47 \\
3,44 \\
3,65 \\
3,07 \\
3,01 \\
4,07 \\
4,15\end{array}$ & $\begin{array}{l}23,0 \\
21,9 \\
21,6 \\
22,0 \\
21,2 \\
20,2 \\
19,8 \\
22,9 \\
21,0 \\
21,2 \\
22,8\end{array}$ \\
\hline \multicolumn{7}{|c|}{ FEMALES } \\
\hline $\begin{array}{l}3 \\
4 \\
5 \\
6 \\
11 \\
15 \\
18 \\
19\end{array}$ & $\begin{array}{l}201,4 \\
175,2 \\
198,9 \\
148,8 \\
195,6 \\
174,3 \\
234,7 \\
199,6\end{array}$ & $\begin{array}{l}3,23 \\
5,16 \\
3,40 \\
4,38 \\
5,73 \\
5,83 \\
3,92 \\
5,21\end{array}$ & $\begin{array}{l}2,53 \\
2,33 \\
2,63 \\
2,22 \\
2,78 \\
2,41 \\
3,17 \\
2,58\end{array}$ & $\begin{array}{l}7,69 \\
8,87 \\
6,58 \\
9,98 \\
6,03 \\
8,42 \\
6,89 \\
5,01\end{array}$ & $\begin{array}{l}2,67 \\
2,37 \\
2,64 \\
2,07 \\
2,60 \\
2,36 \\
3,04 \\
2,65\end{array}$ & $\begin{array}{l}22,4 \\
21,0 \\
21,2 \\
19,0 \\
20,1 \\
20,1 \\
21,0 \\
22,1\end{array}$ \\
\hline
\end{tabular}


TABLE AZ MALES

Mean values \pm sd of the various variables at the monent of exhaustion. The experiments are grouped according to the wax attained. In each subject the succesive levels of Wmax are indicated by $A-E$ ( $A$ being the lowest wax).

\begin{tabular}{|c|c|c|c|c|c|}
\hline $\begin{array}{l}\text { sibjo. } \\
\text { nr. }\end{array}$ & $\begin{array}{l}\text { Whax } \\
\text { (Watt) }\end{array}$ & $\begin{array}{l}\text { heart rate } \\
\text { (beats } \text { min }^{-1} \text { ) }\end{array}$ & $(E(5 \pi p q)$ & $\begin{array}{l}\text { Respiratory } \\
\text { rate } \\
\left(\min ^{-1}\right)\end{array}$ & $\begin{array}{l}102^{\max } \\
\left(1 \min ^{-1}\right)\end{array}$ \\
\hline 1 & $\begin{array}{l}450 \mathrm{~A} \\
472 \mathrm{~B} \\
495 \mathrm{C} \\
517 \mathrm{D}\end{array}$ & $\begin{array}{l}177,1 \pm 5,5 \\
178,9 \pm 4,9 \\
180,4 \pm 4,2 \\
178,0 \pm 6,2\end{array}$ & $\begin{array}{l}141,9 \pm 04,2 \\
142,6 \pm 06,9 \\
142,9 \pm 07,3 \\
144,8 \pm 05,1\end{array}$ & $\begin{array}{l}51,9 \pm 2,2 \\
52,8 \pm 2,8 \\
52,5 \pm 1,9 \\
54,7 \pm 1,8\end{array}$ & $\begin{array}{r}\text { abc5, } 37 \pm 0,21 \\
5,80 \pm 0,17 \\
5,78 \pm 0,15 \\
5,50 \pm 0,07\end{array}$ \\
\hline 2 & $\begin{array}{ll}28 b & A \\
300 & B \\
315 & C \\
330 & 0\end{array}$ & $\begin{array}{l}179,5 \pm 4,3 \\
180,4 \pm 3,3 \\
180,0 \pm 2,4 \\
181,9 \pm 2,9\end{array}$ & $\begin{array}{l}86,5 \pm 09,2 \\
89,6 \pm 07,4 \\
91,9 \pm 07,9 \\
99,6 \pm 06,7\end{array}$ & $\begin{array}{l}34,0 \pm 3,6 \\
34,2 \pm 2,6 \\
34,0 \pm 2,2 \\
36,0 \pm 2,8\end{array}$ & $\begin{array}{r}33,78 \pm 0,30 \\
3,96 \pm 0,29 \\
4,08 \pm 0,23 \\
4,20 \pm 0,28\end{array}$ \\
\hline 7 & $\begin{array}{ll}216 & A \\
228 & B \\
240 & C\end{array}$ & $\begin{array}{l}192,3 \pm 4,1 \\
189,5 \pm 2,9 \\
192,5 \pm 3,4\end{array}$ & $\begin{array}{l}82,5 \pm 05,8 \\
78,7 \pm 08,7 \\
78,2 \pm 05,6\end{array}$ & $\begin{array}{l}44,6 \pm 1,1 \\
46,5 \pm 2,5 \\
46,5 \pm 2,6\end{array}$ & $\begin{array}{l}2,74 \pm 0,36 \\
3,08 \pm 0,25 \\
2,89 \pm 0,35\end{array}$ \\
\hline 8 & $\begin{array}{ll}238 & A \\
250 & B \\
263 & C\end{array}$ & $\begin{array}{l}184,2 \pm 8,4 \\
181,3 \pm 5,4 \\
184,0 \pm 2,6\end{array}$ & $\begin{array}{l}83,9 \pm 12,2 \\
89,6 \pm 09,5 \\
99,6 \pm 11,8\end{array}$ & $\begin{array}{l}46,0 \pm 2,9 \\
47,2 \pm 2,1 \\
49,4 \pm 2,2\end{array}$ & $\begin{array}{r}\mathrm{ab} 2,93 \pm 0,21 \\
3,43 \pm 0,37 \\
3,32 \pm 0,28\end{array}$ \\
\hline 9 & $\begin{array}{ll}252 & A \\
266 & B \\
280 & C \\
294 & 0 \\
308 & E\end{array}$ & $\begin{array}{l}185,0 \pm 1,4 \\
182,7 \pm 6,7 \\
185,8 \pm 6,0 \\
183,0 \pm 3,9 \\
182\end{array}$ & $\begin{array}{l}99,1 \pm 07,2 \\
110,5 \pm 14,9 \\
108,1 \pm 07,9 \\
112,7 \pm 09,2 \\
118,5\end{array}$ & $\begin{array}{l}47,0 \pm 1,4 \\
51,1 \pm 4,9 \\
51,1 \pm 3,3 \\
50,7 \pm 2,9 \\
46\end{array}$ & $\begin{array}{l}3,40 \pm 0,24 \\
3,64 \pm 0,30 \\
3,79 \pm 0,26 \\
3,65 \pm 0,17 \\
3,89\end{array}$ \\
\hline 10 & $\begin{array}{ll}255 & B \\
270 & B \\
285 & C \\
300 & D\end{array}$ & $\begin{array}{l}d 175,5 \pm 3,9 \\
175,3 \pm 2,6 \\
178,7 \pm 1,5 \\
181,5 \pm 2,1\end{array}$ & $\begin{array}{r}99,2 \pm 04,8 \\
103,1 \pm 09,5 \\
108,8 \pm 03,3 \\
109,5 \pm 11,8\end{array}$ & $\begin{array}{l}45,4 \pm 1,9 \\
45,5 \pm 2,8 \\
45,5 \pm 3,3 \\
49,5 \pm 6,3\end{array}$ & $\begin{array}{r}c 3,76 \pm 0,17 \\
3,76 \pm 0,26 \\
4,00 \pm 0,20 \\
4,43 \pm 0,10\end{array}$ \\
\hline 12 & $\begin{array}{l}266 \text { A } \\
280 \text { B } \\
294 \text { C } \\
308 \text { D }\end{array}$ & $\begin{array}{l}185,7 \pm 2,9 \\
188,8 \pm 2,3 \\
189,8 \pm 2,2 \\
189,7 \pm 3,3\end{array}$ & $\begin{array}{l}111,3 \pm 09,4 \\
116,7 \pm 09,1 \\
123,0 \pm 06,5 \\
122,6 \pm 08,4\end{array}$ & $\begin{array}{r}247,2 \pm 4,2 \\
54,0 \pm 2,6 \\
53,2 \pm 2,6 \\
52,5 \pm 2,5\end{array}$ & $\begin{array}{r}\text { ec } 3,82 \pm 0,23 \\
3,94 \pm 0,14 \\
4,16 \pm 0,23 \\
4,36 \pm 0,17\end{array}$ \\
\hline 13 & $\begin{array}{l}225 A \\
238 B \\
250 \mathrm{C} \\
2630\end{array}$ & $\begin{array}{l}178,2 \pm 5,0 \\
177,9 \pm 5,6 \\
180,0 \pm 4,8 \\
182,5 \pm 3,5\end{array}$ & $\begin{array}{l}74,0 \pm 08,5 \\
72,4 \pm 07,5 \\
80,3 \pm 03,3 \\
79,8 \pm 03,2\end{array}$ & $\begin{array}{l}38,2 \pm 1,7 \\
38,6 \pm 1,8 \\
39,4 \pm 1,1 \\
41,5 \pm 4,2\end{array}$ & $\begin{array}{l}2,74 \pm 0,28 \\
2,85 \pm 0,36 \\
2,94 \pm 0,36 \\
2,80 \pm 0,17\end{array}$ \\
\hline 14 & $\begin{array}{ll}209 & A \\
220 & B \\
231 & D \\
242 & D \\
253 & E \\
264 & F\end{array}$ & $\begin{array}{l}181,8 \pm 4,2 \\
182,3 \pm 3,2 \\
186,1 \pm 1,5 \\
184,8 \pm 3,8 \\
184,6 \pm 2,3 \\
189\end{array}$ & $\begin{array}{r}103,9 \pm 09,4 \\
98,4 \pm 05,8 \\
105,3 \pm 06,4 \\
105,4 \pm 06,6 \\
110,1 \pm 03,1 \\
108,4\end{array}$ & $\begin{array}{l}59,4 \pm 5,5 \\
57,0 \pm 2,0 \\
58,8 \pm 7,4 \\
60,0 \pm 5,0 \\
63,0 \pm 3,6 \\
55\end{array}$ & $\begin{array}{l}3,07 \pm 0,12 \\
3,08 \pm 0,09 \\
3,07 \pm 0,20 \\
3,07 \pm 0,21 \\
3,25 \pm 0,32 \\
3,35\end{array}$ \\
\hline 16 & 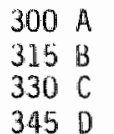 & $\begin{array}{r}c 181,3 \pm 0,5 \\
181,8 \pm 4,7 \\
180,8 \pm 5,4 \\
177,1 \pm 3,5\end{array}$ & $\begin{array}{l}102,9 \pm 13,1 \\
121,0 \pm 04,5 \\
120,9 \pm 17,0 \\
119,2 \pm 05,6\end{array}$ & $\begin{array}{r}\operatorname{ad} 42,3 \pm 1,5 \\
50,0 \pm 2,4 \\
46,8 \pm 2,2 \\
47,6 \pm 4,2\end{array}$ & $\begin{array}{r}e, 12 \pm 0,16 \\
4,01 \pm 0,21 \\
4,43 \pm 0,37 \\
4,67 \pm 0,07\end{array}$ \\
\hline 17 & $\begin{array}{ll}306 & A \\
323 & B \\
340 & C \\
357 & D\end{array}$ & $\begin{array}{l}177,0 \pm 4,2 \\
181,0 \pm 1,2 \\
180,0 \pm 3,7 \\
182,5 \pm 2,1\end{array}$ & $\begin{array}{l}120,8 \pm 10,2 \\
124,9 \pm 08,1 \\
132,3 \pm 13,2 \\
129,7 \pm 14,0\end{array}$ & $\begin{array}{l}46,0 \pm 2,8 \\
50,2 \pm 2,4 \\
50,1 \pm 3,6 \\
53,0 \pm 1,4\end{array}$ & $\begin{array}{l}3,98 \pm 0,12 \\
4,16 \pm 0,29 \\
4,21 \pm 0,28 \\
4,03 \pm 0,31\end{array}$ \\
\hline
\end{tabular}


Blood lactate concentration

$\mathrm{V}_{\mathrm{E}} / \mathrm{NO}_{2}$ (mmol.1 $1^{-1}$ )

$$
\begin{array}{r}
\text { abc1, } 1,04 \pm 0,04 \\
0,99 \pm 0,04 \\
1,02 \pm 0,03 \\
1,02 \pm 0,03 \\
1,01 \pm 0,04 \\
1,00 \pm 0,04 \\
1,01 \pm 0,04 \\
1,02 \pm 0,04 \\
1,00 \pm 0,02 \\
1,02 \pm 0,02 \\
1,01 \pm 0,02 \\
1,02 \pm 0,04 \\
0,99 \pm 0,02 \\
1,00 \pm 0,05 \\
1,01 \pm 0,02 \\
1,03 \pm 0,02 \\
1,00 \pm 0,02 \\
1,04 \pm 0,02 \\
1,05
\end{array}
$$

$1,00 \pm 0,05$

$1,01 \pm 0,04$

$1,02 \pm 0,03$

$1,01 \pm 0,02$

$0,99 \pm 0,02$

$0,99 \pm 0,01$

$1,01 \pm 0,03$

$0,99 \pm 0,02$

$1,01 \pm 0,03$

$0,99 \pm 0,05$

$1,00 \pm 0,04$

$0,99 \pm 0,01$

$0,99 \pm 0,02$

$0,99 \pm 0,03$

$0,99 \pm 0,02$

$1,01 \pm 0,02$

$1,00 \pm 0,05$

1,01

$0,99 \pm 0,03$

$0,98 \pm 0,02$

$1,00 \pm 0,02$

$0,99 \pm 0,03$

0,98

$0,99 \pm 0,03$

$1,01 \pm 0,02$

$1,01 \pm 0,04$ abca $7,30,1 \pm 0,030$

$7,25.5 \pm 0,028$

$7,23.4 \pm 0,022$

$7,21 \cdot 6 \pm 0,011$

$7,21.1 \pm 0,030$

$7,19.8 \pm 0,031$

$7,18.9 \pm 0,035$

$7,17.3 \pm 0,021$

$7,19.2 \pm 0,022$

$7,18.6 \pm 0,037$

$7,16.6 \pm 0,018$

$7,26.6 \pm 0,063$

$7,28.9 \pm 0,044$

$7,26.2 \pm 0,032$

$7,37.7 \pm 0,058$

$7,29.7 \pm 0,051$

$7,27.2 \pm 0,023$

$7,25.4 \pm 0,051$

$7,20.7$

$7,21.1 \pm 0,021$

$7,19.5 \pm 0,047$

$7,16.8 \pm 0,058$

$7,16.0$

a $7,23.3 \pm 0,021$

$7,26.6 \pm 0,017$

$7,25.2 \pm 0,040$

$7,23.9 \pm 0,048$

$7,29.0 \pm 0,042$

$7,29.0 \pm 0,014$

$7,28.7 \pm 0,031$

$7,24.3$

c7, $21.6 \pm 0,020$

$7,19.7 \pm 0,041$

$7,21.6 \pm 0,030$

$7,19.6 \pm 0,023$

$7,17.6 \pm 0,028$

$7,15.6$

$7,18.7 \pm 0,028$

$7,20.2 \pm 0,021$

$7,19.6 \pm 0,032$

$7,16.7 \pm 0,021$

$7,22.8 \pm 0,041$

$7,22.7 \pm 0,023$

$7,20.9 \pm 0,055$

$7,16.7 \pm 0,022$

$$
\begin{aligned}
& \text { bcd } 9,03 \pm 1,80 \\
& 10,57 \pm 2,06 \\
& 11,89 \pm 2,06 \\
& 13,02 \pm 0,63 \\
& \text { abcd10,27 } \pm 0,06 \\
& 12,47 \pm 1,91 \\
& 13,20 \pm 1,72 \\
& 14,10 \pm 1,91 \\
& 12,95 \pm 0,93 \\
& 14,04 \pm 1,78 \\
& 14,76 \pm 2,03 \\
& 11,10 \pm 4,92 \\
& 11,05 \pm 2,29 \\
& 11,04 \pm 0,65 \\
& 7,91 \pm 2,41 \\
& 9,75 \pm 3,05 \\
& 10,83 \pm 2,28 \\
& 11,26 \pm 3,14 \\
& 11,62
\end{aligned}
$$$$
\text { bd } 10,32 \pm 1,31
$$$$
10,60 \pm 1,31
$$$$
12,77 \pm 1,32
$$$$
11,25 \pm 1,34
$$$$
11,20 \pm 0,78
$$$$
11,13 \pm 1,16
$$$$
11,59 \pm 1,55
$$$$
11,91 \pm 1,69
$$$$
9,34 \pm 0,95
$$$$
10,10 \pm 2,15
$$$$
10,77 \pm 0,76
$$$$
12,44
$$$$
14,77 \pm 0,97
$$$$
14,56 \pm 0,69
$$$$
14,96 \pm 1,34
$$$$
16,90 \pm 1,92
$$$$
17,66 \pm 1,10
$$$$
16,36
$$$$
16,29 \pm 0,85
$$$$
14,35 \pm 0,89
$$$$
14,95 \pm 1,20
$$$$
16,04 \pm 1,47
$$$$
13,25 \pm 0,12
$$$$
14,15 \pm 1,18
$$$$
14,58 \pm 2,12
$$$$
15,77 \pm 0,72
$$

$32,0 \pm 1,3$

$30,4 \pm 1,3$

$30,0 \pm 1,4$

$32,6 \pm 0,8$

$28,7 \pm 3,4$

$27,6 \pm 2,1$

$27,6 \pm 1,9$

$28,7 \pm 1,1$

$36,6 \pm 2,5$

$30,7 \pm 4,4$

$33,2 \pm 5,9$

$36,7 \pm 3,5$

$35,8 \pm 2,9$

$36,2 \pm 2,3$

$35,2 \pm 0,8$

$36,5 \pm 1,2$

$34,5 \pm 2,6$

$37,4 \pm 2,8$

$36,8 \pm 2,2$

$31,6 \pm 1,8$

$33,7 \pm 2,8$

$33,2 \pm 1,8$

27,6

$34,7 \pm 2,7$

$35,4 \pm 1,7$

$35,1 \pm 1,5$

$34,0 \pm 2,6$

$32,0 \pm 1,9$

$33,5 \pm 2,7$

$33,3 \pm 3,4$

$34,6 \pm 3,5$

$36,1 \pm 0,5$

$36,2 \pm 1,5$

$37,7 \pm 4,2$

$37,0 \pm 2,4$

$37,6 \pm 2,4$

37,8

$32,4 \pm 0,8$

$36,3 \pm 1,8$

$34,7 \pm 0,8$

$31,1 \pm 1,6$

$32,9 \pm 3,7$

$32,3 \pm 1,8$

$34,0 \pm 3,5$

$34,6 \pm 1,3$ 
TABLE A2 (COMTINUED) FEMALES

\begin{tabular}{|c|c|c|c|c|c|}
\hline $\begin{array}{l}\text { subj. } \\
\text { nr. }\end{array}$ & $\begin{array}{l}\text { Whax } \\
\text { (Watt) }\end{array}$ & $\begin{array}{l}\text { Heart rate } \\
\text { (beats } \text { min }^{-1} \text { ) }\end{array}$ & (Fstent) & $\begin{array}{l}\text { Respiratory } \\
\text { rate } \\
\left(\mathrm{min}^{-1}\right)\end{array}$ & $\begin{array}{l}\text { vomax } \\
\left(1 \mathrm{~min}^{-1}\right)\end{array}$ \\
\hline \multirow[t]{3}{*}{3} & $190 \mathrm{~A}$ & $185,5 \pm 2,6$ & $69,3 \pm 4,8$ & $52,7 \pm 2,7$ & $2,46 \pm 0,22$ \\
\hline & $200 \mathrm{~B}$ & $186,2 \pm 2,6$ & $72,3 \pm 4,9$ & $53,6 \pm 2,1$ & $2,48 \pm 0,18$ \\
\hline & $210 \mathrm{C}$ & $185,5 \pm 1,7$ & $78,1 \pm 6,0$ & $55,8 \pm 5,7$ & $2,65 \pm 0,16$ \\
\hline \multirow[t]{4}{*}{4} & $160 \mathrm{~A}$ & $183,8 \pm 2,2$ & $79,6 \pm 3,5$ & $49,8 \pm 2,4$ & $2,72 \pm 0,22$ \\
\hline & $170 \mathrm{~B}$ & $185,1 \pm 2,6$ & $80,4 \pm 6,5$ & $51,1 \pm 3,9$ & $2,37 \pm 0,21$ \\
\hline & $180 \mathrm{C}$ & $183,6 \pm 4,6$ & $80,4 \pm 7,4$ & $50,8 \pm 7,0$ & $2,26 \pm 0,17$ \\
\hline & 1900 & $185,6 \pm 5,0$ & $84,9 \pm 5,6$ & $52,3 \pm 2,5$ & $2,35 \pm 0,21$ \\
\hline \multirow[t]{3}{*}{5} & $190 \mathrm{~A}$ & $182,6 \pm 2,3$ & $64,0 \pm 11,8$ & $44,5 \pm 3,0$ & $\mathrm{a} 2,70 \pm 0,25$ \\
\hline & $200 B$ & $186,9 \pm 3,4$ & $62,8 \pm 5,7$ & $44,4 \pm 2,3$ & $2,62 \pm 0,18$ \\
\hline & $210 \mathrm{C}$ & $192,0 \pm 2,0$ & 69,0 & $39,3 \pm 1,7$ & 2,59 \\
\hline \multirow[t]{3}{*}{6} & $140 \mathrm{~A}$ & $182,5 \pm 3,6$ & $70,5 \pm 5,1$ & $39,0 \pm 3,7$ & $a b 1,99 \pm 0,27$ \\
\hline & $150 \mathrm{~B}$ & $183,2 \pm 3,2$ & $74,2 \pm 7,0$ & $40,6 \pm 3,1$ & $2,29 \pm 0,15$ \\
\hline & $160 \mathrm{C}$ & $183,7 \pm 2,8$ & $74,9 \pm 3,1$ & $41,7 \pm 2,7$ & $2,34 \pm 0,10$ \\
\hline \multirow[t]{5}{*}{11} & $170 \mathrm{~A}$ & 183,0 & 76,4 & 44 & $\mathrm{~d} 2,71$ \\
\hline & $180 \mathrm{~B}$ & $186,0 \pm 1,7$ & $77,1 \pm 5,1$ & $48,6 \pm 4,1$ & $2,65 \pm 0,06$ \\
\hline & $190 \mathrm{C}$ & $187,5 \pm 2,8$ & $80,6 \pm 5,5$ & $50,0 \pm 3,9$ & $2,67 \pm 0,17$ \\
\hline & $200 \mathrm{D}$ & $184,5 \pm 2,0$ & $84,0 \pm 3,3$ & $51,7 \pm 3,6$ & $2,83 \pm 0,13$ \\
\hline & $210 E$ & $185,4 \pm 2,0$ & $84,3 \pm 8,6$ & $46,4 \pm 3,9$ & $2,95 \pm 0,10$ \\
\hline \multirow[t]{4}{*}{15} & $160 \mathrm{~A}$ & $184,0 \pm 2,3$ & $60,4 \pm 0,7$ & $32,1 \pm 1,2$ & $2,30 \pm 0,17$ \\
\hline & $170 \mathrm{~B}$ & $182,7 \pm 2,0$ & $65,9 \pm 4,0$ & $34,5 \pm 3,0$ & $2,34 \pm 0,20$ \\
\hline & $180 \mathrm{C}$ & $185,6 \pm 5,0$ & $69,1 \pm 8,3$ & $33,6 \pm 6,6$ & $2,50 \pm 0,09$ \\
\hline & $190 \mathrm{D}$ & $181,5 \pm 2,1$ & 63,0 & 36,2 & 2,47 \\
\hline \multirow[t]{4}{*}{18} & $216 \mathrm{~A}$ & 188 & 83,6 & & 2,93 \\
\hline & $228 B$ & $185,2 \pm 3,2$ & $99,1 \pm 8,5$ & $55,5 \pm 3,7$ & $3,01 \pm 0,22$ \\
\hline & $240 \mathrm{C}$ & $184,7 \pm 3,0$ & $99,9 \pm 6,4$ & $55,6 \pm 2,5$ & $3,15 \pm 0,20$ \\
\hline & 2520 & $185,6 \pm 0,5$ & $105,9 \pm 8,8$ & $57,0 \pm 3,6$ & $3,26 \pm 0,05$ \\
\hline \multirow[t]{4}{*}{19} & $190 \mathrm{~A}$ & $184,3 \pm 4,5$ & $73,5 \pm 10,2$ & $38,1 \pm 5,8$ & $2,57 \pm 0,12$ \\
\hline & $200 \mathrm{~B}$ & $179,2 \pm 4,9$ & $70,4 \pm 8,3$ & $39,1 \pm 2,7$ & $2,53 \pm 0,14$ \\
\hline & $210 \mathrm{C}$ & $178,1 \pm 6,4$ & $82,8 \pm 3,2$ & $43,2 \pm 1,6$ & $2,67 \pm 0,11$ \\
\hline & $220 \mathrm{D}$ & 178 & 84,7 & 46,0 & 2,70 \\
\hline
\end{tabular}

single numbers without sd refer to only one measurement a means $p<0.05$ between hmax values $A$ and $B$

$b$ means $p<0.05$ between Whax values $A$ and $C$ $c$ means $p<0.05$ between thax values $A$ and $D$ $d$ means $p<0.05$ between whax values $B$ and $C$ e means $p<0.05$ between whax values $B$ and $D$ 
R

Blood pH

, $00 \pm 0,03$

$1,01 \pm 0,03$

$1,03 \pm 0,03$

$1,22 \pm 0,04$

$1,05 \pm 0,03$

$1,08 \pm 0,03$

$1,08 \pm 0,03$

$1,01 \pm 0,01$

$1,03 \pm 0,02$

$1,04 \pm 0,02$

$1,03 \pm 0,03$

$1,01 \pm 0,04$

$1,04 \pm 0,02$

0,99

$1,00 \pm 0,03$

$1,01 \pm 0,03$

$1,00 \pm 0,04$

$0,9 y \pm 0,04$

$1,03 \pm 0,01$

$1,00 \pm 0,02$

$0,99 \pm 0,03$

0,99

0,99

$0,99 \pm 0,03$

$1,00 \pm 0,04$

$1,00 \pm 0,04$

$0,99 \pm 0,03$

$0,99 \pm 0,04$

$1,01 \pm 0,03$ ab7, 21.1 10,011

$7,18.2 \pm 0,032$

$7,16.9 \pm 0,021$

$7,19.4 \pm 0,033$

$7,18.4 \pm 0,021$

$7,16.5 \pm 0,043$

$7,15.5 \pm 0,042$

$7,29.4 \pm 0,031$

$7,23.5 \pm 0,043$

$7,22.9 \pm 0,027$

$7,24.8 \pm 0,030$

$7,25.1 \pm 0,046$

$7,24.8+0,041$

$7,23.6$

$7,22.0 \pm 0,021$

$7,21 \cdot 7 \pm 0,032$

$7,21.7 \pm 0,044$

$7,26.8 \pm 0,033$

ac $7,18.3 \pm 0,029$

$7,25.4 \pm 0,029$

$7,18.9 \pm 0,046$

$7,23.7 \pm 0,021$

$7,21.0$

$7,20.7 \pm 0,034$

$7,19.9 \pm 0,021$

$7,20,2 \pm 0,043$

$7,27.8 \pm 0,038$

$7,28.1 \pm 0,021$

$7,27.9 \pm 0,025$

$7,28.3$
Blood lactate concentration (mol. $)^{-1}$ )

$\mathrm{V}_{\mathrm{E}} \mathrm{NO}_{2}$

$10,71 \pm 1,77$

$12,03 \pm 1,18$

$12,25 \pm 1,61$

$11,62 \pm 2,21$

$12,20 \pm 1,57$

$10,74 \pm 1,73$

$12,71 \pm 1,86$

a $6,10 \pm 1,39$

$7,92 \pm 1,58$

$8,38 \pm 1,13$

b $9,75 \pm 1,58$

$10,95 \pm 1,44$

$11,47 \pm 0,90$

14,84

$11,35 \pm 0,46$

$13,79 \pm 1,76$

$13,69 \pm 1,47$

$12,28 \pm 1,73$

c $0,86 \pm 0,14$

$9,83 \pm 0,70$

$9,42 \pm 1,64$

$10,32 \pm 0,19$

13,52

$14,39 \pm 1,73$

$15,27 \pm 2,39$

$14,06 \pm 1,13$

$10,79 \pm 1,59$

$9,33 \pm 1,67$

$9,43 \pm 1,48$

9,48
$34,2 \pm 2,7$

$35,1 \pm 2,4$

$35,7 \pm 2,6$

$43,0 \pm 4,6$

$41,2 \pm 3,5$

$43,1 \pm 4,5$

$43,8 \pm 1,2$

$32,4 \pm 1,7$

$29,6 \pm 2,7$

32,2

$43,3 \pm 6,0$

$39,2 \pm 2,3$

$38,6 \pm 1,5$

34,1

$35,1 \pm 2,6$

$36,5 \pm 3,4$

$35,9 \pm 1,6$

$34,6 \pm 3,5$

$31,3 \pm 1,8$

$30,3+2,5$

$31,5 \pm 2,0$

30,8

34,5

$36,2 \pm 2,0$

$35,4 \pm 1,4$

$35,9 \pm 3,3$

$29,8 \pm 3,8$

$30,0 \pm 2,3$

$32,5 \pm 1,1$

32,5 
THBLE AS MLES

Comparison between predicted and measured $\mathrm{Vu}$ max in male and female subjects. In each subject the experiments are grouped according to the whax attained. The mean values and standard deviations are presented.

\begin{tabular}{|c|c|c|c|c|}
\hline & $\begin{array}{l}\text { medsured } \\
\text { bo max } \\
\left(12 \min ^{-1}\right)\end{array}$ & $\begin{array}{l}\text { mean predicted } \\
\text { romax } \\
\left(12^{2} \min ^{-1}\right)\end{array}$ & $\mathrm{n}$ & $\begin{array}{l}q \text { difference } \\
\text { of predicted } \\
\text { minus } \\
\text { measured } \\
\text { Vo } 2^{\text {max }} \\
\end{array}$ \\
\hline \multicolumn{5}{|l|}{ Subjectnr.2 } \\
\hline Wma $x=2854$ & $3,78 \pm 0,30$ & $3,95 \pm 0,05$ & 4 & $+4,49 \%$ \\
\hline Whata $x=300 \mathrm{w}$ & $3,96 \pm 0,29$ & $4,25 \pm 0,23$ & 26 & $+7,32 \%$ \\
\hline $\min a x=315 \mathrm{k}$ & $4,08 \pm 0,23$ & $4,44 \pm 0,22$ & 30 & $+8,82 \%$ \\
\hline Wha $x=330 \mathrm{w}$ & $4,20 \pm 0,28$ & $4,47 \pm 0,25$ & 11 & $+6,436$ \\
\hline $\begin{array}{l}\text { sub jectenr. } \\
\text { Wma } x=216 \mathrm{~W}\end{array}$ & $2,74 \pm 0,36$ & $2,85 \pm 0,04$ & 3 & $+4,01 \%$ \\
\hline Wha $x=228 \mathrm{~W}$ & $3,08 \pm 0,25$ & $3,06 \pm 0,12$ & 15 & $-0,65 \%$ \\
\hline Wmax $=240 \mathrm{~W}$ & $2,89 \pm 0,35$ & $3,01 \pm 0,16$ & 4 & $+4,15 \%$ \\
\hline \multicolumn{5}{|l|}{ subjectnr. 8} \\
\hline Wmax $=238 \mathrm{w}$ & $2,93 \pm 0,21$ & $3,16 \pm 0,22$ & 5 & $+7,85$ \\
\hline wha $x=250 \mathrm{w}$ & $3,43 \pm 0,37$ & $3,24 \pm 0,32$ & 6 & $-5,54 \%$ \\
\hline Whax $=263 \mathrm{~W}$ & $3,32+0,28$ & $3,46 \pm 0,33$ & 8 & $+4,22 \%$ \\
\hline \multicolumn{5}{|l|}{ subjectnr.9 } \\
\hline$W \max =252 \mathrm{~W}$ & $3,40 \pm 0,24$ & $3,42 \pm 0,34$ & 2 & $+0,58 \%$ \\
\hline Wha $x=266 \mathrm{~W}$ & $3,64 \pm 0,30$ & $3,49 \pm 0,35$ & 8 & $-4,12 \%$ \\
\hline Wmax $=280 \mathrm{~W}$ & $3,79 \pm 0,26$ & $3,68 \pm 0,25$ & 4 & $-2,90 \%$ \\
\hline Wha $x=294 \mathrm{~W}$ & 3,72 & 3,90 & 1 & $+4,83 \%$ \\
\hline \multicolumn{5}{|l|}{ subjectnr.10 } \\
\hline Wmax $=255 \mathrm{~W}$ & $3,76 \pm 0,17$ & $3,38 \pm 0,14$ & 8 & $-10,11 \%$ \\
\hline Wha $x=270$ w & $3,76 \pm 0,26$ & $3,48 \pm 0,20$ & 9 & $-7,45 \%$ \\
\hline Wmax $=285 \mathrm{~W}$ & $4,00 \pm 0,20$ & $3,62 \pm 0,20$ & 4 & $-9,50 \%$ \\
\hline Wha $x=300 \mathrm{~W}$ & $4,43 \pm 0,10$ & $3,74 \pm 0,00$ & 2 & $-15,58 \%$ \\
\hline \multicolumn{5}{|l|}{ subjectnr. 12} \\
\hline Wmax= $266 \mathrm{~W}$ & $3,82 \pm 0,23$ & $3,68 \pm 0,20$ & 4 & $-3,66 \%$ \\
\hline Wma $x=280 \mathrm{~W}$ & $3,94 \pm 0,14$ & $3,67 \pm 0,10$ & 5 & $-6,85 \%$ \\
\hline Wrax $=294 \mathrm{~W}$ & $4,16 \pm 0,23$ & $3,75 \pm 0,21$ & 8 & $-9,86 \%$ \\
\hline Whax $=3084$ & $4,36 \pm 0,17$ & $4,08 \pm 0,38$ & 4 & $-6,42 \%$ \\
\hline \multicolumn{5}{|l|}{ subjectnr. 13} \\
\hline Wmax $=225 \mathrm{~W}$ & $2,74 \pm 0,28$ & $3,17 \pm 0,15$ & 4 & $+15,69 \%$ \\
\hline Wha $x=238 \mathrm{~W}$ & $2,85 \pm 0,36$ & $3,19 \pm 0,21$ & 13 & $+11,92 \%$ \\
\hline Wmax=250W & $2,94 \pm 0,36$ & $3,37 \pm 0,09$ & 5 & $+14,63 \%$ \\
\hline Wha $x=263 \mathrm{~N}$ & $2,80 \pm 0,17$ & $3,33 \pm 0,11$ & 2 & $+18,93 \%$ \\
\hline \multicolumn{5}{|l|}{ subjectnr. 16} \\
\hline Wma $x=300 \mathrm{~W}$ & $4,12 \pm 0,16$ & $4,06 \pm 0,00$ & 3 & $-1,46 \%$ \\
\hline Wha $x=315 \mathrm{~W}$ & $4,01 \pm 0,21$ & $3,9010,24$ & 8 & $-2,74 \%$ \\
\hline Whax $=330 \mathrm{w}$ & $4,43 \pm 0,37$ & $3,90 \pm 0,28$ & 6 & $-8,35 \%$ \\
\hline Wha $x=345 \mathrm{~W}$ & $4,67 \pm 0,07$ & $4,47 \pm 0,26$ & 7 & $-4,28 \%$ \\
\hline \multicolumn{5}{|l|}{ subjectnr. 17} \\
\hline Wmax=306W & $3,98 \pm 0,12$ & $4,48 \pm 0,30$ & 2 & $+12,56 \%$ \\
\hline Wha $x=323 \mathrm{~W}$ & $4,16 \pm 0,29$ & $4,16 \pm 0,18$ & $\overline{6}$ & $0,00 \%$ \\
\hline Wmax $=340 \mathrm{~W}$ & $4,21 \pm 0,28$ & $4,79 \pm 0,68$ & 8 & $+13,77 \%$ \\
\hline Wria $x=357 \mathrm{~W}$ & $4,03 \pm 0,31$ & $4,62 \pm 0,00$ & 2 & $+14,14 \%$ \\
\hline
\end{tabular}


TABLE A3 (CONTINUEO) FEMALES

measured

$\left(12^{\min } \min ^{-1}\right)$ predicted

vo. $\max$

$\left(1 \min ^{-1}\right)$ n

difference of predicted minus

measured $\mathrm{VO}_{2}$ $\max$
Subjectnr. 3

Wmax $=190 \mathrm{~W}$

Wha $x=200 \mathrm{~W}$

Whax $=210 \mathrm{~W}$

subjectnr. 4

Wmax $=170 \mathrm{~W}$

Wha $x=180 \mathrm{~W}$

Wmax $=190 \mathrm{~W}$

subjectnr. 5

Wmax $=190 \mathrm{~W}$

Wha $x=200 \mathrm{~W}$

Wmax $=210 \mathrm{~W}$

subjectnr. 6

wmax $=140 \mathrm{~W}$

Wma $x=150 \mathrm{~W}$

Wma $x=160 \mathrm{~W}$

s.ubjectnr. 11

Wmax $=180 \mathrm{~W}$

Wma $x=190 \mathrm{~W}$

Wmax $=200 \mathrm{~W}$

Wma $x=210 \mathrm{~W}$

subjectnr. 15

Wmax $=160 \mathrm{~W}$

Wma $x=170 \mathrm{~W}$

Wma $x=180 \mathrm{~W}$

Wha $x=190 \mathrm{~W}$

subjectnr. 18

Wha $x=216 \mathrm{~W}$

Whax $=228 \mathrm{~W}$

Wmax $=240 \mathrm{~W}$

Wha $x=252 w$

subjectnr.19

Wima $x=190 \mathrm{~W}$

Wha $x=200 \mathrm{~W}$

Wina $x=210 \mathrm{~W}$

Wha $x=220 \mathrm{~W}$
$2,46 \pm 0,22$

$2,48 \pm 0,18$

$2,65 \pm 0,16$

$2,37 \pm 0,21$

$2,26 \pm 0,17$

$2,35 \pm 0,21$

$2,70 \pm 0,25$

$2,62 \pm 0,18$

2,59

$1,99 \pm 0,27$

$2,29 \pm 0,15$

$2,34 \pm 0,10$

$2,65 \pm 0,06$

$2,67 \pm 0,17$

$2,83 \pm 0,13$

$2,95 \pm 0,10$

$2,30 \pm 0,17$

$2,34 \pm 0,20$

$2,50 \pm 0,09$

2,47

2,93

$3,01 \pm 0,22$

$3,15 \pm 0,20$

$3,26 \pm 0,05$

$2,57 \pm 0,12$

$2,53 \pm 0,14$

$2,67 \pm 0,11$

2,70
$2,40 \pm 0,05$

2, $49 \pm 0,08$

$2,52 \pm 0,09$

$2,17 \pm 0,13$

$2,66 \pm 0,29$

$2,38 \pm 0,04$

$2,75 \pm 0,14$

$2,75 \pm 0,20$

$2,78 \pm 0,09$

$2,07 \pm 0,20$

$2,18 \pm 0,21$

$2,24 \pm 0,24$

$2,18 \pm 0,02$

$2,37 \pm 0,10$

$2,36 \pm 0,11$

$2,47 \pm 0,19$

$2,18 \pm 0,09$

$2,44 \pm 0,14$

$2,40 \pm 0,20$

$2,73 \pm 0,00$

2,94

$2,94 \pm 0,13$

$3,06 \pm 0,19$

$3,20 \pm 0,32$

$2,47 \pm 0,22$

$2,90 \pm 0,22$

$2,90 \pm 0,36$

3,23
$-2,44 \%$

$0,00 \%$

$-4,91 \%$

$-8,44 \%$

$+17,70 \%$

$+1,28 \%$

$+1,85 \%$

$+4,96 \%$

$+7,34 \%$

$+4,02 \%$

$-3,93 \%$

$-4,27 \%$

$-17,74 \%$

$-11,24 \%$

$-16,61 \%$

$-16,27 \%$

$-5,21 \%$

$-4,27 \%$

$-4,00 \%$

$+10,53 \%$

$0,00 \%$

$-2,33 \%$

$-2,86 \%$

$-1,84 \%$

$-3,89 \%$

$-14,62 \%$

$-8,61 \%$

$+19,63 \%$ 
TABLE A4

Absolute and relative workload at which the mean blood lactate concentration amounts to 4 mol. $\}^{-1}$. In each subject the experiments are grouped according to the wax actained.

\begin{tabular}{|c|c|c|c|}
\hline subjectnr. & $\begin{array}{l}\text { Whax } \\
\text { (Watt) }\end{array}$ & $\begin{array}{l}\text { worklaad at mean } \\
\text { blaod lactate con- } \\
\text { centratjon of } 4 \\
\text { mol. } \text { (Watt) }^{-1} \text { (What }\end{array}$ & $\begin{array}{l}\text { rellative work- } \\
\text { load at lactate } \\
\text { concentration } \\
\text { of } 4 \text { mno } 1.1^{-1}\end{array}$ \\
\hline
\end{tabular}

MALES

1

2

8

9

10

13

16

151

495

472

450

330

315

300

263

250

238

308

266

285

270

255

250

238

225

345

330

315

FEMALES

3

4

5

19
210

200

190

190

180

210

200

190

220

210

200
393

390

383

390

225

230

210

198

191

180

212

200

192

199

203

188

181

173

221

215

208
$76 \%$

$79 \%$

$81 \%$

$87 \%$

$71 \%$

$73 \%$

$70 \%$

$75 \%$

$76 \%$

$76 \%$

$69 \%$

$75 \%$

674

$74 \%$

$80 \%$

$75 \%$

$76 \%$

$77 \%$

$64 \%$

$65 \%$

$66 \%$
152

149

145

127

123

180

177

171

153

150

145
$72 \%$

$75 \%$

$76 \%$

$67 \%$

$68 \%$

$85 \%$

$83 \%$

$90 \%$

$70 \%$

$71 \%$

$72 \%$ 
TABLE A5

Scores of the subjective feelings of distress at the moment of exhaustion. The experiments in each subject are grouped according to the whax attained. The means and standard deviations are shown.

\begin{tabular}{|c|c|c|c|c|c|c|}
\hline s. & $\begin{array}{l}\text { Whax } \\
\text { (Watt) }\end{array}$ & $\begin{array}{l}\text { General } \\
\text { fatigue }\end{array}$ & $\begin{array}{l}\text { Respirata- } \\
\text { ry stress }\end{array}$ & $\begin{array}{l}\text { muscle } \\
\text { pain }\end{array}$ & $\begin{array}{l}\text { decrease } \\
\text { of strength }\end{array}$ & $n$ \\
\hline \multirow[t]{4}{*}{1} & 450 & $8,2 \pm 0,3$ & $8,7 \pm 1,6$ & $7,8 \pm 1,3$ & $8,1 \pm 0,6$ & 7 \\
\hline & 472 & $8,5 \pm 0,6$ & $8,9 \pm 0,3$ & $7,4 \pm 1,3$ & $8,2+0,6$ & 10 \\
\hline & 495 & $8,5 \pm 1,2$ & $8,6 \pm 0,4$ & $7,2 \pm 1,1$ & $8,0 \pm 1,1$ & 14 \\
\hline & 517 & $8,4 \pm 0,4$ & $9,0 \pm 0,0$ & $7,0 \pm 0,0$ & $8,0 \pm 1,0$ & 3 \\
\hline \multirow[t]{2}{*}{3} & 200 & $8,3 \pm 0,5$ & $7,0 \pm 1,9$ & $4,4 \pm 1,3$ & $6,6 \pm 1,4$ & 11 \\
\hline & 210 & $8,8 \pm 0,3$ & $8,0 \pm 0,5$ & $3,7 \pm 1,7$ & $7,0 \pm 1,2$ & 7 \\
\hline \multirow[t]{4}{*}{4} & 160 & 8 & & 0 & 8 & 1 \\
\hline & 170 & $8,2 \pm 0,8$ & $4,9 \pm 1,9$ & 0 & $8,5 \pm 0,7$ & 8 \\
\hline & 180 & $8,7 \pm 0,8$ & $4,5 \pm 2,6$ & 0 & $8,0 \pm 0,8$ & 4 \\
\hline & 190 & $9,0 \pm 0,0$ & $8,5 \pm 0,7$ & 0 & $7,0 \pm 0,0$ & 2 \\
\hline \multirow[t]{3}{*}{5} & 190 & $8,5 \pm 1$ & $7,7 \pm 0,9$ & 0 & $8,6 \pm 0,5$ & 4 \\
\hline & 200 & $8,1 \pm 0,8$ & $7,8 \pm 1,3$ & 0 & $7,2 \pm 1,6$ & 10 \\
\hline & 210 & $8,0 \pm 0,0$ & $8,3 \pm 0,5$ & 0 & $2,6 \pm 3,0$ & 3 \\
\hline \multirow[t]{3}{*}{6} & 140 & $8,4 \pm 0,5$ & $7,2 \pm 1,1$ & 0 & $10,0 \pm 0,0$ & 6 \\
\hline & 150 & $8,2 \pm 0,7$ & $5,2 \pm 1,3$ & 0 & $10,0 \pm 0,5$ & 7 \\
\hline & 160 & $10,0 \pm 0,0$ & $8,5 \pm 0,7$ & 0 & $10,0 \pm 0,3$ & 2 \\
\hline \multirow[t]{3}{*}{7} & 216 & 9 & 7 & 9 & 9 & 1 \\
\hline & 228 & $9,0 \pm 0,7$ & $7,9 \pm 1,5$ & $7,7 \pm 1,3$ & $9,5 \pm 0,15$ & 15 \\
\hline & 240 & $10,0 \pm 0$ & $9,3 \pm 0,5$ & $4,6 \pm 1,5$ & $10,0 \pm 0,0$ & 3 \\
\hline \multirow[t]{3}{*}{8} & 238 & $8,3 \pm 0,5$ & 0 & $8,0 \pm 0,0$ & $9,0 \pm 0,0$ & 3 \\
\hline & 250 & $9,0 \pm 0,8$ & 0 & $8,3 \pm 0,9$ & $9,7 \pm 0,5$ & 4 \\
\hline & 263 & $8,2 \pm 1,1$ & 0 & $8,3 \pm 1,5$ & $9,5 \pm 0,8$ & 5 \\
\hline \multirow[t]{4}{*}{9} & 252 & $8,0 \pm 1,4$ & $7,5 \pm 2,0$ & $7,5 \pm 0,7$ & $8,5 \pm 0,5$ & 2 \\
\hline & 266 & $8,2 \pm 1,5$ & $7,2 \pm 1,2$ & $5,7 \pm 2,6$ & $8,7 \pm 0,5$ & 4 \\
\hline & 280 & $8,5 \pm 1,0$ & $7,3 \pm 1,0$ & $3,6 \pm 2,9$ & $7,3 \pm 0,8$ & 6 \\
\hline & 294 & $9,0 \pm 1,4$ & $8,0 \pm 1,4$ & $3,0 \pm 1,4$ & $8,5 \pm 0,5$ & 2 \\
\hline \multirow[t]{3}{*}{10} & 255 & $8,5 \pm 0,8$ & $6,6 \pm 1,5$ & $8,1 \pm 3,6$ & $7,5 \pm 3,7$ & 6 \\
\hline & 270 & $8,5 \pm 0,8$ & $7,1 \pm 2,8$ & $8,0 \pm 2,4$ & $9,0 \pm 0,5$ & 7 \\
\hline & 285 & 10 & 9 & 1 & 10 & 1 \\
\hline \multirow[t]{5}{*}{11} & 170 & 9 & 7 & 5 & 9 & 1 \\
\hline & 180 & $9,0 \pm 0,8$ & $6,7 \pm 0,5$ & $3,0 \pm 3,5$ & $8,7 \pm 0,5$ & 3 \\
\hline & 190 & $9,0 \pm 0,5$ & $6,7 \pm 1,8$ & $1,1 \pm 2,0$ & $8,8 \pm 0,3$ & 6 \\
\hline & 200 & $9,0 \pm 0,0$ & $8,2 \pm 0,9$ & $2,5+3,1$ & $9,0 \pm 0,0$ & 6 \\
\hline & 210 & $9,0 \pm 0,0$ & $7,3 \pm 0,5$ & 0 & 9 & 3 \\
\hline \multirow[t]{4}{*}{12} & 266 & $8,6 \pm 0,5$ & $8,0 \pm 0,0$ & 0 & $9,0 \pm 0,0$ & 3 \\
\hline & 280 & $9,0 \pm 0,7$ & $7,2 \pm 1,3$ & $8,1 \pm 1,2$ & $8,4 \pm 1,3$ & 5 \\
\hline & 294 & $8,8 \pm 0,4$ & $6,6 \pm 2,7$ & $8,3 \pm 0,8$ & $7,4 \pm 2,0$ & 5 \\
\hline & 308 & $9,0 \pm 0,8$ & $8,5 \pm 1,2$ & 0 & $5,0 \pm 2,4$ & 4 \\
\hline \multirow[t]{4}{*}{13} & 225 & $7,0 \pm 1,7$ & $5,3 \pm 4,0$ & $8,3 \pm 1,1$ & $9,0 \pm 1,0$ & 3 \\
\hline & 238 & $8,0 \pm 1,3$ & $6,4 \pm 2,4$ & $8,3 \pm 1,7$ & $8,3 \pm 1,7$ & 12 \\
\hline & 250 & $9,0 \pm 0,0$ & $7,4 \pm 1,6$ & $8,0 \pm 1,0$ & $8,2 \pm 0,8$ & 5 \\
\hline & 263 & $9,5 \pm 0,5$ & $8,5 \pm 0,7$ & $8,0 \pm 2,8$ & $8,0 \pm 2,8$ & 2 \\
\hline \multirow[t]{2}{*}{19} & 190 & $8,5 \pm 0,7$ & $8,5 \pm 0,7$ & $1,5 \pm 2,2$ & $9,0 \pm 1,4$ & 6 \\
\hline & 200 & $9,0 \pm 0,4$ & $8,5 \pm 0,5$ & 0 & $9,1 \pm 0,4$ & 8 \\
\hline
\end{tabular}



ATPS ambient temperature, barometric pressure and saturated with vapour

BTPS body temperature, aribient barometric pressure and saturated with wapour

CP creatine phosphate

$F_{E 02}$ fractional concentration of oxygen in expiratory air $F_{\text {ECO2 }}$ fractional concentration of carbon dioxide in expiratory air

FEN2 fractional concentration of nitrogen in expiratory air $\mathrm{F}_{\mathrm{I02}}$ fractional concentration of oxygen in inspiratory air $\mathrm{F}_{\mathrm{ICO} 2}$ fractional concentration of carbon dioxide in inspiratory air

FIN2 fractional concentration of nitrogen in inspiratory air $\checkmark$ Joule

kJ kilouloule

$\mathrm{pCO}_{2}$ partial pressure of $\mathrm{CO}_{2}$

$R$ respiratory ratio

rpin revalutions per minute

sd standard deviation

STPD standard temperature $\left(0^{\circ} \mathrm{C}\right)$, barometric pressure of 760 minty $(101,08 \mathrm{kPa})$ and $\mathrm{dry}$

$\dot{V}_{\mathrm{E}} \quad$ expiratory volume $\left(1 . \mathrm{min}^{-1}\right)$

$\dot{v}_{1} \quad$ inspiratary volume $\left(1 . \mathrm{min}^{-1}\right)$

$\mathrm{VCO}_{2}$ expired volume of $\mathrm{CO}_{2}\left(1 . \mathrm{min}^{-1}\right)$

$\mathrm{Wo}_{2}$ oxygen uptake $\left(1 \mathrm{~min}^{-1}\right)$

$\mathrm{Vu}_{2}$ max maximal oxygen uptake $\left(1 . \mathrm{min}^{-1}\right)$

W Watt $\left(1 \mathrm{~J} \cdot \mathrm{s}^{-1}\right)$

Wmax maximal workload attained (Watt) 
MAWOURU

Als pas afgestudeerd arts was het voor mij een hele uitdaging om mede inhoud en richting te kumnen geven aan het nog op te starten onderzoek aan de Rijksuniversiteit van Limburg. Boordevol, met nog weinig gestructureerde ideeen moest een nieuw laboratorium voor inspanningsfyslologie worden opgezet. Al heel snel bleek dat de opleiding tot arts geenszins een apleiding tot wetenschappelijk onderzoeker is. Naast participatie in het onderzoek dat Dr. F.T.J. Verstappen had geentameerd, tracntte ik mijn eigen richting te vinden. Na enkele moeizame jaren leidde de komst van prof.dr. W. Orukker, bij de capaciteitsgroep anatomie, de yoor mij beslissende wending in amdat nij de know how bezat on mijn ideeen tot realiteit te maken.

Aan het tot stand komen wan dit proefschrift hebben uiteindelijk verschillende mensen een bijdrage geleverd. Een heel direkte en belangrijke bijdrage leverden mijn promotor prof.dr. R.S Reneman en mijn co-promotor Dr. F.T.l. Verstappen. Beste Rob, ik ben je veel dank verschuldigd voor je schier onuitputtelijke geduld om steeds opnieuw mijn schrijfoefeningen voor dit proefschrift te corrigeren en te bespreken. Ik heb het als een groot voorrecht beschouwd am van je grate kennis en je uiterst prettige manier wan begeleiden mee te hebben kunnen profitteren. Beste Frans, als co-promotor en geestelijke vader wan het onderzoek, dat in dit praefschrift beschreven wordt, ben iik je dankbaar voor je kritische opmerkingen die veel hebben bijgedragen tot de uiteindelijke vorm van dit proefschrift. De discussies met jou heb ik altijd als zeer stimulerend ervaren.

Peter Geurten en Gerrit van Kranenburg zijn vaak de spil geweest waarom het hele onderzoek draaide. zij zorgden er voor dat de experimenten doorgang konden vimden, terwiji ze bijna al onze tekortkomingen en fouten op soepele wijze hebben opgevangen. Peter Geurten heeft daarnaast de figuren voor dit proefschrift verzorgd.

ufschoon vaak op de achtergrond, doch daaroin zeker niet minder belangrijk, waren de mensen van de mechanische werkplaats. Zij zorgden ervoor dat speciale instrumentele aanpassingen snel en vakkundig gereal iseerd werden.

De proefpersomen, die wekelijks aan een infuus werden aangesloten 
om zich vervolgens tot het witerste in te spannen ben ik grote dank verschuldigd. Zonder hun welwillendheid en motivatie had dit onderzoek niet kunnen plaatsvinden.

Voor het verwerken van de data zijn Lex Volovics en Sjef Roos een grote steun voor mij geweest. Met hun hulp werd het voor mij mogelijk gebruik te maken van de computer.

De referenten prof.dr. F. ten Hoor en prof. dr. R.A. Binkhorst ben ik dank verschuldigd voor hun nauwgezet lezen van dit proefschrift en hun vele kritische opmerkingen, die belangrijk hebben bijgedragen tot de uiteindelijke vorm.

Guus van Rooy heeft op vakkundige wijze de omslag verzorgd. Marion de Vreede is mijn reddende engel geweest bij het typen van dit proefschrift. Of schoon ik me sons bezwaard voelde als ze voor de zoveelste keer alles moest veranderen, was het werk haar nooit te veet. 


\section{CURKICULUM VITAE}

Harm Kuipers werd in 1947 in de Drentse gemeente Vries geboren. Wadat in 1968 de opleiding voor onderwijzer met het examen werd afgesloten, werd een avondopleiding voor HBS-B gevolgd. In 1970 deed hij staatsexamen $H B S-B$ en ging geneeskunde studeren aan de Rijksuniversiteit wan Groningen. Wadat in 1976 het artsexamen werd afgelegd, werkt hij vanaf 1 juli 1976 als wetenschappelijk medewerker bij de capaciteitsgroep fysiologie van de Rijksuniversiteit Limburg. Na het mede opzetten van het laboratorium voor inspanningsfysiologie heeft hij vanaf 1977 samen met Dr. F.T.J. Werstappen dan het onderzoek gewerkt, dat tot het tot stand komen van dit proefschrift heeft geleid. 